\title{
Supplemental material for Climate forcing by battered-and-breaded fillets and crab-flavored sticks from Alaska pollock
}

Author names: Brandi L. McKuin ${ }^{a^{*}}$, Jordan T. Watson ${ }^{b}$, Alan C. Haynie ${ }^{c}$, and J. Elliott Campbell ${ }^{\text {d }}$

Author affiliations:

${ }^{a}$ Sierra Nevada Research Institute, University of California, Merced, California, US

${ }^{\mathrm{b}}$ Auke Bay Laboratories, Alaska Fisheries Science Center, National Marine Fisheries Service, NOAA, Juneau, Alaska, US

${ }^{\mathrm{c}}$ Resource Ecology and Fisheries Management, Alaska Fisheries Science Center, National Marine Fisheries Service, NOAA, Seattle, Washington, US

${ }^{\mathrm{d}}$ University of California, Santa Cruz, California, US

*bmckuin@ucsc.edu 


\section{Table of Contents}

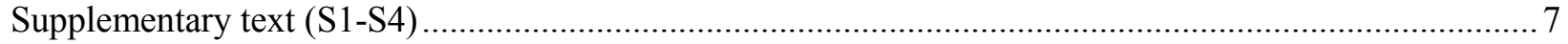

S1. Inventory of material and energy flows of the seafood supply-chain.................................................

S1.1 Fishing phase of the seafood supply chain ................................................................................

S1.1.1 Inventory analysis of the fishing phase of the seafood supply-chain ......................................

S1.1.2 Fishing vessel, fuel quality, and fishing gear characterization. ……………………............. 8

S1.2 Inventory analysis of the primary processing phase and wholesale storage of the seafood supply-

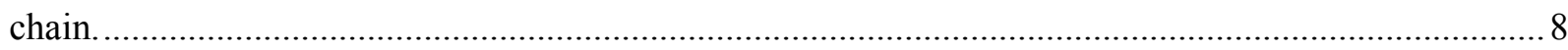

S1.3 Transportation to secondary processors phase of the seafood supply-chain. ………………............

S1.3.1 Transportation to secondary processor inputs..................................................................... 9

S1.3.2 Mass of products to secondary processors........................................................................ 11

S1.3.3 Distance of products to secondary processors. ……………................................................ 11

S1.4 Transportation of product from processor to retail distributor phase of the seafood supply-chain.13

S1.5 Retail activities phase of the seafood supply-chain. ………………........................................... 14

S2. Direct fishing vessel and container ship short-lived exhaust emission factors......................................15

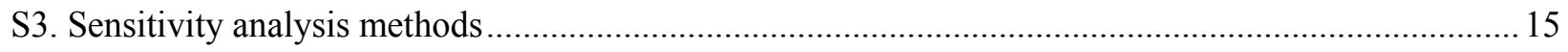

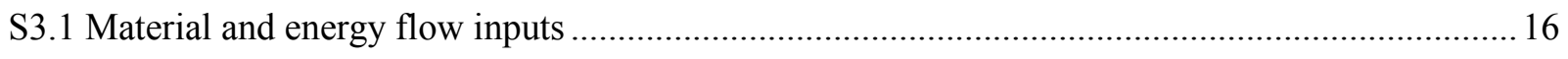

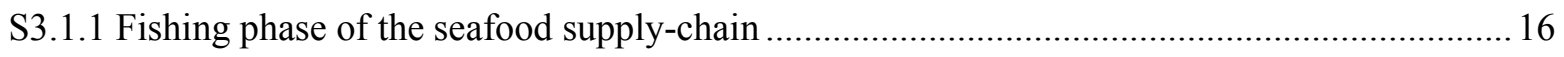

S3.1.2 Primary processing phase of the seafood supply-chain ....................................................... 16

S3.1.3 Transportation to secondary processor inputs.................................................................. 16

S3.1.4 Secondary processing ............................................................................................... 17

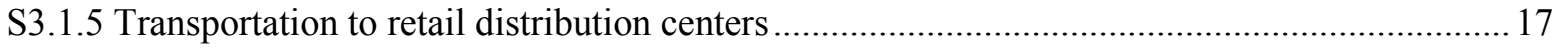

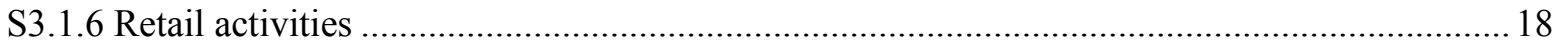

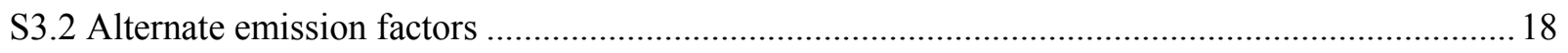

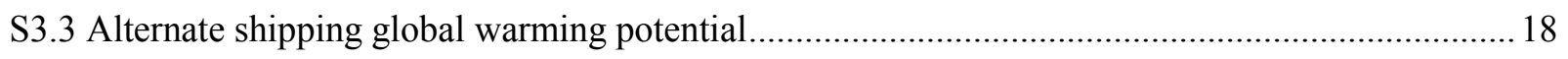

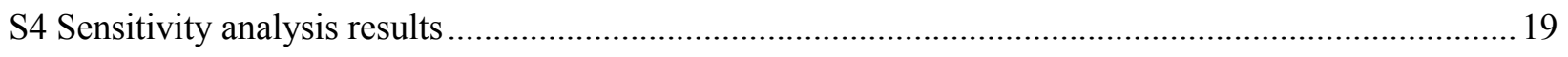

S4.1 Sensitivity analysis of the fishing phase of the seafood supply-chain........................................... 19

S4.1.1 Sensitivity analysis of parameters included in the standard deviation......................................19 
S4.1.2 Sensitivity analysis of highly uncertain parameters.

S4.2 Sensitivity analysis of the primary processing phase of the seafood supply-chain ......................20

S4.2.1 Sensitivity analysis of parameters included in the standard deviation....................................20

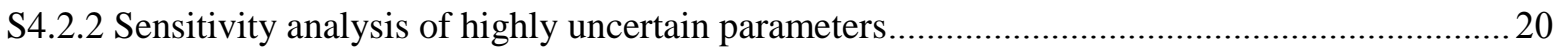

S4.3 Sensitivity analysis of the transport to secondary processor phase of the seafood supply-chain ... 21

S4.3.1 Sensitivity analysis of parameters included in the standard deviation................................. 21

S4.3.2 Sensitivity analysis of highly uncertain parameters.................................................... 22

S4.4 Sensitivity analysis of the secondary processing phase of the seafood supply-chain....................23

S4.4.1 Sensitivity analysis of parameters included in the standard deviation.................................23

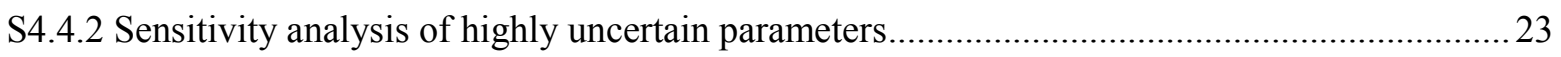

S4.5 Sensitivity analysis of the transport to retail phase of the seafood supply-chain ........................25

S4.5.1 Sensitivity analysis of parameters included in the standard deviation..................................25

S4.5.2 Sensitivity analysis of highly uncertain parameters........................................................ 25

S4.6 Sensitivity analysis of the retail phase of the seafood supply-chain..........................................22

S4.6.1 Sensitivity analysis of parameters included in the standard deviation.................................27

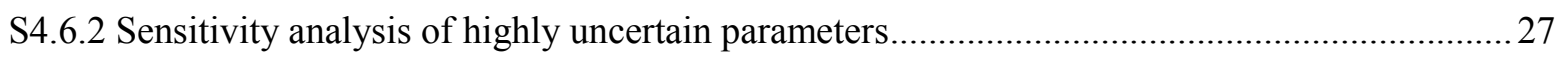

S4.7 Sensitivity analysis of the sum total of the seafood supply-chain ............................................29

S4.7.1 Sensitivity analysis of parameters included in the standard deviation..................................29

S4.7.2 Sensitivity analysis of highly uncertain parameters...................................................29

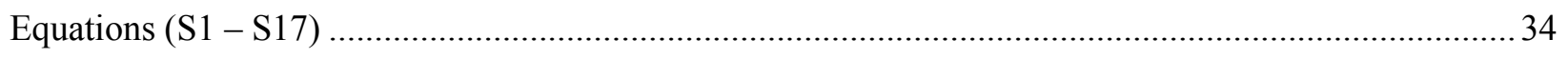

$\mathrm{S} 1$. The mass of metals used in the manufacture and maintenance of the fishing vessels........................ 34

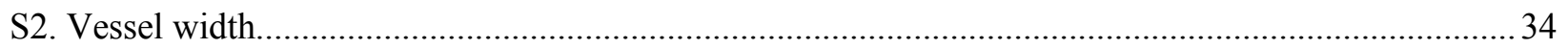

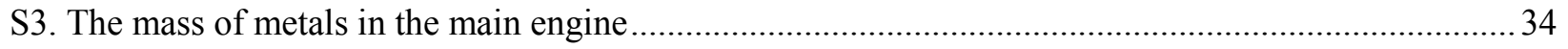

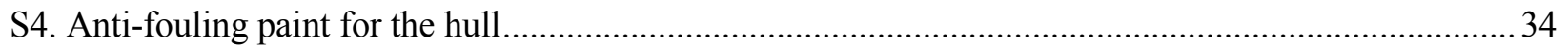

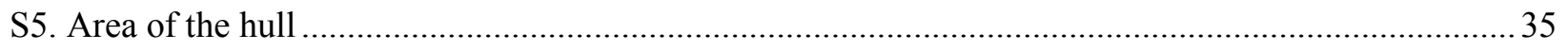

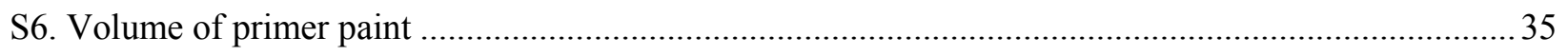

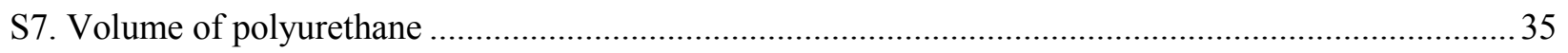




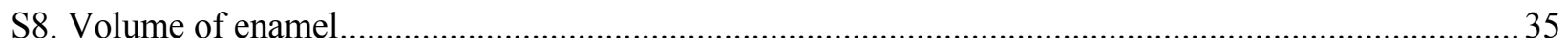

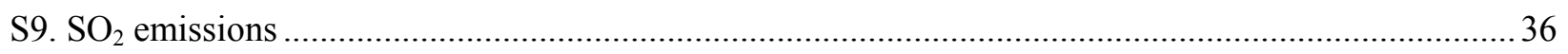

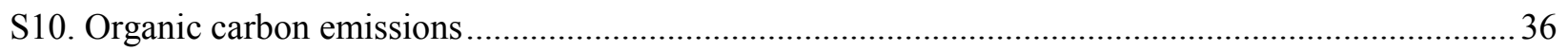

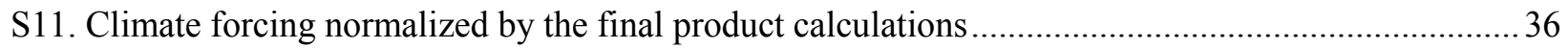

S12. Climate forcing normalized by the final product for fishing activities .......................................... 36

S13. Climate forcing normalized by the final product for primary processing....................................... 37

S14. Climate forcing normalized by the final product for transportation to secondary processors ............. 38

S15. Climate forcing normalized by the final product for secondary processing .................................... 38

S16. Climate forcing normalized by the final product for transportation to retailer.................................. 38

S17. Climate forcing normalized by the final product for the retail market ........................................... 39

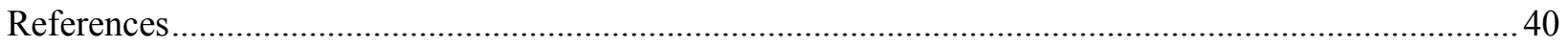

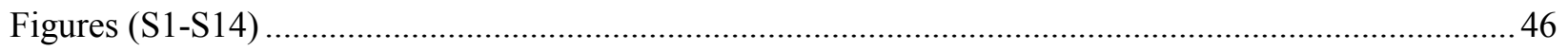

Figure S1. Linear relationship between engine weight and rated power. ............................................... 46

Figure S2. Energy mix for electricity of each market considered in this study. .................................... 47

Figure S3. Sensitivity analysis of standard deviation parameters of the fishing phase of the seafood

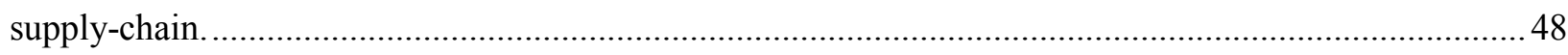

Figure S4. Sensitivity analysis of highly uncertain parameters for the fishing phase of the seafood supplychain.

Figure S5. Sensitivity analysis of standard deviation parameters for the primary processing phase of the seafood supply-chain.

Figure S6. Sensitivity analysis of highly uncertain parameters of the primary processing phase of the seafood supply-chain.

Figure S7. Sensitivity analysis of standard deviation parameters of transportation to secondary processors.

Figure S8. Sensitivity analysis of highly uncertain parameters of transportation to secondary processors.

Figure S9. Sensitivity analysis of standard deviation and highly uncertain parameters of secondary processing. 
Figure S10. Sensitivity analysis of standard deviation parameters of transportation to retailer phase of the seafood supply-chain.

Figure S11. Sensitivity analysis of highly uncertain parameters of transportation to retailer phase of the seafood supply-chain. .58

Figure S12. Sensitivity analysis of standard deviation and highly uncertain parameters of the retail phase.

Figure S13. Sensitivity analysis of standard deviation of all phases of the seafood supply-chain.

Figure S14. Sensitivity analysis of highly uncertain variables of all phases of the seafood supply-chain. 64

Tables (S1-S37) . .65

Table S1. Fuel consumption of the American Fisheries Act catcher-processor pelagic trawl fleet 65

Table S2. Mass and materials used in the manufacture of fishing gears obtained from the literature........ 66

Table S3. Vessel characteristics of the American Fisheries Act fleet .....................................................6 67

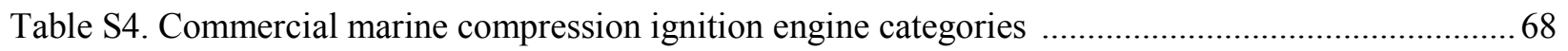

Table S5. Annual catch at the vessel level for the EBS catcher-processor AFA fleet ...........................69

Table S6. Bering Sea \& Aleutian Islands at-sea and shoreside production of pollock product .................70

Table S7. Annual disposition of frozen Alaska pollock fillet blocks to top three markets ....................... 71

Table S8. Annual disposition of frozen Alaska pollock surimi blocks to top three markets .....................72

Table S9. Container ship distances to ports by route as estimated by distance calculators ...................... 73

Table S10. Estimated truck driving distances and driving times from arrival Ports to processors .............74

Table S11. Estimated truck driving distances and driving times from processors to retail distributors ..... 75

Table S12. Transportation inputs of frozen Alaska pollock fillet blocks for three different port destinations .76

Table S13. Transportation inputs of frozen Alaska surimi fillet blocks for three different port destinations

Table S14. Transportation inputs for frozen Alaskan pollock battered-and-breaded fillets for three

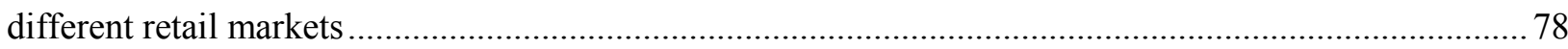

Table S15. Transportation inputs for crab-flavored sticks for three different retail markets..................... 79

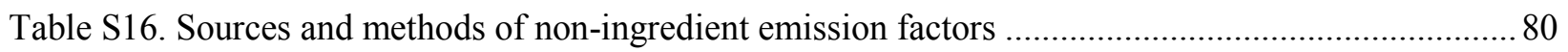




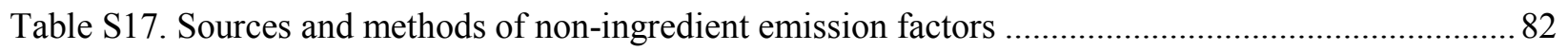

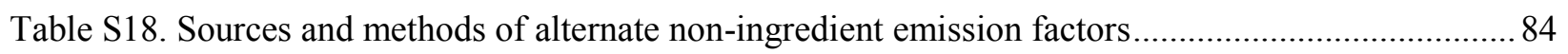

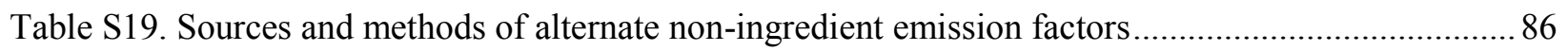

Table S20. Fishing vessel emission factors for long-lived climate forcing pollutants ............................ 88

Table S21. Emission factors of black carbon and organic carbon pollutants as a function of engine speed

Table S22. Container ship emission factors by trip segment and fuel type ...........................................90

Table S23. Heavy-duty truck emission factors ................................................................................. 91

Table S24. Indirect emission factors of non-ingredient materials and fuels ......................................... 92

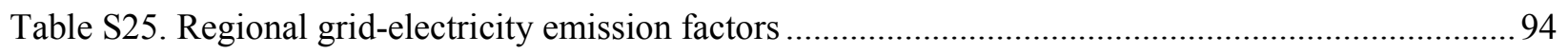

Table S26. Indirect emission factors of ingredient materials .................................................................. 95

Table S27: Mean global metric global warming potentials.............................................................. 96

Table S28. Shipping sector global warming potentials of short-lived pollutants .................................... 97

Table S29. Sensitivity analysis parameters of the seafood supply-chain: values included in the standard

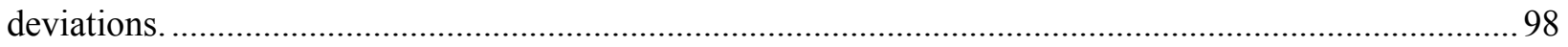

Table S30. Sensitivity analysis of highly uncertain parameters of the fishing phase of the seafood supply-

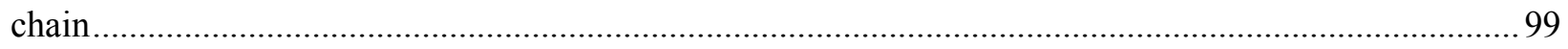

Table S31. Sensitivity analysis of highly uncertain parameters of the primary processing phase of the seafood supply-chain

Table S32. Sensitivity analysis parameters of the transportation to secondary processor phase of the seafood supply-chain: highly uncertain values not included in the standard deviations......................... 101

Table S33. Sensitivity analysis of highly uncertain parameters of transportation to retailer.................... 102

Table S34. Sensitivity analysis of highly uncertain parameters of the retail phase of the seafood supplychain. 103

Table S35. Alternate emission factors for the non-ingredient materials used in the sensitivity analysis 104

Table S36. Alternate emission factors of the ingredient materials used in the sensitivity analysis ......... 105

Table S37. Alternate container-ship exhaust emissions used in the sensitivity analysis ........................ 106 


\section{Supplementary text (S1-S4)}

\section{S1. Inventory of material and energy flows of the seafood supply-chain}

\section{S1.1 Fishing phase of the seafood supply chain}

\section{S1.1.1 Inventory analysis of the fishing phase of the seafood supply-chain}

We based our estimate of fuel consumption on a vessel fuel survey conducted by the National Marine

Fisheries Service (NMFS) (Table S1) (Fissel et al., 2016).

We estimated the annual lubricating oil consumption of the fleet as the product of the annual lubricating oil consumption of the factory trawler Hermes , reported to be $14,000 \mathrm{~kg}$ (Ziegler et al., 2015), and the number of active vessels in the fleet. The factory trawler Hermes has similar characteristics of the vessels in the eastern Bering Sea (EBS) catcher-processor pollock fleet (1,572 GT, 55m length overall, 4-stroke 4,000 kW medium-speed-diesel engine) (IHS Markit Global, 2017).

Refrigerant leakage rates on ships varies between 15-45\% (Smith et al., 2014). We estimated the annual refrigerant for air conditioning supplied to each fleet by applying the initial charge of air conditioning, 150 $\mathrm{kg}$ of R-404a per fishing vessel, and an a leakage rate of 30\% per year (Smith et al., 2014) to the number of active vessels in the fleet.

We estimated the mass of metal components of the ship and the total mass of the ship using Equations S1 and S2, respectively. Following (Fréon et al., 2014), approximately $80 \%$ of the light ship weight (LSW) was assumed to correspond to the mass of the steel hull (including the frame, steel sheets, deck, etc.). The remaining $20 \%$ of the LSW value corresponds to the mass of other structural elements and, propulsion. The composition of the other structural elements and propulsion was assumed to be: $43 \%$ as steel, $33 \%$ as copper wire (mostly coil) and $24 \%$ as aluminum. A maintenance factor was added based on (Tyedmers, 2000 ), which assumed $25 \%$ of the original material and energy inputs would be used over the lifetime of that vessel for maintenance. Although the lifetime of trawlers can vary between 30-50 years (Ziegler et al., 2015), in this study a lifetime of 30 years was assumed which is consistent with other seafood lifecycle assessments (Fulton, 2010; Parker and Tyedmers, 2012; Ziegler et al., 2015).

We estimated the mass of the main engine of each vessel was using a linear relationship between the rated engine power and engine weight of the Wärtsilä 32 engines (Wärtsilä Corporation, 2016) (Figure S1 and Equation S2). The metal composition of the main engine (65\% cast iron, $34 \%$ chrome steel, and $1 \%$ white metal alloys--aluminium alloy 2024, AlCuMg2) was taken from (Fréon et al., 2014). The main engine 
lifetime has been estimated to be 15 years and the main engine is replaced once over the lifetime of the vessel (Fréon et al., 2014).

We estimated the composition of and the lifetime of (five years) the pelagic trawl gear using the data reported by Fulton (2010) (Table S2)

\section{S1.1.2 Fishing vessel, fuel quality, and fishing gear characterization.}

We characterized the EBS catcher-processor fleet (targeting pollock) with respect to the number of active fishing vessels, and the fuel quality using data available from the Alaska Commercial Fisheries Entry Commission, NMFS, and the IHS Sea-web vessel databases. Our characterization of the fishing vessels also included the engine power, engine speed, and whether the vessels have refrigerated holds (Table S3). We assume the fishing vessels operate within the U.S. exclusive economic zone (EEZ) and as such, are subject to fuel-sulfur control laws. Small harbor and ocean-going vessels (category 1 and 2 engines) must use ultra-low sulfur diesel (ULSD) with a fuel sulfur level of 0.0015 (\% wt.) whereas larger ocean-going vessels are permitted to use marine gas oil (MGO) with a fuel sulfur level of 0.1 (\% wt.). Main engine power was used to estimate vessel categories (Table S4).

\section{S1.2 Inventory analysis of the primary processing phase and wholesale storage of the seafood} supply-chain.

Here, we describe our assumptions related to the primary processing phase of the seafood supply-chain which include on-board production of intermediary products and storage of the product at a wholesaler. We based our inventory of materials and energy on the literature (Schau et al., 2009; Winther et al., 2009; Fulton, 2010). Energy is consumed directly in the form of fuel used during processing of the fish onboard the fishing vessel and electricity for freezing the product. Material and indirect energy (embodied in the materials) is consumed in the manufacture of cooling agents for refrigerants, and the manufacture of packaging materials.

Our estimate of primary processing fuel consumption was based on the literature. It has been reported that factory trawlers use approximately 5-7\% of the ship fuel for processing (Eyjólfsdóttir et al., 2003; Sund, 2009; Schau et al., 2009). We used a mean value of $6 \%$ of the ship fuel for processing.

Refrigerant leakage rates on ships vary between 15-45\% (Smith et al., 2014). We estimated the annual refrigerant charge for the ship freezer holds as the product of the mass of $210 \mathrm{~kg}$ of R-134a per vessel and a leakage rate of $30 \%$ per year (Smith et al., 2014). 
Our estimate of material consumption for packaging the frozen fillet blocks was based on survey results that were reported in the literature. Fulton (2010) reported that $15.66 \mathrm{~kg}$ of cardboard carton, $10.3 \mathrm{~kg}$ of liner ( $83 \%$ cardboard and $17 \%$ wax), and $0.18 \mathrm{~kg}$ packaging film (LLDPE) are required for every metric ton of catch.

We based the initial charge of refrigerants for land-based wholesale storage on values found in the literature (Bovea et al., 2007; Blowers and Lownsbury, 2010; Cascini et al., 2016). For this study however, instead of R-404a or R-134a, we assumed ammonia $\left(\mathrm{NH}_{3}\right)$ was used as the refrigerant (Winther et al. 2009). Furthermore, we assumed $\mathrm{NH}_{3}$ has a similar initial charge requirement as other commonly used refrigerants. In the literature, the lifetime of the initial charge of freezer storage varies between 10-15 years (Bovea et al., 2007; Blowers and Lownsbury, 2010; Cascini et al., 2016). We used a value of 11.7 years for the lifetime of the initial charge of wholesale freezer storage. The initial charge of $\mathrm{NH}_{3}$ as a function of volume varies between 0.04 to $0.44 \mathrm{~kg} \mathrm{~m}^{-3}$ depending on the freezer type. We used an initial charge of $0.14 \mathrm{~kg} \mathrm{~m}^{-3}$. In the literature, the annual leakage rates of refrigerated storage vary between 4$15 \%$. We used a mean leakage rate of $9 \%$. Thus, the annual $\mathrm{NH}_{3}$ leakage rate we used as a function of volume was $\left(0.14 \mathrm{~kg} \mathrm{~m}^{-3} \times 0.09 \mathrm{y}^{-1}\right) 1.27 \times 10^{-2} \mathrm{~kg} \mathrm{NH}_{3} \mathrm{~m}^{-3} \mathrm{y}^{-1}$. We estimated the required storage volume for each product as a function of the mass of the frozen products and the mass per unit volume of the packaged products (Peter Pan Seafoods, 2016). The wholesale freezer storage time of frozen cod varies between 30 and 90 days (Winther et al., 2009). We assume a mean wholesale freezer storage time of 60 days.

We based the energy consumption of wholesale freezer storage, $2.6 \mathrm{~kJ} \mathrm{~kg}^{-1} \mathrm{~d}^{-1}$, on the literature (Winther et al., 2009).

\section{S1.3 Transportation to secondary processors phase of the seafood supply-chain.}

We assumed the transportation inputs include two modes, either heavy-duty truck or container ship. The key inputs associated with both modes of transportation include fuel to power the engines (and in the case of the container ship, the auxiliary engine), fuel for the temperature-controlled containers, and the refrigerant charge for the temperature-controlled containers. To assist with our analysis of the transportation phase, we estimated the mass and distances to secondary processing locations for each product.

\section{S1.3.1 Transportation to secondary processor inputs.}

We obtained the container ship fuel consumption and emission factors from the Greenhouse Gases, Regulated Emissions, and Energy Use in Transportation (GREET) Marine Plug-in module. The characteristics of the container ship reported in GREET's Marine Plug-in module include a 37.5 MW main engine, an 8.3 MW auxiliary engine, and a 40.4-kiloton payload. For the container ship, the engine 
load and fuel consumption factors vary based on the activity and the ship speed (Corbett, J. J. and Koehler, 2003; Endresen et al., 2007; Olmer et al., 2017). In activity-based models, the engine load factor $(\mathrm{LF})$ is related to the ship speed $\left(\mathrm{LF}=\left[\mathrm{v}_{\mathrm{actua}} / \mathrm{v}_{\max }\right]^{3}\right)$ (Moreno-Gutiérrez et al., 2012). In cruise mode container ships actual speeds vary between 18-21 knots (Rodrigue et al., 2013) which (if the maximum speed is 22 knots) corresponds to a LF between 51-93\%. We assumed a mean actual-vessel-speed of 19.5 knots, a corresponding LF of 0.65 , and a fuel consumption rate of $3.51 \times 10^{-3} \mathrm{~kg}$ fuel t-km ${ }^{-1}$. In reducedspeed-zone modes, container ships actual speeds vary between 9-12 knots (Yau et al., 2012). We assumed a mean actual-vessel speed of 10.5 knots in reduced-speed-zone mode, a corresponding LF of 0.10 , and a fuel consumption rate of $1.41 \times 10^{-3} \mathrm{~kg}_{\text {fuel }} \mathrm{t}-\mathrm{km}^{-1}$. At berth (or in hotel mode), LFs vary between $0.17-$ 0.23 (Moreno-Gutiérrez et al., 2012). We assumed a mean LF of 0.20 and a fuel consumption rate of 376 $\mathrm{kg} \mathrm{h}^{-1}$. The amount of time container ships spend in hotel mode varies between 7-27 hours depending on the location (United Nations Conference on Trade and Development, 2018). We assumed the global average of 42 hours ( 21 hours at the departure port and 21 hours at the arrival port).

To account for the different fuel qualities used by container ships on voyages, we used a distance calculator (Marine Traffic, 2018) to estimate the distance traveled in emission control areas (ECAs). Within ECAs, the ships use MGO with a fuel sulfur level of $0.1 \%$ (percent wt.). Outside ECAs, ships are allowed to use heavy fuel oil (HFO) with a fuel sulfur level as high as 3.5 (\% wt.). For trips outside ECAs, we assume the container ship used an average fuel sulfur level of 2.4 ( $\% \mathrm{wt}$.

We estimated the amount of fuel consumed by the heavy-duty truck by using fuel consumption factors obtained from GREET's Well-to-Wheel Vehicle Editor. We selected a short-haul heavy-duty truck with a payload of approximately 24 tons that operates with ULSD. For this vehicle, the fuel consumption factor is $1.51 \times 10^{-2} \mathrm{~kg} \mathrm{ULSD} \mathrm{t}^{-1} \mathrm{~km}^{-1}$. We assumed that trips undertaken by heavy-duty truck make a return trip with half the payload.

In addition to fuel consumption for the main engine of the container ship and the motive power of the heavy-duty truck, fuel is consumed by the temperature-controlled containers. It has been reported that the freezer duty cycle of temperature-controlled containers while transported by container ships is $19 \%$ of the fuel consumption of the main and auxiliary engines and can vary $\pm 60 \%$ (Fitzgerald et al., 2011).We assumed a freezer duty cycle of $19 \%$ of the total ship fuel for the temperature-controlled containers. It has been reported that when the temperature-controlled containers are transported by truck, however, the fuel consumption of the freezer duty-cycle varies between 1.5-4 1 fuel hour ${ }^{-1}$, depending on the dimensions of the temperature-controlled containers, temperature settings, and the ambient temperature. We assumed the 
fuel consumption rate of a $79 \mathrm{~m}^{3}$ temperature-controlled container/semi-trailer set at $0^{\circ} \mathrm{C}, 31$ fuel hour ${ }^{-1}$ (Tassou et al., 2009).

We also estimated refrigerant losses for the temperature-controlled containers and air conditioning in the cabin. Refrigerant leakage rates on ships vary between 15-45\% (Smith et al., 2014). The annual refrigerant charge of the air conditioning in the cabin of the container ship is $150 \mathrm{~kg} \mathrm{R}-404 \mathrm{a}$ with a loss rate of $30 \%$ (Smith et al., 2014). Refrigerant leakage rates of temperature-controlled containers vary between 5-30\% (Tassou et al., 2009). We assumed an annual refrigerant charge of the temperaturecontrolled container was $6 \mathrm{~kg}$ R-404a per unit with a loss rate of 15\%, (Tassou et al., 2009).

\section{S1.3.2 Mass of products to secondary processors.}

The mass of the products includes the pallets and containers. In addition, we estimated the disposition of the product to each market location (Tables S7 and S8).

We estimated the shipping mass as the product of the maximum gross mass of the twenty-foot equivalent (TEU) containers and the number of TEU containers. The maximum payload of a TEU container is 22 metric tons and the mass of each TEU is approximately 2 metric tons (Freight Filter, 2013), giving the TEU a gross mass of 24 metric tons. We estimated the total number of TEUs as the quotient of the total mass of the product (including packaging and pallets) and the TEU payload. We estimated the gross mass of the pallets as the product of the number of pallets and the mass of each pallet. The mass of each pallet is approximately $18 \mathrm{~kg}$ (Greenway Products and Services, LLC, 2018). We estimated the total number of pallets as the quotient of the mass of the product (with packaging) and the payload of the pallet. The maximum payload of a pallet is $1,180 \mathrm{~kg}$ (Graham, 1984).

\section{S1.3.3 Distance of products to secondary processors.}

In the case of exported products, we considered a variety of route calculators to estimate the distances traveled by the container ships (Table S9) and heavy-duty trucks (Table S10). The distance traveled by the container ship may vary depending on the route selected by the captain. Weather, wind speed, wave height, ice conditions, port and passage accommodation (which depends on the size of the vessel), delays at ports and/or port congestion are all factors that may influence the captain's route selection (Corbett et al., 2012; Clark et al., 2014). In the case of heavy-duty truck shipments, distances traveled may vary as a result of route diversion generated by unplanned road congestion and/or restrictions and other supplychain uncertainties (Sanchez-Rodrigues et al., 2010).

For the German market, we assume packaged frozen fish fillet blocks are transported a distance of 19,150 km by container ship from the Port of Dutch Harbor to the Port of Hamburg (via route 2) (Table S9). Approximately 17,811 km of the trip occurs outside ECAs. For 18,917 and $233 \mathrm{~km}$ of the trip, the 
container ship operates in cruise and reduced speed zone modes, respectively. Furthermore, the duration of the container ship trip is 22 days and 2.8 hours, 12 hours, and 42 hours in cruise, reduced speed zone, and hotel modes, respectively. From the Port of Hamburg, the temperature-controlled containers are shipped by the heavy-duty truck a distance of $166.8 \mathrm{~km}$ (average distance between the port and two major seafood processors in Bremerhaven and one major processor in Riepe), one-way (Table S10). The total duration of the trip one-way is 1.88 hours.

For the Netherlands market, we assume packaged frozen fish fillet blocks are transported a distance of $18,681 \mathrm{~km}$ by container ship from the Port of Dutch Harbor to the Port of Rotterdam (via route 2) (Table S9). Approximately 9,454 km of the trip occurs outside ECAs. For 11,675 and 233 kilometers of the trip the container ship operates in cruise and reduced speed zone modes, respectively. Furthermore, the duration of the container ship trip is 21 days and 12 hours, 12 hours, and 42 hours in cruise, reduced speed zone, and hotel modes, respectively. From the Port of Rotterdam, the temperature-controlled containers are shipped by the heavy-duty truck a distance of $113.6 \mathrm{~km}$ (average distance to Urk), one-way (Table S10). The total duration of the trip one-way is 1.2 hours.

For the Japanese market, we assumed packaged frozen surimi blocks are transported a distance of 4,864 km by container ship from the Port of Dutch Harbor to the Port of Nagoya (via route 1) (Table S9). Based on the route mapped by the distance calculator (Marine Traffic, 2018), we assume the entire trip occurs outside ECAs. For 4,764 and 233 kilometers of the trip the container ship operates in cruise and reduced speed zone modes, respectively. Furthermore, the duration of the container ship trip is 5 days and 12 hours, 12 hours, and 42 hours in cruise, reduced speed zone, and hotel modes, respectively. From the Port of Nagoya, we assume the temperature-controlled containers are shipped by the heavy-duty truck a distance of $12.5 \mathrm{~km}$ (average distance to Nagoya City), one-way (Table S10). We assumed the total duration of the trip one-way was 0.39 hours.

For the South Korean market, we assume packaged frozen surimi blocks are transported a mean distance of $5.502 \mathrm{~km}$ from the Port of Dutch Harbor to the Port of Busan by container ship (via route 1) (Table S9). Based on the route mapped by the distance calculator (Marine Traffic, 2018), we assume the entire trip occurs outside ECAs. For 5,269 and 233 kilometers of the trip the container ship operates in cruise and reduced speed zone modes, respectively. Furthermore, the duration of the container ship trip is 6 days and 2 hours, 12 hours, and 42 hours in cruise, reduced speed zone, and hotel modes, respectively. From the Port of Busan, the temperature-controlled containers are shipped by the heavy-duty truck a distance of $2.5 \mathrm{~km}$, one-way. We assumed the total duration of the trip one-way was 0.08 hours. 
For the domestic market, we assumed that packaged frozen fish fillet blocks and packaged frozen surimi blocks were processed in the same location. Furthermore, we assumed each product was transported a distance of $16.9 \mathrm{~km}$ by heavy-duty truck from the point of landing to an on-shore processor. We estimated the distance using commodity flow survey data (US Census Bureau, 2013). We applied several filters: export data was excluded, refrigerated truck shipments originating from Seattle and destined for various regions throughout the U.S. was selected, "meat, poultry, fish, seafood, and their preparations" commodities in the standard classifications of transported goods was selected, and the following North American industry classification systems: "grocery and related product merchant wholesalers" and "food manufacturing" were selected. We assumed an average traveling speed of $72.4 \mathrm{~km} \mathrm{~h}^{-1}$, and that the total duration of the trip was 0.23 hours.

\section{S1.4 Transportation of product from processor to retail distributor phase of the seafood supply-} chain.

We assumed the exported products (packaged frozen battered-and-breaded fillets to Germany and Netherlands, and packaged frozen crab-flavored sticks to Japan and South Korea) were transported by heavy-duty truck to retail distribution centers. In the case of products for the domestic market, however, we assumed the products would be first be transported from Dutch Harbor by container ship to the Port of Seattle, and then transported by heavy-duty truck to retail distribution centers.

We assumed the same characteristics and operating conditions of the heavy-duty truck and container ship outlined in Text S1.3.1. We also made the same assumptions to estimate the gross shipping mass of the finished products (packaged frozen battered-and-breaded fillets and packaged frozen crab-flavored sticks) as in Text S1.3.2.

Here, we describe our assumptions related to the distances traveled by heavy-duty trucks of the exported products (Table S11). Due to the limited availability of heavy-duty truck transport statistics of foreign markets (e.g. distances in commodity flow surveys) (International Energy Agency, 2017), we relied on literature estimates from food life-cycle assessment studies for distances traveled in some instances. In our review of the literature, we found that distances traveled by heavy-duty truck in European markets vary between 80-2,000 km (Pretty et al., 2005; Van Passel, 2013; Ziegler et al., 2013). The distance traveled may depend on the commodity, whether the goods are transported to (and consumed by) local markets, or whether the goods travel far from where the commodity is produced (and consumed) (Van Passel, 2013). We assumed that packaged frozen battered-and-breaded fillets exported to European retail markets (Germany and Netherlands) would be transported 1,500 km based on the average distance all food travels within continental Europe (Pretty et al., 2005). In the case of exported products to South Korea, we estimated the distance along the Seoul-Busan corridor, $391 \mathrm{~km}$, where import and export 
commodities are mainly shipped in Korea (Park and Hahn, 2015) using a distance calculator (www.distance.to/Busan/Seoul). In the case of exported products to Japan, we assumed the average of truck distances reported in the transport of fresh tomatoes from producers to consumers in Tokyo, 1,016 km (Roy et al., 2008).

In the case of products destined for the U.S. retail markets, we assumed the products were transported a distance of 3,180 km by container ship from the Port of Dutch Harbor to the Port of Seattle as estimated by the distance calculator (Marine Traffic, 2018) (Table S9). Furthermore, according to the distance calculator, 1,217 km of the trip occurs within ECAs. The container ship operates in cruise and reduced speed zone modes, or 2,947 and 233 kilometers of the trip, respectively. Furthermore, we assumed the duration of the container ship trip was 3 days and 9.6 hours, 12, and 42 hours in cruise, reduced speed zone, and hotel modes, respectively. From the Port of Seattle, the heavy-duty truck carrying the temperature-controlled containers travel a distance of $2,341 \mathrm{~km}$, one-way. This distance was estimated using commodity flow survey data (US Census Bureau, 2013). Several filters were applied: export data was excluded, refrigerated truck shipments originating from Seattle and destined for various regions throughout the U.S. was selected, "meat, poultry, fish, seafood, and their preparations" commodities in the standard classifications of transported goods was selected, and the following North American industry classification systems: "grocery and related product merchant wholesalers" and "food manufacturing" were selected.

\section{S1.5 Retail activities phase of the seafood supply-chain.}

Here, we describe key assumptions related to material and energy consumption while the product is being stored at a retail distribution center, while the product is being stored at the retail store prior to display, and during the time it is on display at the retail store.

We applied the annual initial charge for the freezer (retail distribution storage, retail storage, and retail display freezer) of $0.012 \mathrm{~kg} \mathrm{~m}^{-3} \mathrm{y}^{-1}$ to the estimated volumes of each product (described in Text S1.2) (Bovea et al., 2007; Blowers and Lownsbury, 2010; Cascini et al., 2016).

In the case of frozen battered-and-breaded fillets, we assumed the energy consumption of freezer storage (wholesale, retail, and display case) was $2.6 \mathrm{~kJ} \mathrm{~kg}^{-1} \mathrm{~d}^{-1}$ (Winther et al., 2009). In the case of crab-flavored sticks, we assumed that after the product arrives at the retail location, it is allowed to thaw and stored in a refrigerated case which requires $10 \mathrm{kWh} \mathrm{m}^{-2}$ (Hoang et al., 2016).

It has been reported that the electricity for ancillary operations (lights, air conditioning, etc.) of retail stores varies between 850 to $1500 \mathrm{kWh} \mathrm{m}^{-2} \mathrm{y}^{-1}$ (Tassou et al., 2011). Furthermore, it was also reported that between $30-60 \%$ of the electricity consumption is allocated to refrigeration systems. We assumed a mean 
value of $1,175 \mathrm{kWh} \mathrm{m}^{-2} \mathrm{y}^{-1}$ for electricity for ancillary operations allocated a mean value of $55 \%$ lighting and other operations that do not include refrigeration (Tassou et al., 2011).

We assumed that the storage time and time spent in retail display cases would be the same for all products: storage time of 7 days at a wholesale distribution center, a storage time of 10 days at the retail store prior to retail display, and 10 days in the retail display freezer (Winther et al., 2009).

\section{S2. Direct fishing vessel and container ship short-lived exhaust emission factors.}

We assumed the sulfur dioxide $\left(\mathrm{SO}_{2}\right)$ emissions depend on the fuel quality used by the fleet. For the Alaskan pollock catcher-processor pelagic trawl fleet, approximately $23 \%$ of the fleet is classified as a Category 2 engine operating with ULSD (fuel sulfur $0.0015 \%$ wt.) and the remainder is classified as Category 3 engine operating with MGO (fuel sulfur $0.1 \%$ wt.). The emissions from the container ship depend on a number of factors including ship activity mode and fuel quality. The emission factors differ depending on whether the ship activity mode is reduced-speed zone, cruise, or hoteling at the harbor. Furthermore, the emissions are dependent on the fuel quality of the ship during periods that the ships travel in and out of ECAs. When the ship is traveling in an ECA, the ship is required to use MGO with a fuel sulfur level of 0.1 (\% wt.). Outside of ECAs the ship is allowed to burn poor quality fuel, HFO with an average sulfur level of 2.4 (\% wt.).

We assumed the fishing vessel emissions of black carbon (BC) and organic carbon (OC) depend on the fleet engine speed. For the Alaskan pollock catcher-processor pelagic trawl fleet, we searched the Seaweb database for International Maritime Organization numbers and vessel names to estimate vessel engine speed. The search returned only one result, with a vessel speed of $900 \mathrm{rpm}$. Because the engine speeds were not available for all of the vessels in the fleet, we assumed the fleet is comprised of mediumspeed diesel (MSD) engines, which is consistent with what other studies have found for fishing fleets (Lack et al., 2008). The mean and 95\% confidence intervals $0.41( \pm 0.27), 0.85( \pm 0.14), 0.48( \pm 0.16) \mathrm{g}$ $\mathrm{BC} \mathrm{kg} \mathrm{fuel}^{-1}$ for slow-speed diesel (SSD), medium-speed diesel (MSD), and high-speed diesel (HSD) engines, respectively (Lack et al., 2008; Petzold et al., 2011; Buffaloe et al., 2014; Cappa et al., 2014). For the container ship BC and OC emissions factors, we used the values from the GREET Marine Plug-in module.

\section{S3. Sensitivity analysis methods}

We conducted a sensitivity analysis to understand which variables contribute most to the variation in the standard deviations and to evaluate the impact of highly uncertain variables. We used a one-parameter-ata-time approach. In the instances when the parameter we adjusted appeared in both the numerator and the 
denominator of our net climate forcing calculations (Equations S12-S17), we held the value in the denominator constant.

\section{S3.1 Material and energy flow inputs}

\section{S3.1.1 Fishing phase of the seafood supply-chain}

In the case of variables included in the standard deviations, we added and subtracted twice the standard deviations to the mean values. Here, the variables include the mass of the total catch by the American Fisheries Act (AFA) fleet, the total mass of at-sea pollock products, the mass of the at-sea pollock catch, AFA fleet fuel consumption (main engine and fuel allocated to primary processing), AFA fleet characteristics (number of vessels and light ship weights), mass of the main engine, emission factors (BC and OC), and shipping SLCF GWPs which include nitrogen oxides (NOx), sulfur oxides (SOx), BC, and OC (Table S29). We also considered highly uncertain variables (not included in the standard deviations) which include ship refrigerant leakage (for air conditioning), and lifetimes (vessels, engine, paint, and fishing gear) (Table S30). Furthermore, we considered scenarios using alternate non-electricity emission factors (see Text S3.2) and global GWPs instead of shipping GWPs (see Text S3.3).

\section{S3.1.2 Primary processing phase of the seafood supply-chain}

In the case of variables included in the standard deviations, we added twice the standard deviations to the mean values. Here, the variables include the mass of the total catch by the AFA fleet, the total mass of atsea pollock products, the mass of the at-sea pollock catch, AFA fleet fuel consumption (main engine and fuel allocated to primary processing), AFA fleet characteristics (number of vessels and light ship weights), mass of the main engine, emission factors (BC and OC), and shipping SLCF GWPs (NOx, SOx, $\mathrm{BC}$, and $\mathrm{OC}$ ) (Table S29).

The highly uncertain variables (not included in the standard deviations) we considered are presented in Table S31. Furthermore, we considered scenarios using global GWPs instead of shipping GWPs (see Text S3.3).

\section{S3.1.3 Transportation to secondary processor inputs}

In the case of variables included in the standard deviations, we added and subtracted twice the standard deviations to the mean values. Here, the variables include the mass of the pollock catch by the AFA fleet, fraction of at-sea fillets of total pollock fillets (processed by catcher-processors and processed on-shore), fraction of at-sea surimi of total pollock surimi (processed by catcher-processors and processed on-shore), mass of surimi to top markets, mass of fillets to top markets, and shipping GWPs of SLCFs (NOx, SOx, $\mathrm{BC}$, and OC) (Table S29). 
In the case of highly uncertain variables (not included in the standard deviations), we included ship distances, ship cruising speed, ship reduced-speed-zone speed, ship hotel LF, ship hotel hours, ship HFO sulfur levels, the fuel consumption of the ship for the temperature-controlled containers, the fuel consumption of the heavy-duty truck for the temperature-controlled containers, refrigerant leaks of the temperature-controlled containers, and the distances traveled (from arrival port to the secondary processors) by the heavy-duty trucks (Table S32).

We calculated alternate ship emission factors to complement the alternate sensitivity parameters related to shipping (see Text S3.2). In addition, we considered global GWPs instead of shipping GWPs (see Text S3.3).

\section{S3.1.4 Secondary processing}

In the case of variables included in the standard deviations, we added and subtracted twice the standard deviations to the mean values. Here, the variables include the mass of the pollock catch by the AFA fleet, the mass of at-sea pollock catch, and the mass of at-sea pollock intermediary products (fillets or surimi) (Table S29).

The parameters we considered highly uncertain variables (not included in the standard deviations) include the storage time of the products before they are distributed to retail distribution centers, alternate emission factors for ingredients and non-ingredient materials, and alternatives to regional grid-electricity. In the case of storage time of the products, we adjusted the mean storage time of 30 days (Vázquez-Rowe et al., 2013) by \pm 15 days as an arbitrary adjustment due to a lack of detailed information about storage of product at processors for pollock supply-chains . By increasing the storage time by 15 days, we adjusted the electricity consumption for ancillary operations by $\pm 2.01 \times 10^{-1} \mathrm{kWh} \mathrm{kg} \mathrm{product}^{-1}$ (from the mean value of $4.02 \times 10^{-1} \mathrm{kWh} \mathrm{kg}$ product $^{-1}$ ). We also considered scenarios using alternate emission factors for non-ingredient materials (see Text S3.2). Furthermore, we considered scenarios using global GWPs instead of shipping GWPs (see Text S3.3).

\section{S3.1.5 Transportation to retail distribution centers}

In the case of variables included in the standard deviations, we added and subtracted twice the standard deviations to the mean values. Here, the variables include the mass of the pollock catch by the AFA fleet, fraction of at-sea fillets of total pollock fillets (processed by catcher-processors and processed on-shore), fraction of at-sea surimi of total pollock surimi (processed by catcher-processors and processed on-shore), mass of surimi to top markets, mass of fillets to top markets, and shipping GWPs of SLCFs (NOx, SOx, BC, and OC) (Table S29). 
In the case of highly uncertain variables (not included in the standard deviations), we included ship cruising speed, ship reduced-speed-zone speed, ship hotel LF, ship hotel hours, ship HFO sulfur levels, the fuel consumption of the ship for the temperature-controlled containers, the fuel consumption of the heavy-duty truck for the temperature-controlled containers, refrigerant leaks of the temperature-controlled containers, and the distances traveled (from arrival port to the secondary processors) by the heavy-duty trucks (Table S33).

\section{S3.1.6 Retail activities}

In the case of variables included in the standard deviations, we added or subtracted twice the standard deviations to the mean values. We included the mass of the pollock catch by the AFA fleet, the mass of at-sea pollock products, and the mass of intermediary products (at-sea fillets or at-sea (Table S29).

The parameters we considered highly uncertain variables (not included in the standard deviations) include the storage time of the products before they are distributed (at the retail distribution center, at the retail store, and in the display case), $\mathrm{NH}_{3}$ refrigerant leakage, the electricity consumption of ancillary operations, and the fraction of electricity for ancillary operations allocated to refrigeration (Table S34).

\section{S3.2 Alternate emission factors}

For certain phases of the seafood supply-chain, we applied alternate emission factors (alternative nonexhaust emissions, alternatives to regional grid-electricity, and alternative shipping exhaust emissions).

We applied alternatives to non-exhaust emissions to the fishing, primary processing, and secondary processing phases of the seafood supply-chain., We obtained these alternative emission factors from Simapro using the Ecoinvent database (unless otherwise indicated) and the GWP 100a method (noningredient emission factors in Table S35 and ingredient emission factors in Table S36). Because Simapro does not provide $\mathrm{BC}$ and $\mathrm{OC}$ emissions to air, we computed these values by estimating the fractional contribution from the particulate matter that is 2.5 micrometers and smaller $\left(\mathrm{PM}_{2.5}\right)$ from each primary fossil energy source of emissions (coal, natural gas, and crude oil) as described in (Cai and Wang, 2014).

We applied alternative shipping exhaust emissions to the transport to secondary processor and transport to retailer phases of the seafood supply-chain. We calculated alternate shipping exhaust emission factors using GREET's Marine Plug-in module (Table S37).

\section{S3.3 Alternate shipping global warming potential}

For certain phases of the seafood supply-chain (fishing, primary processing, transport to secondary processor, and transport to retail distribution center), alternate global warming potentials (GWPs) were applied to SLCF pollutants resulting from ship exhaust. In this case, instead of GWPs specific to the shipping industry, we applied global mean metric GWPs (Table S27). 


\section{S4 Sensitivity analysis results}

Although we considered over 40 parameters over the entire seafood supply-chain in our sensitivity analysis, here we only discuss the results that have the largest impact (generally, the top three) on the baseline climate forcing values.

For the parameters that are included in the standard deviations, we ranked the values that contribute most to the variance. For the highly uncertain parameters, we discussed the sensitivity analysis (the increase or decrease) impact on the baseline values and considered the percentage increase or decrease.

\section{S4.1 Sensitivity analysis of the fishing phase of the seafood supply-chain}

\section{S4.1.1 Sensitivity analysis of parameters included in the standard deviation}

Certain shipping GWPs (NOx, BC, and OC), the main engine fuel consumption, the mass of intermediary products (fillets or surimi), and the mass of at-sea pollock contributed most to the variation in the standard deviation of the climate forcing associated with the fishing phase of pollock products (Figure S3).

\section{S4.1.2 Sensitivity analysis of highly uncertain parameters}

In the case of highly uncertain variables, the global metric GWP instead of the shipping GWP, refrigerant leakage, the vessel lifetime, and the alternative non-electricity emission factors had the largest impact on the baseline values (Figure S4).

First, we considered the global metric GWP used as an alternative to the shipping GWP. In comparison to the shipping GWP, on a 20-y time horizon, the global metric GWP has percent differences of -124\%, $17.5 \%,+4.5 \%$, and $-63.7 \%$ for $\mathrm{NOx}, \mathrm{SO}_{2}, \mathrm{BC}$, and $\mathrm{OC}$, respectively. Using the global metric GWP instead of the shipping GWP, on a 20-y time horizon, resulted in the baseline values $\left(0.34 \mathrm{~kg} \mathrm{CO}_{2} \mathrm{e} \mathrm{kg}\right.$ frozen crab-flavored stick ${ }^{-1}$ and $0.35 \mathrm{~kg} \mathrm{CO}_{2} \mathrm{e} \mathrm{kg}$ frozen battered-and-breaded fillet ${ }^{-1}$ ) increasing by 0.69 and $0.73 \mathrm{~kg} \mathrm{CO}_{2} \mathrm{e} \mathrm{kg} \mathrm{product}{ }^{-1}$ (Figures S4A and S4B). These increases resulted in values of 1.03 and $1.08 \mathrm{~kg} \mathrm{CO}_{2} \mathrm{e} \mathrm{kg} \mathrm{product}{ }^{-1}$ and a percent increase of $206 \%$ for crab-flavored sticks and battered-andbreaded fillets, respectively. In comparison to the shipping GWP, on a 100-y time horizon, the global metric GWP has percent differences of $-74 \%,-17.4 \%,+1.4 \%$, and $-64.3 \%$ for $\mathrm{NOx}, \mathrm{SO}_{2}, \mathrm{BC}$, and $\mathrm{OC}$, respectively. Using the global metric GWP instead of the shipping GWP, on a 100-y time horizon, resulted in the baseline values $\left(0.34 \mathrm{~kg} \mathrm{CO}_{2} \mathrm{e} \mathrm{kg}\right.$ frozen crab-flavored stick ${ }^{-1}$ and $0.36 \mathrm{~kg} \mathrm{CO}_{2} \mathrm{e} \mathrm{kg}$ frozen battered-and-breaded fillet ${ }^{-1}$ ) increasing by 0.25 and $0.26 \mathrm{~kg} \mathrm{CO}_{2} \mathrm{e} \mathrm{kg} \mathrm{product}^{-1}$ (Figures S4C and $\mathrm{S} 4 \mathrm{D})$. These increases resulted in values of 0.59 and $0.62 \mathrm{~kg} \mathrm{CO}_{2} \mathrm{e} \mathrm{kg}$ product $^{-1}$ and a percent increase of $73 \%$ for crab-flavored sticks and battered-and-breaded fillets, respectively. 
Second, we considered refrigerant leakage. In the case of both products on a 20 -y time horizon, adjusting the leakage rate $\pm 15 \%$ (from the baseline of $30 \%$ ) resulted in a change of $\pm 0.02 \mathrm{~kg} \mathrm{CO}_{2} \mathrm{e} \mathrm{kg} \mathrm{product}{ }^{-1}$ (Figures $\mathrm{S} 4 \mathrm{~A}$ and $\mathrm{S} 4 \mathrm{~B}$ ) and $\pm 5 \%$ difference in the baseline values.

Third, we considered vessel lifetime on a 100-y time horizon. In the case of battered-and-breaded fillets, adjusting the lifetime of the vessel $\pm 50 \%$ (baseline lifetime 30 years) resulted in a change of $\pm 8.31 \times 10^{-3}$ $\mathrm{kg} \mathrm{CO}_{2} \mathrm{e} \mathrm{kg} \mathrm{product}{ }^{-1}$ (Figure $\mathrm{S} 4 \mathrm{C}$ ) and $\pm 2 \%$ difference in the baseline value. In the case of crab-flavored sticks, adjusting the lifetime resulted in a change of $\pm 7.94 \times 10^{-3} \mathrm{~kg} \mathrm{CO}_{2} \mathrm{e} \mathrm{kg} \mathrm{product}{ }^{-1}$ (Figure S4D) and $\pm 2 \%$ difference in the baseline value.

Lastly, we considered alternative non-electricity emission factors. On a 20-y time horizon, the baseline value increased by $0.01 \mathrm{~kg} \mathrm{CO}_{2} \mathrm{e} \mathrm{kg} \mathrm{product}{ }^{-1}$ (Figure S4A and S4B) which resulted in values of 0.36 and $0.35 \mathrm{~kg} \mathrm{CO}_{2} \mathrm{e} \mathrm{kg}$ product ${ }^{-1}$ and resulted in an increase of $3 \%$ from the baseline values for battered-andbreaded fillets and crab-flavored sticks, respectively. On a 100-y time horizon, the baseline values decreased by $7.11 \times 10^{-3}$ and $6.80 \times 10^{-3} \mathrm{~kg} \mathrm{CO}_{2} \mathrm{e} \mathrm{kg} \mathrm{product}^{-1}$ (Figure S4C and S4D) which resulted in values of 0.35 and $0.33 \mathrm{~kg} \mathrm{CO}_{2} \mathrm{e} \mathrm{kg}$ product ${ }^{-1}$ and a decrease of $3 \%$ from the baseline values for batteredand-breaded fillets decreased, and crab-flavored sticks, respectively.

\section{S4.2 Sensitivity analysis of the primary processing phase of the seafood supply-chain}

\section{S4.2.1 Sensitivity analysis of parameters included in the standard deviation}

The parameters that contributed most to the climate forcing variation of the primary processing of pollock products vary depending on the time horizon (Figure S5). For both products on a 20-y time horizon, the parameters that contributed most to the climate forcing variance included at-sea intermediary products (fillets and surimi), the shipping NOx GWP, and the OC emission factor (Figures S5A and S5B). For both products on a 100-y time horizon, the parameters that contributed most to the climate forcing variance included at-sea intermediary products (fillets and surimi), the shipping NOx GWP, and the ship fuel allocated to primary processing (Figures S5C and S5D).

\section{S4.2.2 Sensitivity analysis of highly uncertain parameters}

In the case of highly uncertain variables, the global metric GWP instead of the shipping GWP, refrigerant leaks, and the number of days the products spend in storage at a wholesaler had the largest impacts on the baseline values (Figure S6).

First, we considered the global metric GWP used as an alternative to the shipping GWP. In comparison to the shipping GWP, on a 20-y time horizon, the global metric GWP has percent differences of - $124 \%$, $17.5 \%,+4.5 \%$, and $-63.7 \%$ for $\mathrm{NOx}, \mathrm{SO}_{2}, \mathrm{BC}$, and $\mathrm{OC}$, respectively. Using the global metric GWP instead of the shipping GWP, on a 20 -y time horizon, resulted in increases of baseline values $\left(5.09 \times 10^{-2}\right.$ 
$\mathrm{kg} \mathrm{CO}_{2} \mathrm{e} \mathrm{kg}$ frozen crab-flavored stick ${ }^{-1}$ and $5.32 \times 10^{-2} \mathrm{~kg} \mathrm{CO}_{2} \mathrm{e} \mathrm{kg}$ frozen battered-and-breaded fillet ${ }^{-1}$ ) by $4.12 \times 10^{-2}$ and $4.31 \times 10^{-2} \mathrm{~kg} \mathrm{CO}_{2} \mathrm{e} \mathrm{kg}$ product $^{-1}$ (Figures S6A and S6B). These increases resulted in values of $9.21 \times 10^{-2}$ and $9.63 \times 10^{-2} \mathrm{~kg} \mathrm{CO}_{2} \mathrm{e} \mathrm{kg}$ product $^{-1}$ and an increase $81 \%$ for crab-flavored sticks and battered-and-breaded fillets, respectively. In comparison to the shipping GWP, on a 100-y time horizon, the global metric GWP has percent differences of $-74 \%,-17.4 \%,+1.4 \%$, and $-64.3 \%$ for NOx, $\mathrm{SO}_{2}, \mathrm{BC}$, and $\mathrm{OC}$, respectively. Using the global metric GWP instead of the shipping GWP, on a 100-y time horizon, resulted baseline value $\left(5.44 \times 10^{-2} \mathrm{~kg} \mathrm{CO}_{2} \mathrm{e} \mathrm{kg}\right.$ frozen crab-flavored stick ${ }^{-1}$ and $5.69 \times 10^{-2}$ $\mathrm{kg} \mathrm{CO}_{2} \mathrm{e} \mathrm{kg}$ frozen battered-and-breaded fillet ${ }^{-1}$ ) increases of $1.51 \times 10^{-2}$ and $1.58 \times 10^{-2} \mathrm{~kg} \mathrm{CO}_{2} \mathrm{e} \mathrm{kg}$ product $^{-1}$ (Figures S6C and S6D). These increases resulted in values of $6.96 \times 10^{-2}$ and $7.28 \times 10^{-2} \mathrm{~kg} \mathrm{CO}_{2} \mathrm{e}$ $\mathrm{kg}_{\text {product }}{ }^{-1}$ and an increase by of $28 \%$ times for crab-flavored sticks and battered-and-breaded fillets, respectively.

Second, we considered the refrigerant leak from fishing vessels. On a $20-y$ time horizon, adjusting the leak rate $\pm 15 \%$ (from the baseline of $30 \%$ ) resulted in a change of $\pm 6.02 \times 10^{-3}$ and $5.76 \times 10^{-3} \mathrm{~kg} \mathrm{CO}_{2} \mathrm{e}$ $\mathrm{kg}$ product $^{-1}$ and a change of $\pm 11 \%$ for crab-flavored sticks and battered-and-breaded fillets, respectively (Figures S6A and S6B). On a 100-y time horizon, adjusting the leak rate $\pm 15 \%$ (from the baseline of $30 \%$ ) resulted in a change of $\pm 5.96 \times 10^{-3}$ and $5.70 \times 10^{-3} \mathrm{~kg} \mathrm{CO}_{2} \mathrm{e} \mathrm{kg} \mathrm{product}{ }^{-1}$ and a change of $\pm 10 \%$ for crab-flavored sticks and battered-and-breaded fillets, respectively (Figures S6C and S6D).

Third, we considered the number of days the product is stored. On a $20-\mathrm{y}$ time horizon, adjusting the assumed number of days the product is stored by $\pm 50 \%$ (from a baseline value of 60 days) resulted in a change of $\pm 4.20 \times 10^{-3}$ and $\pm 4.02 \times 10^{-3} \mathrm{~kg} \mathrm{CO}_{2} \mathrm{e} \mathrm{kg} \mathrm{product}{ }^{-1}$ and a change of $\pm 8 \%$ for crab-flavored sticks and battered-and-breaded fillets, respectively (Figures S6A and S6B). On a 100-y time horizon, adjusting the assumed number of days the product is stored resulted in a change of $\pm 4.85 \times 10^{-3}$ and \pm 4.64 x $10^{-3} \mathrm{~kg} \mathrm{CO}_{2} \mathrm{e} \mathrm{kg}$ product $^{-1}$ and a change of $\pm 9 \%$ for crab-flavored sticks and battered-and-breaded fillets, respectively (Figures S6C and S6D).

S4.3 Sensitivity analysis of the transport to secondary processor phase of the seafood supplychain

\section{S4.3.1 Sensitivity analysis of parameters included in the standard deviation}

For both products and time horizons, the parameters that contributed most to the climate forcing variance of the transport to secondary processor phase for both products and time horizons was the shipping SOx GWP, the mass of intermediary products to each market (surimi to Japan and South Korea, and fillets to Germany and Netherlands), and the shipping NOx GWP. Although we assumed the products for the domestic market were transported by heavy-duty truck a short distance, the results of the sensitivity analysis were negligible (Figure S7). 


\section{S4.3.2 Sensitivity analysis of highly uncertain parameters}

In the case of highly uncertain variables, the global metric GWP instead of the shipping GWP, and ship HFO sulfur levels had the largest impact on the baseline values (Figure S8).

First, we considered the global metric GWP used as an alternative to the shipping GWP. In comparison to the shipping GWP, on a 20-y time horizon, the global metric GWP has percent differences of - $124 \%$, $17.5 \%,+4.5 \%$, and $-63.7 \%$ for $\mathrm{NOx}, \mathrm{SO}_{2}, \mathrm{BC}$, and $\mathrm{OC}$, respectively. Using the global metric GWP instead of the shipping GWP, on a 20 -y time horizon, resulted in the baseline values $\left(-4.58 \times 10^{-1}\right.$ and $4.58 \times 10^{-1} \mathrm{~kg} \mathrm{CO}_{2} \mathrm{e} \mathrm{kg} \mathrm{product}{ }^{-1}$ for the German and Netherlands, respectively) increasing by $4.48 \times 10^{-1}$ and $4.39 \times 10^{-1} \mathrm{~kg} \mathrm{CO}^{\mathrm{e}} \mathrm{kg}$ product $^{-1}$ (Figures S8A and S8B). These increases resulted in values of -1.01 $\times 10^{-2}$ and $-1.96 \times 10^{-2} \mathrm{~kg} \mathrm{CO}_{2} \mathrm{e} \mathrm{kg} \mathrm{product}{ }^{-1}$, and an increase of $85 \%$ from the baseline values for the German and Netherlands markets, respectively. In the case of crab-flavored sticks on a 20-y time horizon, the baseline values $\left(-1.18 \times 10^{-1}\right.$ and $-1.31 \times 10^{-1} \mathrm{~kg}$ product $^{-1}$ for the Japanese and South Korean, and domestic markets respectively) increased by $1.10 \times 10^{-1}$ and $1.22 \times 10^{-1} \mathrm{~kg} \mathrm{CO}_{2} \mathrm{e} \mathrm{kg} \mathrm{product}{ }^{-1}$ (Figures $\mathrm{S} 8 \mathrm{D}$ and S8E). These increases resulted in values of $-8.37 \times 10^{-3}$ and $-9.23 \times 10^{-3} \mathrm{~kg} \mathrm{CO}_{2} \mathrm{e} \mathrm{kg} \mathrm{product}{ }^{-1}$, and an increase of $93 \%$ from the baseline values for the Japanese and South Korean markets, respectively. In comparison to the shipping GWP, on a 100-y time horizon, the global metric GWP has percent differences of $-74 \%,-17.4 \%,+1.4 \%$, and $-64.3 \%$ for $\mathrm{NOx}, \mathrm{SO}_{2}, \mathrm{BC}$, and $\mathrm{OC}$, respectively. Using the global metric GWP instead of the shipping GWP, on a 100-y time horizon, resulted baseline value (-7.15 x $10^{-2}$ and $-7.14 \times 10^{-2} \mathrm{~kg} \mathrm{CO}_{2} \mathrm{e} \mathrm{kg} \mathrm{product}{ }^{-1}$ for the German, and Netherlands markets, respectively) increases of $1.58 \times 10^{-1}$ and $1.52 \times 10^{-1} \mathrm{~kg} \mathrm{CO}_{2} \mathrm{e} \mathrm{kg} \mathrm{product}{ }^{-1}$ (Figures S8G and S8H). These increases resulted in values of $8.62 \times 10^{-2}$ and $8.07 \times 10^{-2} \mathrm{~kg} \mathrm{CO}_{2} \mathrm{e} \mathrm{kg} \mathrm{product}{ }^{-1}$ and an increase of $213 \%$ from the baseline values for the German and Netherlands markets, respectively. In the case of crab-flavored sticks on a 100-y time horizon, the baseline values $\left(-2.02 \times 10^{-2}\right.$ and $-2.26 \times 10^{-2} \mathrm{~kg} \mathrm{CO}_{2} \mathrm{e} \mathrm{kg} \mathrm{product}^{-1}$ for the Japanese and South Korean, respectively) increased by $3.84 \times 10^{-2}$ and $4.28 \times 10^{-2} \mathrm{~kg} \mathrm{CO}_{2} \mathrm{e} \mathrm{kg} \mathrm{product}{ }^{-1}$ (Figures S8J and S8K). These increases resulted in values of $1.82 \times 10^{-2}$ and $2.02 \times 10^{-2} \mathrm{~kg} \mathrm{CO}_{2} \mathrm{e} \mathrm{kg}$ product $^{-1}$, and an increase of $190 \%$ from the baseline values for the Japanese and South Korean markets, respectively.

Second, we considered the sulfur level in marine fuels reduction from 3.5 (\%wt.) to 0.5 (\% wt.). In the case of battered-and-breaded fillets on a 20 -y time horizon, decreasing the sulfur level in HFO by $86 \%$ resulted in increases of $3.61 \times 10^{-1}$ and $3.63 \times 10^{-1} \mathrm{~kg} \mathrm{CO}_{2} \mathrm{e} \mathrm{kg} \mathrm{product}{ }^{-1}$ (Figures S8A and S8B) which resulted in values of $-9.69 \times 10^{-2}$ and $-9.51 \times 10^{-2} \mathrm{~kg} \mathrm{CO}_{2} \mathrm{e} \mathrm{kg} \mathrm{product}{ }^{-1}$, and an increase of $79 \%$ from the baseline values for the German and Netherlands markets, respectively. In the case of crab-flavored sticks on a 20 -y time horizon, decreasing the sulfur level resulted in increases of $9.25 \times 10^{-2}$ and $1.02 \times 10^{-1} \mathrm{~kg}$ 
$\mathrm{CO}_{2} \mathrm{e} \mathrm{kg} \mathrm{product}{ }^{-1}$ (Figures S8D and S8E) which resulted in values of $-2.58 \times 10^{-2}$ and $-2.89 \times 10^{-2} \mathrm{~kg}$ $\mathrm{CO}_{2} \mathrm{e} \mathrm{kg}$ product ${ }^{-1}$, and an increase of $78 \%$ from the baseline values for the Japanese and South Korean markets, respectively. In the case of battered-and-breaded fillets on a 100-y time horizon, decreasing the sulfur level resulted in increases of $9.72 \times 10^{-2}$ and $9.77 \times 10^{-2} \mathrm{~kg} \mathrm{CO}_{2} \mathrm{e} \mathrm{kg}$ product ${ }^{-1}$ (Figures S8G and $\mathrm{S} 8 \mathrm{H}$ ) which resulted in values of $2.57 \times 10^{-2}$ and $2.63 \times 10^{-2} \mathrm{~kg} \mathrm{CO}_{2} \mathrm{e} \mathrm{kg}$ product ${ }^{-1}$, and an increase of $136 \%$ from the baseline values for the German and Netherlands markets, respectively. In the case of crabflavored sticks on a 100-y time horizon, decreasing the fuel sulfur resulted in increases of $2.49 \times 10^{-2}$ and $2.75 \times 10^{-2} \mathrm{~kg} \mathrm{CO}_{2} \mathrm{e} \mathrm{kg} \mathrm{product}{ }^{-1}$ (Figures S8J and S8K) which resulted in values of $4.69 \times 10^{-3}$ and $4.91 \mathrm{x}$ $10^{-3} \mathrm{~kg} \mathrm{CO}_{2} \mathrm{e} \mathrm{kg} \mathrm{product}{ }^{-1}$, and an increase of $122 \%$ from the baseline values for the Japanese and South Korean markets, respectively.

Third, we considered the range of sulfur levels in marine fuels, which varies \pm 1.1 (\% wt.) from the mean value of 2.4 (\%wt.). In the case of battered-and-breaded fillets on a 20 -y time horizon, adjusting the sulfur level in HFO by $\pm 46 \%$ resulted in differences of $\pm 2.34 \times 10^{-1}$ and $\pm 2.31 \times 10^{-1} \mathrm{~kg} \mathrm{CO}_{2} \mathrm{e} \mathrm{kg} \mathrm{product}{ }^{-1}$ (Figures S8A and S8B) and $\pm 51 \%$ from baseline values for the German and Netherlands markets, respectively. In the case of crab-flavored sticks on a 20 -y time horizon, adjusting the sulfur level resulted in differences of $\pm 6.16 \times 10^{-2}$ and $\pm 6.81 \times 10^{-2} \mathrm{~kg} \mathrm{CO}_{2} \mathrm{e} \mathrm{kg} \mathrm{product}{ }^{-1}$ (Figures S8D and S8E) and $\pm 52 \%$ from baseline values for the Japanese and South Korean markets, respectively. In the case of batteredand-breaded fillets on a 100-y time horizon, adjusting the sulfur level resulted in differences of $\pm 6.34 \mathrm{x}$ $10^{-2}$ and $\pm 6.02 \times 10^{-2} \mathrm{~kg} \mathrm{CO}_{2} \mathrm{e} \mathrm{kg} \mathrm{product}{ }^{-1}$ (Figures S8G and $\mathrm{S} 8 \mathrm{H}$ ) and $\pm 89 \%$ from baseline values for the German and Netherlands markets, respectively. In the case of crab-flavored sticks on a 100-y time horizon, adjusting the sulfur level resulted in differences of $\pm 1.68 \times 10^{-2}$ and $\pm 1.87 \times 10^{-2} \mathrm{~kg} \mathrm{CO}_{2} \mathrm{e} \mathrm{kg}$ product $^{-1}$ (Figures S $8 \mathrm{~J}$ and S8K) and $\pm 83 \%$ from baseline values for the Japanese and South Korean markets, respectively.

\section{S4.4 Sensitivity analysis of the secondary processing phase of the seafood supply-chain}

\section{S4.4.1 Sensitivity analysis of parameters included in the standard deviation}

For both products and time horizons, ranked in order of impact on the climate forcing variance, the leading parameters are the mass of intermediary product (fillets or surimi), the mass of AFA pollock catch, and the mass of at-sea pollock catch (Figure S9).

\section{S4.4.2 Sensitivity analysis of highly uncertain parameters}

The parameters that had the largest impact on the baseline values include the time the product spends in storage at the processing facility, and the alternative emission factors for the non-electricity emissions. 
First, we considered the number of days the product spends in storage at the processor before it is shipped to retailers. In the case of battered-and-breaded fillets on a 20 -y time horizon, an adjustment of $\pm 50 \%$ (from the mean value of 30 days) storage resulted in changes of $\pm 8.33 \times 10^{-2}, \pm 1.09 \times 10^{-1}$, and $\pm 8.40 \times$ $10^{-2} \mathrm{~kg} \mathrm{CO}_{2} \mathrm{e} \mathrm{kg} \mathrm{product}{ }^{-1}$ (Figures S9A-C) which resulted percent changes of $\pm 15 \%, \pm 17 \%$, and $\pm 15 \%$ for the German, Netherlands, and domestic markets, respectively. In the case of crab-flavored sticks on a 20$\mathrm{y}$ time horizon, an adjustment storage time resulted in changes of $\pm 1.10 \times 10^{-1}, \pm 9.53 \times 10^{-2}$, and $\pm 8.42 \mathrm{x}$ $10^{-2} \mathrm{~kg} \mathrm{CO}_{2} \mathrm{e} \mathrm{kg} \mathrm{product}{ }^{-1}$ (Figures S9D-F) which resulted in percent changes of $\pm 17 \%, \pm 16 \%$, and $\pm 15 \%$ for the Japanese, South Korean, and domestic markets, respectively. In the case of battered-and-breaded fillets on a 100-y time horizon, an adjustment storage time resulted in changes of $\pm 9.38 \times 10^{-2}, \pm 1.14 \times 10^{-}$ ${ }^{1}$, and $\pm 9.70 \times 10^{-2} \mathrm{~kg} \mathrm{CO}_{2} \mathrm{e} \mathrm{kg} \mathrm{product}{ }^{-1}$ (Figures S9G-I) for percent changes of $\pm 16 \%, \pm 17 \%$, and $\pm 16 \%$ for the German, Netherlands, and domestic markets, respectively. In the case of crab-flavored sticks on a 100 -y time horizon, an adjustment storage time resulted in changes of $\pm 1.14 \times 10^{-1}, \pm 1.06 \times 10^{-1}$, and $\pm 9.71 \times 10^{-2} \mathrm{~kg} \mathrm{CO}_{2} \mathrm{e} \mathrm{kg} \mathrm{product}{ }^{-1}$ (Figures S9J-L) for percent changes of $\pm 17 \%, \pm 17 \%$, and $\pm 16 \%$ for the Japanese, South Korean, and domestic markets, respectively.

Second, we considered the choice of non-electricity emission factors for the ingredients and materials. In the case of battered-and-breaded fillets on a 20-y time horizon, the alternative emission factors resulted in an increase of $4.66 \times 10^{-2}$ for all markets (Figures S9A-C), which resulted in values of $6.09 \times 10^{-1}, 6.98 \times$ $10^{-1}$, and $6.11 \times 10^{-1} \mathrm{~kg} \mathrm{CO}_{2} \mathrm{e} \mathrm{kg} \mathrm{product}{ }^{-1}$, and percent change decreases of $11 \%, 11 \%$, and $12 \%$ for the German, Netherlands, and domestic markets, respectively. In the case of crab-flavored sticks on a $20-y$ time horizon, the alternative emission factors resulted in a decrease of $6.82 \times 10^{-2} \mathrm{~kg} \mathrm{CO}_{2} \mathrm{e} \mathrm{kg}$ product ${ }^{-1}$ for all markets (Figures S9D-F) which resulted in values of $5.78 \times 10^{-1}, 5.26 \times 10^{-1}$, and $4.78 \times 10^{-1} \mathrm{~kg}$ $\mathrm{CO}_{2} \mathrm{e} \mathrm{kg} \mathrm{product}{ }^{-1}$, and percent change decreases of $11 \%, 11 \%$, and $12 \%$ for the Japanese, South Korean, and domestic markets, respectively. In the case of battered-and-breaded fillets on a 100-y time horizon, the alternative emission factors resulted in an increase of $8.65 \times 10^{-3} \mathrm{~kg} \mathrm{CO}_{2} \mathrm{e} \mathrm{kg} \mathrm{product}{ }^{-1}$ for all markets (Figures S9G-I) which resulted in values of $6.12 \times 10^{-1}, 6.82 \times 10^{-1}$, and $6.23 \times 10^{-1} \mathrm{~kg} \mathrm{CO}_{2} \mathrm{e} \mathrm{kg} \mathrm{product}^{-1}$, and percent change decreases of $1.4 \%, 1.3 \%$, and $1.4 \%$ for the German, Netherlands, and domestic markets, respectively. In the case of crab-flavored sticks on a $100-\mathrm{y}$ time horizon, the alternative emission factors resulted in a decrease of $7.72 \times 10^{-2} \mathrm{~kg} \mathrm{CO}_{2} \mathrm{e} \mathrm{kg} \mathrm{product}^{-1}$ for all markets (Figures S9J-L) which resulted in values of $5.85 \times 10^{-1}, 5.54 \times 10^{-1}$, and $5.24 \times 10^{-1} \mathrm{~kg} \mathrm{CO}_{2} \mathrm{e} \mathrm{kg} \mathrm{product}{ }^{-1}$, and percent change decreases of $12 \%, 12 \%$, and $13 \%$ for the Japanese, South Korean, and domestic markets, respectively. 


\section{S4.5 Sensitivity analysis of the transport to retail phase of the seafood supply-chain}

\section{S4.5.1 Sensitivity analysis of parameters included in the standard deviation}

In the case of products (packaged frozen battered-and-breaded fillets and packaged frozen crab-flavored sticks) for export markets (Germany, Netherlands, Japan, and South Korea), on both time horizons, the top contributors to variance in the standard deviations were the mass of the intermediary product (frozen fillet or frozen surimi) for each market, the mass of the at-sea pollock catch, and the mass of the pollock caught by the AFA fleet (Figures S10A, S10B, S10D, S10E, S10G, S10H, S10J, and S10K). In the case of domestic frozen battered-and-breaded fillets on a 20 -y time horizon, the top contributors to variance in the standard deviations were the mass of surimi to the domestic market, shipping SOx GWP, and the shipping NOx GWP (Figure S10C). In the case of products for the domestic market, the top contributors to variance in the standard deviations were mass of surimi to the domestic market, shipping SOx GWP, and the shipping NOx GWP (Figure S10F).

\section{S4.5.2 Sensitivity analysis of highly uncertain parameters}

In the case of highly uncertain variables, the heavy-duty truck distance from the processor to the retail distribution center, the global GWP instead of the shipping GWP, and ship HFO sulfur levels had the largest impact on the baseline values (Figure S11).

First, we considered the results of using the minimum truck distance from the processor to the retail distribution center $(391 \mathrm{~km})$ instead of the distances used in the baseline scenarios (Table S11). In the case of frozen packaged crab-flavored sticks on a 20 -y time horizon, the baseline values $\left(1.31 \times 10^{-1}, 5.05\right.$ $\mathrm{x} 10^{-2}$, and $2.01 \times 10^{-1} \mathrm{~kg} \mathrm{CO}_{2} \mathrm{e} \mathrm{kg} \mathrm{product}{ }^{-1}$, and for the Japanese, South Korean, and domestic markets, respectively) decreased by $8.08 \times 10^{-2}$ and $2.52 \times 10^{-1} \mathrm{~kg} \mathrm{CO}_{2} \mathrm{e} \mathrm{kg} \mathrm{product}{ }^{-1}$ (Figures S11D and S11F) which resulted in values of $5.05 \times 10^{-2}$ and $-5.09 \times 10^{-2} \mathrm{~kg} \mathrm{CO}_{2} \mathrm{e} \mathrm{kg} \mathrm{product}{ }^{-1}$, and a decrease of $62 \%$ and $125 \%$ from the baseline values for the Japanese and domestic markets, respectively. In the case of frozen packaged crab-flavored sticks on a 100-y time horizon, the baseline values $\left(1.20 \times 10^{-1}, 4.82 \times 10^{-2}\right.$, and $2.65 \times 10^{-1} \mathrm{~kg} \mathrm{CO}_{2} \mathrm{e} \mathrm{kg} \mathrm{product}{ }^{-1}$ for the Japanese, South Korean, and domestic markets, respectively) decreased by $7.40 \times 10^{-2}$ and $2.32 \times 10^{-1} \mathrm{~kg} \mathrm{CO}_{2} \mathrm{e} \mathrm{kg} \mathrm{product}{ }^{-1}$ (Figures S11J and S11L) which resulted in values of $4.63 \times 10^{-2}$ and $3.25 \times 10^{-2} \mathrm{~kg} \mathrm{CO}_{2} \mathrm{e} \mathrm{kg} \mathrm{product}{ }^{-1}$, and a decrease of $62 \%$ and $87 \%$ from the baseline values for the Japanese and domestic markets, respectively. There was no change in the South Korean market baseline value because we did not change the distance traveled by the heavy-duty truck in this instance. In the case of frozen packaged battered-and-breaded fillets on a 20 -y time horizon, the baseline values $\left(1.94 \times 10^{-1}, 1.96 \times 10^{-1}\right.$, and $1.66 \times 10^{-1} \mathrm{~kg} \mathrm{CO}_{2} \mathrm{e} \mathrm{kg} \mathrm{product}{ }^{-1}$ for the German, Netherlands, and domestic markets, respectively) decreased by $1.43 \times 10^{-1}, 1.45 \times 10^{-1}$, and $2.22 \times 10^{-1} \mathrm{~kg}$ $\mathrm{CO}_{2} \mathrm{e} \mathrm{kg} \mathrm{product}{ }^{-1}$ (Figures S11A-C) which resulted in values of $5.05 \times 10^{-2}, 5.10 \times 10^{-2}$, and $-5.58 \times 10^{-2}$ 
$\mathrm{kg} \mathrm{CO}_{2} \mathrm{e} \mathrm{kg} \mathrm{product}{ }^{-1}$ and a decrease of $74 \%, 74 \%$ and $134 \%$ from the baseline values for the German, Netherlands, and domestic markets, respectively. In the case of frozen packaged crab-flavored sticks on a 100 -y time horizon, the baseline values $\left(1.77 \times 10^{-1}, 1.79 \times 10^{-1}\right.$, and $2.66 \times 10^{-1} \mathrm{~kg} \mathrm{CO}_{2} \mathrm{e} \mathrm{kg} \mathrm{product}^{-1}$ for the German, Netherlands, and domestic markets, respectively) decreased by $1.31 \times 10^{-1}, 1.32 \times 10^{-1}$, and $2.31 \times 10^{-1} \mathrm{~kg} \mathrm{CO}_{2} \mathrm{e} \mathrm{kg} \mathrm{product}{ }^{-1}$ (Figures S11G-I) which resulted in values of $4.62 \times 10^{-2}, 4.65 \times 10^{-2}$, $3.44 \times 10^{-2} \mathrm{~kg} \mathrm{CO}_{2} \mathrm{e} \mathrm{kg} \mathrm{product}{ }^{-1}$, and a decrease of $74 \%, 74 \%$, and $87 \%$ from baseline values for the German, Netherlands, and domestic markets, respectively.

Second, we considered the results of using the maximum truck distance from the processor to the retail distribution center $(2,341 \mathrm{~km})$ instead of the distances used in the baseline scenarios (Table S11). In the case of frozen packaged battered-and-breaded fillets on a 20 -y time horizon, the increase in distance resulted in increases of $1.09 \times 10^{-1}$ and $1.10 \times 10^{-1} \mathrm{~kg} \mathrm{CO}_{2} \mathrm{e} \mathrm{kg} \mathrm{product}{ }^{-1}$ (Figures S11A and S11B) for the values of $3.03 \times 10^{-1}$ and $3.05 \times 10^{-1} \mathrm{~kg} \mathrm{CO}_{2} \mathrm{e} \mathrm{kg} \mathrm{product}^{-1}$, and an increase of $56 \%$ from the baseline values for the German and Netherlands markets, respectively. In the case of frozen packaged crabflavored sticks on a 20-y time horizon, the increase in distance resulted in increases of $1.71 \times 10^{-1}$ and $2.52 \times 10^{-1} \mathrm{~kg} \mathrm{CO}_{2} \mathrm{e} \mathrm{kg} \mathrm{product}{ }^{-1}$ (Figures S11D and S11E) which resulted in values of $3.03 \times 10^{-1}$ and $3.02 \times 10^{-1} \mathrm{~kg} \mathrm{CO}_{2} \mathrm{e} \mathrm{kg} \mathrm{product}{ }^{-1}$ and an increase of $130 \%$ and $499 \%$ from the baseline values for the Japanese and South Korean markets, respectively. In the case of frozen packaged battered-and-breaded fillets on a 100-y time horizon, the increase in distance resulted in increases of $9.94 \times 10^{-2}$ and $1.00 \times 10^{-1}$ $\mathrm{kg} \mathrm{CO}_{2} \mathrm{e} \mathrm{kg} \mathrm{product}{ }^{-1}$ (Figures $\mathrm{S} 11 \mathrm{G}$ and $\mathrm{S} 11 \mathrm{H}$ ) which resulted in values of $2.77 \times 10^{-1}$ and $2.79 \times 10^{-1} \mathrm{~kg}$ $\mathrm{CO}_{2} \mathrm{e} \mathrm{kg} \mathrm{product}{ }^{-1}$ and increases of $56 \%$ from the baseline values for the German and Netherlands markets, respectively. In the case of frozen packaged crab-flavored sticks on a 100-y time horizon, the increase in distance resulted in increases of $1.57 \times 10^{-1}$ and $2.41 \times 10^{-1} \mathrm{~kg} \mathrm{CO}_{2} \mathrm{e} \mathrm{kg} \mathrm{product}{ }^{-1}$ (Figures S11 J and $\mathrm{S} 11 \mathrm{~K}$ ) which resulted in values of $2.77 \times 10^{-1}$ and $2.89 \times 10^{-1} \mathrm{~kg} \mathrm{CO}_{2} \mathrm{e} \mathrm{kg}$ product ${ }^{-1}$ and an increase of $130 \%$ and $499 \%$ from the baseline values for the Japanese and South Korean markets, respectively. There was no change in the domestic market baseline value because we did not change the distance traveled by the heavy-duty truck in this instance.

Third, we considered the global metric GWP used as an alternative to the shipping GWP. Here, we only considered products for the domestic market because we assume the products for other markets do not undergo transport by container ship during this phase of the seafood supply-chain. In comparison to the shipping GWP, on a 20-y time horizon, the global metric GWP has percent differences of $-124 \%,-17.5 \%$, $+4.5 \%$, and $-63.7 \%$ for $\mathrm{NOx}, \mathrm{SO}_{2}, \mathrm{BC}$, and $\mathrm{OC}$, respectively. Using the global metric GWP instead of the shipping GWP, for battered-and-breaded fillets, resulted in increases of baseline values by $1.27 \times 10^{-1}$ and $4.29 \times 10^{-2} \mathrm{~kg} \mathrm{CO}_{2} \mathrm{e} \mathrm{kg} \mathrm{product}{ }^{-1}$ (Figures S11C and S11I). These increases resulted in net values of 2.93 
x $10^{-1}$ and $3.08 \times 10^{-1} \mathrm{~kg} \mathrm{CO}_{2} \mathrm{e} \mathrm{kg} \mathrm{product}{ }^{-1}$ and an increase of $77 \%$ and $16 \%$ from the baseline values for the 20 -y and 100-y time horizons, respectively. In comparison to the shipping GWP, on a 100-y time horizon, the global metric GWP has percent differences of $-74 \%,-17.4 \%,+1.4 \%$, and $-64.3 \%$ for NOx, $\mathrm{SO}_{2}, \mathrm{BC}$, and $\mathrm{OC}$, respectively. Using the global metric GWP instead of the shipping GWP, for crabflavored sticks, resulted increases of baseline values by $1.31 \times 10^{-1}$ and $4.68 \times 10^{-2} \mathrm{~kg} \mathrm{CO}_{2} \mathrm{e} \mathrm{kg} \mathrm{product}{ }^{-1}$ (Figures S11F and S11L). These increases resulted in net values of $3.33 \times 10^{-1}$ and $3.12 \times 10^{-1} \mathrm{~kg} \mathrm{CO}_{2} \mathrm{e} \mathrm{kg}$ product $^{-1}$ and an increase of $65 \%$ and $15 \%$ from the baseline values for the $20-\mathrm{y}$ and $100-\mathrm{y}$ time horizons, respectively.

Lastly, we consider the reduction of the maximum allowable sulfur level in marine fuels from 3.5 (\%wt.) to 0.5 (\% wt.). Here, we only consider products for the domestic market because we assume the products for other markets do not undergo transport by container ship during this phase of the seafood supplychain. In the case of battered-and-breaded fillets, decreasing the sulfur level in HFO by $86 \%$ resulted in increases of $2.75 \times 10^{-1}$ and $2.85 \times 10^{-1} \mathrm{~kg} \mathrm{CO}_{2} \mathrm{e} \mathrm{kg} \mathrm{product}{ }^{-1}$, and an increase of $37 \%$ and $7.5 \%$ over the baseline value for the 20-y and 100-y time horizons, respectively. In the case of crab-flavored sticks, reducing sulfur levels resulted in increases of $7.40 \times 10^{-2}$ and $1.99 \times 10^{-2} \mathrm{~kg} \mathrm{CO}_{2} \mathrm{e} \mathrm{kg} \mathrm{product}{ }^{-1}$ (Figures $\mathrm{S} 11 \mathrm{~F}$ and $\mathrm{S} 11 \mathrm{~K}$ ) which resulted in values of $2.75 \times 10^{-1}$ and $2.85 \times 10^{-1} \mathrm{~kg} \mathrm{CO}_{2} \mathrm{e} \mathrm{kg} \mathrm{product}{ }^{-1}$, which is an increase of $37 \%$ and $7.5 \%$ over the baseline value for the 20 -y and $100-y$ time horizons, respectively.

\section{S4.6 Sensitivity analysis of the retail phase of the seafood supply-chain}

\section{S4.6.1 Sensitivity analysis of parameters included in the standard deviation}

In all cases (both products, all retail markets, and both time horizons), the top contributors to variance were the mass of the intermediary product (frozen fillet or frozen surimi), the mass of the at-sea pollock catch, and the mass of the pollock caught by the AFA fleet (Figure S12)

\section{S4.6.2 Sensitivity analysis of highly uncertain parameters}

In the case of highly uncertain variables, the number of days the products spend in storage at the retail distribution center, the electricity consumption for ancillary operations, and the fraction of ancillary electricity consumption not allocated to refrigeration had the largest impact on the baseline values (Figure S12).

First, we considered the number of days the product spends in storage ( \pm 5 days at the retail distribution center, \pm 3 days at the retail store, and \pm 3 days in the display case). In the case of battered-and-breaded fillets on a 20 -y time horizon, an adjustment of in the storage time ( $\pm 50 \%$ in the time in storage at the retail distribution center and an increase $\pm 43 \%$ of time in both retail storage and retail display) resulted in changes of $\pm 6.70 \times 10^{-3}, \pm 8.50 \times 10^{-3}$, and $\pm 6.75 \times 10^{-3} \mathrm{~kg} \mathrm{CO}_{2} \mathrm{e} \mathrm{kg} \mathrm{product}{ }^{-1}$ for the German, Netherlands, 
and domestic markets, respectively (Figures S12A-C) which resulted in percent changes of $\pm 30 \%$ for all markets. In the case of crab-flavored sticks on a 20 -y time horizon, an adjustment of the time in storage resulted in changes of $\pm 9.34 \times 10^{-3}, \pm 1.23 \times 10^{-2}$, and $\pm 1.46 \times 10^{-2} \mathrm{~kg} \mathrm{CO}_{2} \mathrm{e} \mathrm{kg} \mathrm{product}{ }^{-1}$ for the Japanese, South Korean, and domestic markets, respectively (Figures S12D-F) and a percent change of $\pm 30 \%$ for all markets. In the case of battered-and-breaded fillets on a 100-y time horizon, an adjustment of the time in storage resulted in changes of $\pm 7.13 \times 10^{-3}, \pm 8.54 \times 10^{-3}$, and $\pm 7.35 \times 10^{-3} \mathrm{~kg} \mathrm{CO}_{2} \mathrm{e} \mathrm{kg} \mathrm{product}{ }^{-1}$ for the German, Netherlands, and domestic markets, respectively (Figures S12G-I) and a percent change of $\pm 30 \%$ for all markets. In the case of crab-flavored sticks on a 100-y time horizon, an adjustment of the time in storage resulted in changes of $\pm 1.49 \times 10^{-2}, \pm 1.67 \times 10^{-2}$, and $\pm 1.64 \times 10^{-2} \mathrm{~kg} \mathrm{CO}_{2} \mathrm{e} \mathrm{kg} \mathrm{product}{ }^{-1}$ for the Japanese, South Korean, and domestic markets, respectively (Figures S12J-L) and a percent changes of $\pm 30 \%$ for all markets.

Second, we considered the electricity consumption of ancillary operations at the retail store. In the case of battered-and-breaded fillets on a 20 -y time horizon, adjustment of $\pm 28 \%\left( \pm 325 \mathrm{kWh} \mathrm{m}^{-2} \mathrm{y}^{-1}\right)$ resulted in changes of $\pm 2.68 \times 10^{-3}, \pm 3.75 \times 10^{-3}$, and $\pm 2.88 \times 10^{-3} \mathrm{~kg} \mathrm{CO}_{2} \mathrm{e} \mathrm{kg} \mathrm{product}{ }^{-1}$ for the German, Netherlands, and domestic markets, respectively (Figures S12A-C) which resulted in percent changes of $\pm 13 \%$ for all markets. In the case of crab-flavored sticks on a 20-y time horizon, an adjustment of ancillary operations electricity consumption rate resulted in changes of $\pm 3.76 \times 10^{-3}, \pm 3.27 \times 10^{-3}$, and $\pm 2.89 \times 10^{-3} \mathrm{~kg} \mathrm{CO}_{2} \mathrm{e} \mathrm{kg}$ product $^{-1}$ for the Japanese, South Korean, and domestic markets, respectively (Figures S12D-F) and a percent change of roughly $\pm 14 \%$ for all markets. In the case of battered-and-breaded fillets on a 100 -y time horizon, an adjustment of ancillary operations electricity consumption rate resulted in changes of $\pm 3.22 \times 10^{-3}, \pm 3.91 \times 10^{-3}$, and $\pm 3.32 \times 10^{-3} \mathrm{~kg} \mathrm{CO}_{2} \mathrm{e} \mathrm{kg} \mathrm{product}{ }^{-1}$ for the German, Netherlands, and domestic markets, respectively (Figures S12G-I) and a percent change of roughly $\pm 14 \%$ for all markets. In the case of crab-flavored sticks on a 100-y time horizon, an adjustment of ancillary operations electricity consumption rate resulted in changes of $\pm 3.92 \times 10^{-3}, \pm 3.62 \times 10^{-3}$, and $\pm 3.33 \times 10^{-3} \mathrm{~kg} \mathrm{CO}_{2} \mathrm{e} \mathrm{kg}$ product $^{-1}$ (Figures S12J-L) and a percent changes of $\pm 15 \%, \pm 15 \%$, and $\pm 14 \%$ for the Japanese, South Korean, and domestic markets, respectively.

Third, we considered the electricity consumption of ancillary operations at the retail store not allocated to refrigeration. In the case of battered-and-breaded fillets on a 20 -y time horizon, adjustment of $\pm 28 \%( \pm 0.15$ from the baseline of 0.55$)$ resulted in changes of $\pm 2.82 \times 10^{-3}, \pm 3.70 \times 10^{-3}$, and $\pm 2.84 \times 10^{-3}$ $\mathrm{kg} \mathrm{CO}_{2} \mathrm{e} \mathrm{kg} \mathrm{product}{ }^{-1}$ for the German, Netherlands, and domestic markets, respectively (Figures S12A-C) which resulted in percent changes of $\pm 13 \%$ for all markets. In the case of crab-flavored sticks on a 20 -y time horizon, an adjustment of ancillary operations electricity consumption not allocated to refrigeration resulted in changes of $\pm 3.71 \times 10^{-3}, \pm 3.22 \times 10^{-3}$, and $\pm 2.84 \times 10^{-3} \mathrm{~kg} \mathrm{CO}_{2} \mathrm{e} \mathrm{kg} \mathrm{product}{ }^{-1}$ for the Japanese, 
South Korean, and domestic markets, respectively (Figures S12D-F) and a percent change of roughly $\pm 14 \%$ for all markets. In the case of battered-and-breaded fillets on a 100 -y time horizon, an adjustment of ancillary operations electricity consumption not allocated to refrigeration resulted in changes of \pm 3.17 $\times 10^{-3}, \pm 3.86 \times 10^{-3}$, and $\pm 3.28 \times 10^{-3} \mathrm{~kg} \mathrm{CO}_{2} \mathrm{e} \mathrm{kg} \mathrm{product}{ }^{-1}$ (Figures S12G-I) and a percent change of $\pm 13 \%, \pm 14 \%$, and $\pm 13 \%$ for the German, Netherlands, and domestic markets, respectively. In the case of crab-flavored sticks on a 100-y time horizon, an adjustment of ancillary operations electricity consumption not allocated to refrigeration resulted in changes of $\pm 3.87 \times 10^{-3}, \pm 3.57 \times 10^{-3}$, and $\pm 3.28 \times$ $10^{-3} \mathrm{~kg} \mathrm{CO}_{2} \mathrm{e} \mathrm{kg}$ product $^{-1}$ (Figures S12J-L) and a percent changes of $\pm 15 \%, \pm 15 \%$, and $\pm 14 \%$ for the Japanese, South Korean, and domestic markets, respectively.

\section{S4.7 Sensitivity analysis of the sum total of the seafood supply-chain}

\section{S4.7.1 Sensitivity analysis of parameters included in the standard deviation}

The top contributors to variance depend on the product (packaged frozen crab-flavored sticks or packaged frozen breaded-and-battered fillets) and the time horizon (20-y or 100-y) (Figure S13).

In the case of both products on a 20 -y time horizon, the top contributors the variance were the mass of the intermediary product (frozen surimi or frozen fillets), the shipping GWPs of SLCF pollutants (NOx, SOx, $\mathrm{BC}$, and $\mathrm{OC}$ ), and the $\mathrm{BC}$ emission factor (applied to the emissions of the fishing vessel) (Figures S13AF).

In the case of both products on a 100-y time horizon, the top contributors the variance were the mass of the intermediary product (frozen surimi or frozen fillets), the shipping GWPs of SLCF pollutants (NOx, SOx, BC, and OC), the fuel consumption of the container ship, and the mass of the at-sea pollock catch (Figures S13G-L).

\section{S4.7.2 Sensitivity analysis of highly uncertain parameters}

In the case of highly uncertain variables, the parameters that have the largest impact on the net climate forcing values depend on the market and the time horizon (Figure S14). Across all markets and time horizons, using the global mean metric GWP instead of the shipping GWP, had the largest impact. For battered-and-breaded fillets to European markets on a 20-y time horizon, reducing the sulfur level in marine fuel to 0.5 (\% wt.) was second in order of impact, and the variance in the sulfur level in marine fuel was third in order of impact. In all other cases, the distances traveled by heavy-duty trucks was second in order of impact, and the number of days the products spend in storage was third in order of impact.

First, we considered the global metric GWP used as an alternative to the shipping GWP. In comparison to the shipping GWP, on a 20 -y time horizon, the global metric GWP has percent differences of - $124 \%$, - 
$17.5 \%,+4.5 \%$, and $-63.7 \%$ for $\mathrm{NOx}, \mathrm{SO}_{2}, \mathrm{BC}$, and $\mathrm{OC}$, respectively. Using the global metric GWP instead of the shipping GWP, on a 20-y time horizon, resulted in the baseline value $(0.72,0.82$, and 1.16 $\mathrm{kg} \mathrm{CO}_{2} \mathrm{e} \mathrm{kg} \mathrm{product}{ }^{-1}$ for the German, Netherlands, and domestic market, respectively) increases of 1.22, 1.21, and 0.90 (Figures S14A-C). These increases resulted in net values of 1.94, 2.03, and $2.06 \mathrm{~kg} \mathrm{CO}_{2} \mathrm{e}$ $\mathrm{kg} \mathrm{product}^{-1}$, and an increase of 169,148 , and $78 \%$ over the baseline value for the German, Netherlands, and domestic markets, respectively. In the case of crab-flavored sticks on a $20-y$ time horizon, the baseline values $\left(1.07,0.92\right.$. and $1.16 \mathrm{~kg} \mathrm{CO}_{2} \mathrm{e} \mathrm{kg} \mathrm{product}{ }^{-1}$ for the Japanese and South Korean, and domestic markets respectively) increased by $0.84,0.86$, and 0.87 (Figures S14D-F). These increases resulted in net values of $1.92,1.78,2.03 \mathrm{~kg} \mathrm{CO}_{2} \mathrm{e} \mathrm{kg}$ product ${ }^{-1}$, and increases over the baseline value of 79,93 , and $74 \%$ for the Japanese, South Korean, and domestic markets, respectively. In comparison to the shipping GWP, on a 100-y time horizon, the global metric GWP has percent differences of -74\%, $17.4 \%,+1.4 \%$, and $-64.3 \%$ for $\mathrm{NOx}, \mathrm{SO}_{2}, \mathrm{BC}$, and $\mathrm{OC}$, respectively. Using the global metric GWP instead of the shipping GWP, on a 100-y time horizon, resulted in the baseline value $(1.15,1.22$, and 1.32 $\mathrm{kg} \mathrm{CO}_{2} \mathrm{e} \mathrm{kg} \mathrm{product}{ }^{-1}$ for the German, Netherlands, and domestic market, respectively) increases of 0.43 , 0.43 , and 0.32 (Figures S14G-I). These increases resulted in net values of $1.58,1.65$, and $1.64 \mathrm{~kg} \mathrm{CO}_{2} \mathrm{e} \mathrm{kg}$ product $^{-1}$, and an increase of 38,35 , and $24 \%$ over the baseline value for the German, Netherlands, and domestic markets, respectively. In the case of crab-flavored sticks on a 100-y time horizon, the baseline values $\left(1.18,1.08\right.$, and $1.29 \mathrm{~kg} \mathrm{CO}_{2} \mathrm{e} \mathrm{kg} \mathrm{product}^{-1}$ for the Japanese and South Korean, and domestic markets respectively) increased by $0.30,0.31$, and 0.31 (Figures S14J-L). These increases resulted in net values of $1.49,1.38$, and $1.60 \mathrm{~kg} \mathrm{CO}_{2} \mathrm{e} \mathrm{kg}$ product $^{-1}$, and increases over the baseline value of 26, 29, and $24 \%$ for the Japanese and South Korean, respectively.

Second, we considered the reduction of the maximum allowable sulfur level in marine fuels by from 3.5 (\%wt.) to 0.5 (\% wt.). In the case of battered-and-breaded fillets on a 20 -y time horizon, decreasing the sulfur level in HFO by $86 \%$ resulted in increases in of $0.36,0.36$, and $0.07 \mathrm{~kg} \mathrm{CO}_{2} \mathrm{e} \mathrm{kg} \mathrm{product}{ }^{-1}$ (Figures S14A-C) which resulted in net values of $1.09,1.19$, and $1.23 \mathrm{~kg} \mathrm{CO}_{2} \mathrm{e} \mathrm{kg}$ product ${ }^{-1}$, and increases of 50, 44 , and $6 \%$ over the baseline value for the German, Netherlands, and domestic markets, respectively. In the case of crab-flavored sticks on a 20 -y time horizon, decreasing the sulfur level resulted in increases in of $0.09,0.10$, and $0.07 \mathrm{~kg} \mathrm{CO}_{2} \mathrm{e} \mathrm{kg}$ product $^{-1}$ (Figures S14D-F) which resulted in net values of 1.16, 1.03, and $1.11 \mathrm{~kg} \mathrm{CO}_{2} \mathrm{e} \mathrm{kg} \mathrm{product}{ }^{-1}$, and increases of 9, 11, and $6 \%$ over the baseline value for the Japanese and South Korean markets, respectively. In the case of battered-and-breaded fillets on a 100-y time horizon, decreasing the sulfur level resulted in increases in of $0.10,0.10$, and $1.98 \times 10^{-2} \mathrm{~kg} \mathrm{CO}_{2} \mathrm{e} \mathrm{kg}$ product $^{-1}$ (Figures S14G-I) which resulted in net values of 1.24, 1.32, and $1.34 \mathrm{~kg} \mathrm{CO}_{2} \mathrm{e} \mathrm{kg}$ product ${ }^{-1}$, and increases of 8,8 , and $1 \%$ over the baseline value for the German, Netherlands, and domestic markets, 
respectively. In the case of crab-flavored sticks on a 100-y time horizon, decreasing the sulfur level resulted in increases in of $2.50 \times 10^{-2}, 2.73 \times 10^{-2}$, and $2.43 \times 10^{-3} \mathrm{~kg} \mathrm{CO}_{2} \mathrm{e} \mathrm{kg}$ product $^{-1}$ (Figures S14J-L) which resulted in net values of 1.21, 1.10, and $1.29 \mathrm{~kg} \mathrm{CO}_{2} \mathrm{e} \mathrm{kg} \mathrm{product}{ }^{-1}$, and increases of 2, 3, and 1.89 x $10^{-3} \%$ over the baseline value for the Japanese and South Korean markets, respectively.

Third, we considered the range of sulfur levels in marine fuels which varies \pm 1.1 (\% wt.) from the mean value of 2.4 (\%wt.). In the case of battered-and-breaded fillets on a 20 -y time horizon, adjusting the sulfur level in HFO by $\pm 46 \%$ resulted in differences of $\pm 0.23, \pm 0.23$, and $\pm 0.05 \mathrm{~kg} \mathrm{CO}_{2} \mathrm{e} \mathrm{kg}$ product $^{-1}$ (Figures S14A-C) which resulted in a difference of $\pm 32,28$, and $4 \%$ over the baseline for the German, Netherlands, and domestic markets, respectively. In the case of crab-flavored sticks on a 20 -y time horizon, adjusting the sulfur level in HFO resulted in differences of $\pm 0.09, \pm 0.10$, and $\pm 0.07 \mathrm{~kg} \mathrm{CO}_{2} \mathrm{e} \mathrm{kg}$ product $^{-1}$ (Figures S14D-F) which resulted in differences of $\pm 9,11$, and $6 \%$ over the baseline value for the Japanese, South Korean, and domestic markets, respectively. In the case of battered-and-breaded fillets on a 100-y time horizon, adjusting the sulfur level in HFO resulted in differences of $\pm 0.06, \pm 0.06$, and \pm 0.01 $\mathrm{kg} \mathrm{CO}_{2} \mathrm{e} \mathrm{kg} \mathrm{product}{ }^{-1}$ (Figures S14G-I) which resulted in differences of $\pm 6,5$, and $1 \%$ over the baseline over the baseline value for the German, Netherlands, and domestic markets, respectively. In the case of crab-flavored sticks on a 100-y time horizon, adjusting the sulfur level resulted in differences of \pm 0.02 , \pm 0.02 , and $\pm 0.01 \mathrm{~kg} \mathrm{CO}_{2} \mathrm{e} \mathrm{kg} \mathrm{product}{ }^{-1}$ (Figures S14J-L) which resulted in differences of \pm 1 , 2, and $1 \%$ over the baseline over the baseline value for the Japanese, South Korean, and domestic markets, respectively.

Fourth, we considered decreasing the distances traveled by heavy-duty trucks. In the case of battered-andbreaded fillets for the German market, we considered a combined decrease of $76 \%$ in the distance traveled by heavy-duty trucks $(2.50 \mathrm{~km}$ instead of the baseline value of $167 \mathrm{~km}$; and $391 \mathrm{~km}$ instead of the baseline of 1,500 km). This decrease in distance for the German market resulted in combined decreases in climate forcing of 0.15 and $0.14 \mathrm{~kg} \mathrm{CO}_{2} \mathrm{e} \mathrm{kg}$ product ${ }^{-1}$ (Figures S14A and S14F) and combined percent decreases of $21 \%$ and $12 \%$ for the 20 -y and 100 -y time horizons, respectively. In the case of battered-and-breaded fillets for the Netherlands market, we considered a combined decrease of $77 \%$ in the distance traveled by heavy-duty trucks $(2.50 \mathrm{~km}$ instead of the baseline value of $179 \mathrm{~km}$; and $391 \mathrm{~km}$ instead of the baseline of 1,500 km). This decrease in distance for the Netherlands market resulted in combined decreases in climate forcing of 0.15 and $0.14 \mathrm{~kg} \mathrm{CO}_{2} \mathrm{e} \mathrm{kg}$ product $^{-1}$ (Figures S14B and $\mathrm{S} 14 \mathrm{G}$ ) and combined percent decreases of $18 \%$ and $11 \%$ for the 20 -y and $100-\mathrm{y}$ time horizons, respectively. In the case of battered-and-breaded fillets for the domestic market, we considered a combined decrease of $83 \%$ in the distance traveled by heavy-duty trucks $(2.50 \mathrm{~km}$ instead of the baseline value of $16.9 \mathrm{~km}$; and $391 \mathrm{~km}$ instead of the baseline of 2,340 km). This decrease in distance for the 
domestic market resulted in combined decreases in climate forcing of 0.22 and $0.23 \mathrm{~kg} \mathrm{CO}_{2} \mathrm{e} \mathrm{kg} \mathrm{product}{ }^{-1}$ (Figures S14C and S14H) and combined percent decreases of $19 \%$ and $17 \%$ for the $20-\mathrm{y}$ and $100-\mathrm{y}$ time horizons, respectively. In the case of crab-flavored sticks for the Japanese market, we considered a combined decrease of $62 \%$ in the distance traveled by heavy-duty trucks $(2.50 \mathrm{~km}$ instead of the baseline value of $12.5 \mathrm{~km}$; and $391 \mathrm{~km}$ instead of the baseline of $1,016 \mathrm{~km}$ ). This decrease in distance for the Japanese market resulted in combined decreases in climate forcing of 0.08 and $0.07 \mathrm{~kg} \mathrm{CO}_{2} \mathrm{e} \mathrm{kg} \mathrm{product}{ }^{-1}$ (Figures S14D and S14J) and combined percent decreases of $7.5 \%$ and $5.9 \%$ for the $20-\mathrm{y}$ and $100-\mathrm{y}$ time horizons, respectively. In the case of crab-flavored sticks for the South Korean market, there was no change in the net climate forcing because we did not adjust the distances downward. In the case of crabflavored sticks for the domestic market, we considered a combined decrease of $83 \%$ in the distance traveled by heavy-duty trucks $(2.50 \mathrm{~km}$ instead of the baseline value of $16.9 \mathrm{~km}$; and $391 \mathrm{~km}$ instead of the baseline of 2,340 km). This decrease in distance for the domestic market resulted in combined decreases in climate forcing of 0.25 and $0.23 \mathrm{~kg} \mathrm{CO}_{2} \mathrm{e} \mathrm{kg}$ product ${ }^{-1}$ (Figures S14F and S14L) and combined percent decreases of $22 \%$ and $18 \%$ for the 20 -y and 100 -y time horizons, respectively.

Fifth, we considered increasing the distances traveled by heavy-duty trucks. In the case of battered-andbreaded fillets for the German market, we considered a combined increase of $56 \%$ in the distance traveled by heavy-duty trucks ( $254 \mathrm{~km}$ instead of the baseline value of $167 \mathrm{~km}$; and 2,341 km instead of the baseline of 1,500 km). This increase in distance for the German market resulted in combined increases in climate forcing of 0.11 and $0.10 \mathrm{~kg} \mathrm{CO}_{2} \mathrm{e} \mathrm{kg} \mathrm{product}{ }^{-1}$ (Figures S14A and S14G) and combined percent decreases of $14 \%$ and $9 \%$ for the 20 -y and 100 -y time horizons, respectively. In the case of battered-andbreaded fillets for the Netherlands market, we considered a combined increase of 55\% in the distance traveled by heavy-duty trucks ( $254 \mathrm{~km}$ instead of the baseline value of $179 \mathrm{~km}$; and 2,341 km instead of the baseline of 1,500 km). This increase in distance for the Netherlands market resulted in combined increases in climate forcing of 0.11 and $0.10 \mathrm{~kg} \mathrm{CO}_{2} \mathrm{e} \mathrm{kg} \mathrm{product}^{-1}$ (Figures S14B and S14H) and combined percent increases of $13 \%$ and $8 \%$ for the 20 -y and 100 -y time horizons, respectively. In the case of battered-and-breaded fillets for the domestic market, we considered a combined increase of $10 \%$ in the distance traveled by heavy-duty trucks ( $254 \mathrm{~km}$ instead of the baseline value of $16.9 \mathrm{~km}$ for transport to secondary processor; no change in distance to retailer). This increase in distance for the domestic market resulted in combined increases in climate forcing of 0.01 and $0.02 \mathrm{~kg} \mathrm{CO}_{2} \mathrm{e} \mathrm{kg} \mathrm{product}^{-1}$ (Figures S14C and S14I) and combined percent decreases of $0.9 \%$ and $1.5 \%$ for the $20-\mathrm{y}$ and 100 -y time horizons, respectively. In the case of crab-flavored sticks for the Japanese market, we considered a combined increase of $152 \%$ in the distance traveled by heavy-duty trucks ( $254 \mathrm{~km}$ instead of the baseline value of $12.5 \mathrm{~km}$; and 2,341 km instead of the baseline of $1,016 \mathrm{~km}$ ). This increase in distance for the 
Japanese market resulted in combined increases in climate forcing of 0.18 and $0.17 \mathrm{~kg} \mathrm{CO}_{2} \mathrm{e} \mathrm{kg} \mathrm{product}{ }^{-1}$ (Figures S14D and S14J) and combined percent increases of $17 \%$ and $18 \%$ for the 20 -y and 100 -y time horizons, respectively. In the case of crab-flavored sticks for the South Korean market, we considered a combined increase of $559 \%$ in the distance traveled by heavy-duty trucks ( $254 \mathrm{~km}$ instead of the baseline value of $2.5 \mathrm{~km}$; and 2,341 km instead of the baseline of $391 \mathrm{~km}$ ). This increase in distance for the South Korean market resulted in combined increases in climate forcing of 0.26 and $0.25 \mathrm{~kg} \mathrm{CO}_{2} \mathrm{e} \mathrm{kg} \mathrm{product}{ }^{-1}$ (Figures S14E and S14K) and combined percent increases of $28 \%$ and $23 \%$ for the $20-\mathrm{y}$ and $100-\mathrm{y}$ time horizons, respectively. In the case of crab-flavored sticks for the domestic market, we considered a combined increase of $10 \%$ in the distance traveled by heavy-duty trucks ( $254 \mathrm{~km}$ instead of the baseline value of $16.9 \mathrm{~km}$ for transport to secondary processor; no change in distance to retailer). This increase in distance for the domestic market resulted in combined increases in climate forcing of $1.02 \times 10^{-2}$ and 9.30 x $10^{-3} \mathrm{~kg} \mathrm{CO}_{2} \mathrm{e} \mathrm{kg}$ product $^{-1}$ (Figures S14F and S14L) and combined percent increases of $0.9 \%$ and $0.7 \%$ for the 20-y and 100-y time horizons, respectively.

Lastly, we considered the impact of storage time on the net climate forcing results (Figure S14). In all cases we considered combined adjustments of $\pm 49 \%$ in storage time over the entire seafood supply-chain ( \pm 56 days from the baseline storage time of 114 days). In the case of breaded-and-battered fillets on a 20y time horizon, the adjustment in storage time resulted in a change of $\pm 0.09, \pm 0.12$, and $\pm 0.09 \mathrm{~kg} \mathrm{CO}_{2} \mathrm{e} \mathrm{kg}$ product $^{-1}$ and increases of $\pm 13 \%, \pm 15 \%$, and \pm 7.8 from baseline values for the German, Netherlands, and domestic markets, respectively. In the case of crab-flavored sticks on a 20 -y time horizon, the adjustment in storage time resulted in a change of $\pm 0.11, \pm 0.13$, and $\pm 0.11 \mathrm{~kg} \mathrm{CO}_{2} \mathrm{e} \mathrm{kg} \mathrm{product}{ }^{-1}$ and increases of $\pm 10 \%, \pm 14 \%$, and \pm 9.5 from baseline values for the Japan, South Korean, and domestic markets, respectively. In the case of breaded-and-battered fillets on a 100-y time horizon, the adjustment in storage time resulted in a change of $\pm 0.11, \pm 0.13$, and $\pm 0.11 \mathrm{~kg} \mathrm{CO}_{2} \mathrm{e} \mathrm{kg} \mathrm{product}{ }^{-1}$ and increases of $\pm 9.6 \%, \pm 11 \%$, and \pm 8.3 from baseline values for the German, Netherlands, and domestic markets, respectively. In the case of crab-flavored sticks on a 100-y time horizon, the adjustment in storage time resulted in a change of $\pm 0.13, \pm 0.12$, and $\pm 0.11 \mathrm{~kg} \mathrm{CO}_{2} \mathrm{e} \mathrm{kg}$ product $^{-1}$ and increases of $\pm 11 \%, \pm 11 \%$, and \pm 8.5 from baseline values for the Japan, South Korean, and domestic markets, respectively. 


\section{Equations (S1 - S17)}

\section{$\mathrm{S} 1$. The mass of metals used in the manufacture and maintenance of the fishing vessels}

We estimated the mass of vessel components $M^{V C}$, (in metric tons) using the following equation:

$$
M_{j, k, l}^{V C}=f_{j, k}^{m a t} \cdot \sum_{l} L S W_{l}
$$

where $f^{m a t}$ is the fraction of material (steel, copper wire, or aluminum), $L S W$ is the light ship weight (in metric tons), $j$ is the component (hull or other structural elements), $k$ is the material of the component (steel, copper wire, and aluminum), and $l$ is the individual vessel.

\section{S2. Vessel width}

We used a linear relationship between the holding capacity and vessel width to estimate the light ship weight (LSW), using the following formula (Fréon et al., 2014):

$$
L S W=-263.81+0.57 \cdot H C+43.7 \cdot L^{\text {beam }}
$$

where $H C$ is the holding capacity in cubic meters and $L^{\text {beam }}$ is the vessel beam length (width) in meters. The holding capacity was estimated by converting the gross tons to cubic meters ( 2.83 cubic meters per gross ton) (conversion factor information- $100 \mathrm{ft}^{3}$ per gross ton--obtained from www.themaritimesite.com/a-guide-to-understanding-ship-weight-and-tonnage-measurements/).

\section{S3. The mass of metals in the main engine}

We used a linear relationship between the rated engine power and the main engine weight to estimate the mass of the main engines of the fleet, $M^{M E}$ (in metric tons), using the following formula:

$$
M^{M E}=0.0061 \cdot P^{M E}+15.361
$$

where $P^{M E}$ is the rated engine power of the main engine (in $\mathrm{kW}$ ).

\section{S4. Anti-fouling paint for the hull}

We estimated the volume of anti-fouling substances, $V^{\text {af }}$ (in liters), using the following formula:

$$
V^{a f}=\sum_{j} A_{j}^{h u l l} \cdot V^{s, a f}
$$

where Ahull is the area of the hull, $V^{a f}$ is the specific volume of the anti-fouling substance (liters per square meter), and $j$ is the individual vessel in the fleet. For anti-fouling estimates, one liter of paint covers between $8.7-9.8 \mathrm{~m} 2$ of hull area (Jamestown Distributors of Interlux anti-fouling paint available 
at: www.jamestowndistributors.com/userportal/document.do?docId=331). We assumed that the vessels are painted every two years (Ziegler et al., 2015).

\section{S5. Area of the hull}

We estimated the area of the hull, $A^{\text {hull }}$ (in square meters), using the following formula (estimate from Jamestown Distributors of Interlux anti-fouling paint available at:

www.jamestowndistributors.com/userportal/document.do?docId=331):

$$
A^{\text {hull }}=0.85 \cdot L O A \cdot L^{\text {beam }}
$$

where $L O A$ is the length overall (in meters).

\section{S6. Volume of primer paint}

The volume of primer paint, $V^{\text {primer }}$ (in liters), of top-side paint required using a linear relationship based on the length of the vessel using the following equations (Interlux product distributor paint volume estimates available at: www.yachtpaint.com/usa/diy/ask-the-experts/how-much-topside-paint-do-ineed.aspx) :

$$
V_{i}^{\text {primer }}=0.653 \sum_{j}\left(L O A_{j}-2.082\right)
$$

\section{S7. Volume of polyurethane}

The volume of polyurethane paint, $V^{\text {polyurethane }}$ (in liters), of top-side paint required using a linear relationship based on the length of the vessel using the following equations (Interlux product distributor paint volume estimates available at: www.yachtpaint.com/usa/diy/ask-the-experts/how-much-topsidepaint-do-i-need.aspx) :

$$
V_{i}^{\text {polyurethane }}=0.963 \sum_{j}\left(L O A_{j}-3.028\right)
$$

\section{S8. Volume of enamel}

The volume of polyurethane paint, $V^{\text {enamel }}$ (in liters), of top-side paint required using a linear relationship based on the length of the vessel using the following equations (Interlux product distributor paint volume estimates available at: www.yachtpaint.com/usa/diy/ask-the-experts/how-much-topside-paint-do-ineed.aspx) :

$$
V_{i}^{\text {enamel }}=1.15 \sum_{j}\left(L O A_{j}-3.312\right)
$$




\section{S9. $\mathrm{SO}_{2}$ emissions}

We calculated the $\mathrm{SO}_{2}$ emissions, $E F^{e x h, S O 2}$ ( $\mathrm{g} \mathrm{SO}_{2} / \mathrm{kg}$ fuel), of the fishing fleet and the container ship using the following equation:

$$
E F_{j}^{e x h, S O_{2}}=f_{j}^{S} \cdot 2 \cdot f^{S O_{2}}
$$

where $f^{S}$ is the fuel sulfur fraction ( $\mathrm{g} \mathrm{S}$ per kg fuel), 2 is the ratio of molecular weights of $\mathrm{SO}_{2}$ to $\mathrm{S}, f^{5 O 2}$ is the fraction of fuel sulfur emitted as $\mathrm{SO}_{2}(97.8 \%)$, and $j$ is the fuel sulfur fraction (ICF International, 2009).

\section{S10. Organic carbon emissions}

We calculated the emission factor for $\mathrm{OC}, E F^{e x h, O C}$ ( $\mathrm{g} \mathrm{OC} / \mathrm{kg}$ fuel), using the following equation:

$$
E F_{k}^{e x h, O C}=E F_{k}^{e x h, B C} \cdot \frac{P O M}{1.2 \cdot B C}
$$

where $E F^{e x h, B C}$ is the emission factor of BC, $P O M$ is particulate organic matter which is $120 \%$ of the OC, the ratio of $P O M$ to $B C$ is 1.4 (Petzold et al., 2011; Fuglestvedt et al., 2010) and $k$ is the engine type. The engine type is either slow speed diesel (SSD), medium speed diesel (MSD), or high speed diesel (HSD). For our calculations we use a density of $825( \pm 0.7)$ and $840( \pm 7.3)$ grams per liter for ULSD and MGO, respectively.

\section{S11. Climate forcing normalized by the final product calculations}

We summed the climate forcing of emissions normalized by the final product, $N C F$ (in $\mathrm{kg} \mathrm{CO}_{2} \mathrm{e}$ per $\mathrm{kg}$ final product), with the following formula:

$$
N C F_{j, k, l}=\sum_{i} N C F_{j, k, l}^{i}
$$

where $i$ is the phase of the seafood supply-chain (fishing, primary processing, transport to secondary processing, secondary processing, transport to retail, and retail), $j$ is the climate forcing time horizon (20y or 100-y), $k$ is the retail market (Germany, Netherlands, Japan, South Korea, or United States), and $l$ is the finished product (Alaska pollock battered-and-breaded fillets or crab-flavored sticks).

\section{S12. Climate forcing normalized by the final product for fishing activities}

We normalized the climate forcing of fishing emissions by the final product, $N C F^{f}$ (in $\mathrm{kg} \mathrm{CO}_{2}$ e per $\mathrm{kg}$ final product), with the following formula: 


$$
N C F_{j, k, l}^{f}=\frac{C F_{j, k}^{f} \cdot \frac{M^{A F A_{-} c-p_{-} p o l}}{M^{A F A_{-} c-p_{-} t}} \cdot \frac{M_{m}^{a t-s e a \_i p}}{M^{a t-s e a \_t p}}}{r_{l}^{f p} \frac{M^{a t-s e a_{-} i p}}{M^{a t-s e a_{-} t p}} \cdot \frac{M^{A F A-c-p_{-} p o l}}{M^{a t-s e a \_p o l}}}
$$

where $C F^{f}$ is the net climate forcing associated with fishing activities, $M^{A F A_{-} c p_{-} p o l}$ (in $\mathrm{kg}$ ) is the mass of the live-weight catch of Alaska pollock by the AFA catcher-processer fleet, $M^{A F A_{-}{ }^{c-p}{ }_{-}{ }^{t}}$ (in $\left.\mathrm{kg}\right)$ is the mass of the total catch (including pollock and bycatch) of the AFA catcher-processer fleet, $M^{a t-s e a-i p}$ (in $\mathrm{kg}$ ) is the mass of the at-sea processor catch of the intermediary products, $M^{a t-s e a-t p}$ (in $\mathrm{kg}$ ) is the mass of all atsea Alaska pollock products, $r^{f p}$ is the ratio of final product to intermediate product, $M^{A F A-c-p \_i p}$ (in $\mathrm{kg}$ ) is the mass of the intermediate Alaska pollock product from the AFA catcher-processer fleet, and $M^{\text {at-sea } \text { pol }}$ is the mass of at-sea pollock catch and $\mathrm{m}$ is the intermediary product (fillet or surimi).

We estimated the net climate forcing as the product of the inventory items associated with fishing activities (Table 1, main manuscript), emission factors (Tables S16, S17, and S20) and GWPs (Tables S23 and S24). The means and standard deviations of the mass of the live-weight catch of Alaska pollock and the mass of the total catch by the AFA catcher-processer fleet are presented in Table 1 (main manuscript). The mean and standard deviation of the annual production (2012-2015) by at-sea processors of intermediary products (Table S6) is $9.23( \pm 0.89) \times 10^{7}$ and $8.56( \pm 0.80) \times 10^{7} \mathrm{~kg}$ for pollock fillets and surimi, respectively. The mean and standard deviation of the annual production (2012-2015) by at-sea processors of total pollock products (Table S6) is $2.77( \pm 0.15) \times 10^{8} \mathrm{~kg}$. The means and standard deviations of the mass of the intermediate Alaska pollock products (fillets and surimi) from the AFA catcher-processer fleet is presented in Table 2 (main manuscript). The ratios of the final product to the intermediate products are 1.80 (323.47 $\mathrm{g}$ frozen battered-and-breaded fillets to $180 \mathrm{~g}$ frozen fillet) as reported in Vázquez-Rowe et al. (2013) and 1.88 (Hur et al., 2011).

\section{S13. Climate forcing normalized by the final product for primary processing}

We normalized the climate forcing of primary processing emissions by the final product, $N C F^{p p}$ (in $\mathrm{kg}$ $\mathrm{CO}_{2}$ e per $\mathrm{kg}$ final product), with the following formula:

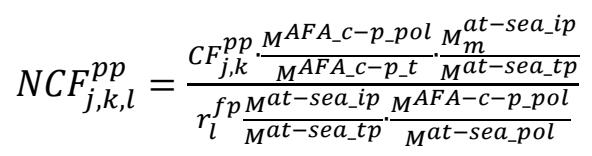

where $C F^{p p}$ is the net climate forcing associated with primary processing activities

We estimated the net climate forcing as the product of the inventory items associated with primary processing activities (Table 2), emission factors (Tables S16, S17, S20, and S21) and GWPS (Tables S23 and S24). 


\section{S14. Climate forcing normalized by the final product for transportation to secondary processors}

We normalized the climate forcing associated with transportation of products to the secondary processor by the final product, $N C F_{-}^{t s p}$ (in $\mathrm{kg} \mathrm{CO}_{2} \mathrm{e}$ per $\mathrm{kg}$ final product), with the following formula:

$$
N C F_{j, k, l}^{t \_s p}=\frac{C F_{j, k, l}^{t \leq s p}}{r_{l, m}^{f p} \cdot f_{m}^{a t-s e a \_i p} \cdot M_{k, m}^{p r o d \_d i s p} \cdot \frac{M^{A F A-c-p \_p o l}}{M^{\text {at-sea_pol }}}}
$$

where $C F^{t} s p$ is the net climate forcing associated with transportation of products to the secondary

processor, $f^{\text {at-sea_ip }}$ (in $\mathrm{kg}$ ) is the fraction of at-sea processor intermediary products, and $\mathrm{r}^{\mathrm{fp}}$ is the ratio of final product to intermediate product, and $M^{\text {prod_disp }}$ is the mass disposition of product to each country,

We estimated the net climate forcing as the product of the inventory items associated with transport to secondary processor (Table S12 and S13), emission factors (Tables S18, and S19) and GWPS (Tables S23 and S24).

\section{S15. Climate forcing normalized by the final product for secondary processing}

We normalized the climate forcing associated with secondary processing by the final product, $N C F^{s p}$ (in $\mathrm{kg} \mathrm{CO} 2 \mathrm{e}$ per kg final product), with the following formula:

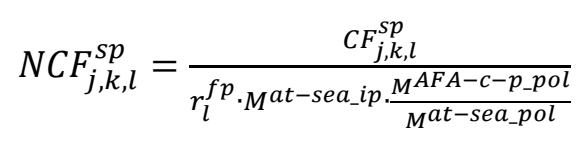

where $C F^{s p}$ is the net climate forcing associated with secondary processing.

We estimated the net climate forcing as the product of the inventory items associated with secondary processing activities (Tables 3 and 4, main manuscript), emission factors (Tables S20-S22) and GWPs (Table S23).

\section{S16. Climate forcing normalized by the final product for transportation to retailer} We normalized the climate forcing associated with transportation of products to the retailer by the final product, $N C F^{t} r$ (in $\mathrm{kg} \mathrm{CO}_{2} \mathrm{e}$ per $\mathrm{kg}$ final product), with the following formula:

$$
N C F_{j, k}^{t \_} r, l=\frac{C F_{j, k}^{t} r, l}{r_{l, m}^{f p} \cdot f_{m}^{a t-s e a \_i p} \cdot M_{k, m}^{p r o d \_d i s p} \cdot \frac{M^{A F A-c-p \_p o l}}{M^{a t-s e a \_p o l}}}
$$

where $C F^{t^{r}}$ is the net climate forcing associated with transportation to of products to the retailer. 
We estimated the net climate forcing as the product of the inventory items associated with transport to the retailer (Table S14 and S15), emission factors (Tables S18 and S19) and GWPs (Tables S23 and S24).

\section{S17. Climate forcing normalized by the final product for the retail market}

We normalized the climate forcing associated with retail activities by the final product, $N C F^{r}$ (in $\mathrm{kg} \mathrm{CO}_{2} \mathrm{e}$ per kg final product), with the following formula:

$$
N C F_{j, k, l}^{r}=\frac{C F_{j, k, l}^{r}}{r_{l}^{f p} \cdot M^{a t-s e a \_i p \cdot M^{A F A-c-p \_p o l}}}
$$

where $C F^{r}$ is the net climate forcing associated with retail activities.

We estimated the net climate forcing as the product of the inventory items associated with retail activities (Table 5, main manuscript), emission factors (Tables S20 and S21) and GWP (Table S23). 


\section{References}

Aamaas, B, Berntsen, TK, Fuglestvedt, JS, Shine, KP and Bellouin, N. 2015. Multimodel emission metrics for regional emissions of short lived climate forcers. Atmos Chem Phys Discuss 15(18): 2608926130 DOI: 10.5194/acpd-15-26089-2015.

Abella, JP and Bergerson, JA. 2012. Model to Investigate Energy and Greenhouse Gas Emissions Implications of Refining Petroleum: Impacts of Crude Quality and Refinery Configuration. Environ Sci Technol 46(24): 13037-13047 DOI: 10.1021/es3018682.

Blowers, P and Lownsbury, JM. 2010. Carbon dioxide emission implications if hydrofluorocarbons are regulated: a refrigeration case study. Environ Sci Technol 44(5): 1526 DOI: 10.1021/es9023354.

Bovea, M, Cabello, R and Querol, D. 2007. Comparative life cycle assessment of commonly used refrigerants in commercial refrigeration systems. Int J Life Cycle Assess 12(5): 299-307 DOI: 10.1065/lca2007.06.346.

Brandt, AR, Sun, Y and Vafi, K. 2015. Uncertainty in Regional-Average Petroleum GHG Intensities: Countering Information Gaps with Targeted Data Gathering. Environ Sci Technol 49(1): 679-686 DOI: 10.1021/es505376t.

Buffaloe, GM, Lack, DA, Williams, EJ, Coffman, D, Hayden, KL, Lerner, BM, Li, S-, Nuaaman, I, Massoli, P, Onasch, TB, Quinn, PK and Cappa, CD. 2014. Black carbon emissions from in-use ships: a California regional assessment. Atmos Chem Phys 14(4): 1881-1896 DOI: 10.5194/acp-14-1881-2014.

Cai, H and Wang, MQ. 2014. Estimation of Emission Factors of Particulate Black Carbon and Organic Carbon from Stationary Mobile, and Non-point Sources in the United States for Incorporation into GREET, report ANL/ESD-14/6. Argonne, IL: Argonne National Laboratories DOI: 10.2172/1155133.

Cappa, CD, Williams, EJ, Lack, DA, Buffaloe, GM, Coffman, D, Hayden, KL, Herndon, SC, Lerner, BM, Li, S-, Massoli, P, McLaren, R, Nuaaman, I, Onasch, TB and Quinn, PK. 2014. A case study into the measurement of ship emissions from plume intercepts of the NOAA ship Miller Freeman. Atmos Chem Phys 14(3): 1337-1352 DOI: 10.5194/acp-14-1337-2014.

Cascini, A, Gamberi, M, Mora, C, Rosano, M and Bortolini, M. 2016. Comparative Carbon Footprint Assessment of commercial walk-in refrigeration systems under different use configurations. $J$ Clean Prod 112: 3998-4011 DOI: 10.1016/j.jclepro.2015.08.075.

Clark, D, Kozlova, V and Schaur, G. 2014. Supply chain uncertainty in ocean transit as a trade barrier. In: Proceedings, working paper, Department of Economics, University of Tennessee. Available at http://economics.ucdavis.edu/events/departmentseminars/papers/Schaur123.pdf.

Collins, WJ, Sitch, S and Boucher, O. 2010. How vegetation impacts affect climate metrics for ozone precursors. J Geophys Res 115(D23) DOI: 10.1029/2010JD014187.

Corbett, JJ and Koehler, HW. 2003. Updated emissions from ocean shipping. J Geophys Res Atmos 108(D20): 4650 DOI: 10.1029/2003JD003751.

Corbett, JJ, Deans, E, Silberman, J, Morehouse, E, Craft, E and Norsworthy, M. 2012. Panama Canal expansion: emission changes from possible US west coast modal shift. Carbon Manag 3(6): 569-588 DOI: $10.4155 / \mathrm{cmt} .12 .65$.

COWI, E3-M Lab and Exergia. 2014. Study on actual GHG data for diesel, petrol, kerosene and natural gas. Brussels: European Commission, DG Ener. 
Duffy, J. 2015. Staff Report: Calculating Carbon Intensity Values of Crude Oil Supplied to California Refineries. Sacramento, California: California Environmental Protection Agency Air Resources Board. Available at https://www.arb.ca.gov/fuels/lcfs/peerreview/050515staffreport_opgee.pdf.

Endresen, Ø, Sørgård, E, Behrens, HL, Brett, PO and Isaksen, ISA. 2007. A historical reconstruction of ships' fuel consumption and emissions. J Geophys Res Atmos 112(D12): D12301 DOI:

10.1029/2006JD007630.

Endresen, Ø, Sørgård, E, Sundet, JK, Dalsøren, SB, Isaksen, ISA, Berglen, TF and Gravir, G. 2003. Emission from international sea transportation and environmental impact. J Geophys Res Atmos 108(D17) DOI: $10.1029 / 2002 J D 002898$.

Eyjólfsdóttir, H, Jónsdóttir, H, Yngvadóttir, E and Skuladóttir, B. 2003. Environmental effects of fish on the consumer dish - life cycle assessment of Icelandic frozen cod products, Skýrsla ITÍ/ IceTec report 0305/HTD05. Reykjavík, Iceland: Icelandic Fisheries Laboratories / IceTec, Technical Institute of Iceland. Available at http://www.matis.is/media/utgafa/Verkefnaskyrsla0603.pdf.

Eyring, V, Stevenson, DS, Lauer, A, Dentener, FJ, Butler, T, Collins, WJ, Ellingsen, K, Gauss, M, Hauglustaine, DA, Isaksen, ISA, Lawrence, MG, Richter, A, Rodriguez, JM, Sanderson, M, Strahan, SE, Sudo, K, Szopa, S, van Noije, T. P. C. and Wild, O. 2007. Multi-model simulations of the impact of international shipping on Atmospheric Chemistry and Climate in 2000 and 2030. Atmos Chem Phys 7(3): 757-780 DOI: 10.5194/acp-7-757-2007.

Fissel, B, Dalton, M, Felthoven, R, Garber-Yonts, B, Haynie, A, Kasperski, S, Lee, J, Lew, D, Santos, A, Seung, C and Sparks, K. 2016. Stock assessment and fishery evaluation report for the groundfish fisheries of the Gulf of Alaska and Bering Sea/Aleutian Islands area: Economic status of the groundfish fisheries off Alaska, 2015. Anchorage, Alaska: North Pacific Fisheries Management Council. Available at https://www.afsc.noaa.gov/REFM/Docs/2016/economic.pdf.

Fitzgerald, WB, Howitt, OJA, Smith, IJ and Hume, A. 2011. Energy use of integral refrigerated containers in maritime transportation. Energy Policy 39(4): 1885-1896 DOI:

10.1016/j.enpol.2010.12.015.

Freight Filter. 2013. Full Container Load (FCL) Guide. Maldon, Essex, UK: Freight Filter, Ltd.http://freightfilter.com/full-container-load-fcl-guide/.

Fréon, P, Avadí, A, Vinatea Chavez, R and Iriarte Ahón, F. 2014. Life cycle assessment of the Peruvian industrial anchoveta fleet: boundary setting in life cycle inventory analyses of complex and plural means of production. Int J Life Cycle Assess 19(5): 1068-1086 DOI: 10.1007/s11367-014-0716-3.

Fuglestvedt, Berntsen, T, Myhre, G, Rypdal, K and Skeie, RB. 2008. Climate forcing from the transport sectors. Proc Natl Acad Sci USA 105(2): 454-458 DOI: 10.1073/pnas.0702958104.

Fuglestvedt, Shine, KP, Berntsen, T, Cook, J, Lee, DS, Stenke, A, Skeie, RB, Velders, GJM and Waitz, IA. 2010. Transport impacts on atmosphere and climate: Metrics. Atmos Environ 44(37): 4648-4677 DOI: 10.1016/j.atmosenv.2009.04.044.

Fulton, S. 2010. Fish and Fuel: Life cycle greenhouse gas emissions associated with Icelandic cod, Alaskan pollock, and Alaskan pink salmon fillets delivered to the United Kingdom [M.S. Thesis]. Halifax, Nova Scotia: Dalhousie University, Environmental Studies. Available at https://dalspace.library.dal.ca/xmlui/handle/10222/13042. Accessed June 10, 2017. 
Graham, J. 1984. Food and Agriculture Organization Fisheries Circular No. 771: Planning and engineering data, Fish freezing, Storage and equipment. Rome, Italy: Food and Agriculture Organization. Available at http://www.fao.org/docrep/003/r1076e/R1076E05.htm.

Greenway Products and Services, LLC. 2018. North American pallet weight: product specifications. New Brunswick, New Jersey, US: Greenway Products and Services, LLC.https://greenwaypsllc.com/palletweight/.

Headlands, R. K. et al. 2018. Transits of the Northwest Passage to the end of the 2018 navigation season. Cambridge, UK: Scott Polar Research Institute, University of Cambridge. Available at https://www.spri.cam.ac.uk/resources/infosheets/northwestpassage.pdf.

Hoang, HM, Brown, T, Indergard, E, Leducq, D and Alvarez, G. 2016. Life cycle assessment of salmon cold chains: comparison between chilling and superchilling technologies. J Clean Prod 126: 363-372 DOI: 10.1016/j.jclepro.2016.03.049.

Hur, SJ, Choi, YJ, Choi, BD, Kim, BG and Jin, SK. 2011. Quality characteristics of imitation crab sticks made from Alaska Pollack and spent laying hen meat. LWT - Food Science and Technology 44(6): 14821489 DOI: 10.1016/j.lwt.2011.02.013.

ICF International. 2009. Current methodologies in preparing mobile source port-related emissions inventories: Final report prepared for the US EPA. Washington D.C.: US Environmental Protection Agency. Available at http://epa.gov/cleandiesel/documents/ports-emission-inv-april09.pdf.

IHS Markit Global. 2017. Sea-web ships [database]. London, England, UK: IHS Markit Global. Available at https://maritime.ihs.com/\#.

International Energy Agency. 2017. The Future of Trucks Implications for energy and the environment. Paris, France: International Energy Agency. Available at https://webstore.iea.org/the-future-of-trucks.

Lack, D, Lerner, B, Granier, C, Baynard, T, Lovejoy, E, Massoli, P, Ravishankara, AR and Williams, E. 2008. Light absorbing carbon emissions from commercial shipping. Geophys Res Lett 35(13) DOI: 10.1029/2008GL033906.

Laso, J, Vázquez-Rowe, I, Margallo, M, Crujeiras, R, Irabien, A and Aldaco, R. 2018. Life cycle assessment of European anchovy (Engraulis encrasicolus) landed by purse seine vessels in northern Spain. Int J Life Cycle Assess 23(5): 1107-1125 DOI: 10.1007/s11367-017-1318-7.

Lauer, A, Eyring, V, Hendricks, J, Joeckel, P and Lohmann, U. 2007. Global model simulations of the impact of ocean-going ships on aerosols, clouds, and the radiation budget. Atmos Chem Phys 7(19): 5061 5079 DOI: $10.5194 / \mathrm{acp}-7-5061-2007$.

Marine Traffic. 2018. Voyage planner [database]. London, England, UK: Marine Traffic.www.marinetraffic.com/en/voyage-planner.

Moreno-Gutiérrez, J, Calderay, F, Saborido, N, Boile, M, Valero, RR and Durán-Grados, V. 2015. Methodologies for estimating shipping emissions and energy consumption: A comparative analysis of current methods. Energy 86: 603-616 DOI: 10.1016/j.energy.2015.04.083.

Moreno-Gutiérrez, J, Durán-Grados, V, Uriondo, Z and Ángel Llamas, J. 2012. Emission-factor uncertainties in maritime transport in the Strait of Gibraltar, Spain. Atmos Meas Tech Discuss 5(4): 59535991 DOI: 10.5194/amtd-5-5953-2012. 
Myhre, G, Shindell, D, Breon, F-M, Collins, W, Fuglestvedt, J, Huang, J, Koch, D, Lamarque, JF, Lee, D, Mendoza, B, Nakajima, T, Robock, A, Stephens, G, Takemura, T and Zhang, H 2013, Anthropogenic and Natural Radiative Forcing in eds. Stocker, TF, Quin, D, Plattner, G-K, et al. Climate Change 2013: The Physical Science Basis. Contribution of Working Group I to the Fifth Assessment Report of the Intergovernmental Panel on Climate Change. Cambridge, UK and New York, US: Cambridge University Press: 659-740.

Narayanaswamy, V, Scott, JA, Ness, JN and Lochhead, M. 2003. Resource flow and product chain analysis as practical tools to promote cleaner production initiatives. J Clean Prod 11(4): 375-387 DOI: $10.1016 /$ S0959-6526(02)00059-8.

National Marine Fisheries Service. 2016. Exports of fishery products [database]. Washington D.C, US: NOAA / US Department of Commerce. Available at www.st.nmfs.noaa.gov/commercialfisheries/foreign-trade/index.

North Pacific Fishery Management Council. 2016. Pollock Conservation Cooperative and High Seas Catchers' Cooperative Joint Annual Report 2015. Anchorage, Alaska, US: North Pacific Fishery Management Council. Available at https://alaskafisheries.noaa.gov/sites/default/files/reports/pcchscc2015.pdf.

North Pacific Fishery Management Council. 2015. Pollock Conservation Cooperative and High Seas Catchers Cooperative Joint Annual Report 2014. Anchorage, Alaska, US: North Pacific Fishery Management Council. Available at Pollock Conservation Cooperative and High Seas Catchers Cooperative Joint Annual Report 2014. Available at https://alaskafisheries.noaa.gov/sites/default/files/reports/pcchscc2014.pdf.

North Pacific Fishery Management Council. 2014. Pollock Conservation Cooperative and High Seas Catchers' Cooperative Final Joint Annual Report 2013. Anchorage, Alaska, US: North Pacific Fishery Management Council. Available at https://alaskafisheries.noaa.gov/sites/default/files/reports/pcchscc2013.pdf.

North Pacific Fishery Management Council. 2013. Pollock Conservation Cooperative and High Seas Catchers' Cooperative Final Joint Annual Report 2012. Anchorage, Alaska, US: North Pacific Fishery Management Council. Available at https://alaskafisheries.noaa.gov/sites/default/files/reports/pcchscc2012.pdf.

Olmer, N, Comer, B, Roy, B, Mao, X and Rutherford, D. 2017. Greenhouse gas emissions from global shipping, 2013-2015. Washington D.C., US: International Council on Clean Transportation. Available at https://www.theicct.org/sites/default/files/publications/Global-shipping-GHG-emissions-20132015 ICCT-Report_17102017_vF.pdf.

Park, M and Hahn, J. 2015. Regional Freight Demand Estimation Using Korean Commodity Flow Survey Data. Transp Res Proc 11: 504-514 DOI: 10.1016/j.trpro.2015.12.042.

Parker, RWR and Tyedmers, PH. 2012. Life Cycle Environmental Impacts of Three Products Derived from Wild-Caught Antarctic Krill (Euphausia superba). Environ Sci Technol 46(9): 4958-4965 DOI: 10.1021/es2040703.

Peter Pan Seafoods, I. 2016. Alaska pollock fillets: product specifications. Seattle, Washington, US: Peter Pan Seafoods, Inc. Available at https:/www.ppsf.com/ecom img/original-7-16-ss pollock.pdf. 
Petzold, A, Lauer, P, Fritsche, U, Hasselbach, J, Lichtenstern, M, Schlager, H and Fleischer, F. 2011. Operation of Marine Diesel Engines on Biogenic Fuels: Modification of Emissions and Resulting Climate Effects. Environ Sci Technol 45(24): 10394-10400 DOI: 10.1021/es2021439.

Pretty, JN, Ball, AS, Lang, T and Morison, JIL. 2005. Farm costs and food miles: An assessment of the full cost of the UK weekly food basket. Food Policy 30(1): 1-19 DOI: 10.1016/j.foodpol.2005.02.001.

Rodrigue, J., Comtois, C.and Slack, B. 2013, The Geography of Transport Systems, Third edition, Routledge Ltd - M.U.A, London.

Roy, P, Nei, D, Okadome, H, Nakamura, N, Orikasa, T and Shiina, T. 2008. Life cycle inventory analysis of fresh tomato distribution systems in Japan considering the quality aspect. J Food Eng 86(2): 225-233 DOI: 10.1016/j.jfoodeng.2007.09.033.

Sanchez-Rodrigues, V., Potter, A., Ahsan Naim, M., McKinnon, A. and Darby, J. 2010. "Measuring the Time and Distance Impact of Transport Uncertainty: a FCMG Case Study", Proceedings in Logistics Research Network Annual Conference 2010, Harrogate, UK, September 8-10, 2010. Wales, UK: Cardiff University.

Schau, EM, Ellingsen, H, Endal, A and Aanondsen, SA. 2009. Energy consumption in the Norwegian fisheries. J Clean Prod 17(3): 325-334 DOI: 10.1016/j.jclepro.2008.08.015.

Schmidt, JH. 2015. Life cycle assessment of five vegetable oils. J Clean Prod 87: 130-138 DOI: 10.1016/j.jclepro.2014.10.011.

Schøyen, H and Bråthen, S. 2011. The Northern Sea Route versus the Suez Canal: cases from bulk shipping. J Transp Geogr 19(4): 977-983 DOI: 10.1016/j.jtrangeo.2011.03.003.

Smith, T, Jalkanen, JP, Anderson, BA, Corbett, JJ, Faber, J, Hanayama, S, O'Keeffe, E, Parker, S, Johansson, L, Aldous, L, Raucci, C, Traut, M, Ettinger, S, Nelissen, D, Lee, DS, Ng, S, Agrawal, A, Winebrake, JJ, Hoen, M, Chesworth, S and Pandey, A. 2014. Third International Maritime Organization (IMO) GHG Study 2014. London: International Maritime Organization. Available at http://www.imo.org/OurWork/Environment/PollutionPrevention/AirPollution/Documents/GHG3\%20FU LL\%20REPORT.pdf.

State of Alaska. 2017. Commercial Fisheries Entries Commission Public Search [database]. Juneau, Alaska, US: State of Alaska. Available at https://www.cfec.state.ak.us/plook/\#vessels.

Sund, V. 2009. Environmental assessment of northeast arctic cod caught by long-lines and Alaska pollock caught by pelagic trawls, SIK Report No 799. Gothenburg, Sweden: SIK - The Swedish Institute for Food and Biotechnology. Available at: http://urn.kb.se/resolve?urn=urn:nbn:se:ri:diva-529.

Svanes, E, Vold, M and Hanssen, O. 2011. Environmental assessment of cod (Gadus morhua) from autoline fisheries. Int J Life Cycle Assess 16(7): 611-624 DOI: 10.1007/s11367-011-0298-2.

Tassou, SA, De-Lille, G and Ge, YT. 2009. Food transport refrigeration: Approaches to reduce energy consumption and environmental impacts of road transport. Appl Therm Eng 29(8): 1467-1477 DOI: 10.1016/j.applthermaleng.2008.06.027.

Tassou, SA, Ge, Y, Hadawey, A and Marriott, D. 2011. Energy consumption and conservation in food retailing. Appl Therm Eng 31(2): 147-156 DOI: 10.1016/j.applthermaleng.2010.08.023.

Tyedmers, P. 2000. Salmon and sustainability: the biophysical cost of producing salmon through the commercial salmon fishery and the intensive salmon culture industry [Dissertation]. University of British 
Columbia, Resource Managment and Environmental Studies. Available at http://hdl.handle.net/2429/13201. Accessed June 10, 2017.

United Nations Conference on Trade and Development. 2018. Review of Maritime Transport, 2017. Geneva, Switzerland: United Nations. Available at https://unctad.org/en/PublicationsLibrary/rmt2018_en.pdf.

US Census Bureau. 2013. Commodity Flow Public Use Microdata [dataset]\&nbsp; Washington D.C., US: US Department of Commerce. Available at https://www.census.gov/data/datasets/2012/econ/cfs/2012pums-files.html.

Van Passel, S. 2013. Food miles to assess sustainability: A revision. Sustainable Development 21(1): 1-17 DOI: $10.1002 / \mathrm{sd} .485$.

Vázquez-Rowe, I, Villanueva-Rey, P, Mallo, J, De la Cerda, Juan José, Moreira, MT and Feijoo, G. 2013. Carbon footprint of a multi-ingredient seafood product from a business-to-business perspective. $J$ Clean Prod 44: 200-210 DOI: 10.1016/j.jclepro.2012.11.049.

Wang, M. 2011. The Greenhouse Gases, Regulated Emissions, and Energy Use in Transportation (GREET) Model Software: GREET 1. Argonne, Illinois, US: Argonne National Laboratories. Available at: https://greet.es.anl.gov/index.php.

Wärtsilä Corporation. 2016. Wärtsilä 32: technical specification. Helsinki, Finland: Wärtsilä Corporation. Available at https://cdn.wartsila.com/docs/default-source/product-files/engines/ms-engine/brochure-o-ew32.pdf.

Winther, U, Ziegler, F, Hognes, ES, Emanuelsson, A, Sund, V and Ellingsen, H. 2009. Carbon footprint and energy use of Norwegian seafood products. Trondheim, Norway: SINTEF Fisheries and Aquaculture. Available at: https://www.sintef.no/globalassets/upload/fiskeri_og havbruk/fiskeriteknologi/filer-fra-erikskontorp-hognes/carbon-footprint-and-energy-use-of-norwegian-seafood-products---final-report--04_12_09.pdf.

Yau, PS, Lee, S and Ho, KF. 2012. Speed Profiles for Improvement of Maritime Emission Estimation. Environ Eng Sci 29(12): 176-1084 DOI: 10.1089/ees.2011.0399.

Ziegler, F, Groen, EA, Hornborg, S, Bokkers, EAM, Karlsen, KM and de Boer, I. 2015. Assessing broad life cycle impacts of daily onboard decision-making, annual strategic planning, and fisheries management in a northeast Atlantic trawl fishery. Int J Life Cycle Assess DOI: 10.1007/s11367-015-0898-3.

Ziegler, F, Winther, U, Hognes, ES, Emanuelsson, A, Sund, V and Ellingsen, H. 2013. The Carbon Footprint of Norwegian Seafood Products on the Global Seafood Market. J Ind Ecol 17(1): 103-116 DOI: 10.1111/j.1530-9290.2012.00485.x. 
Figures (S1-S14)

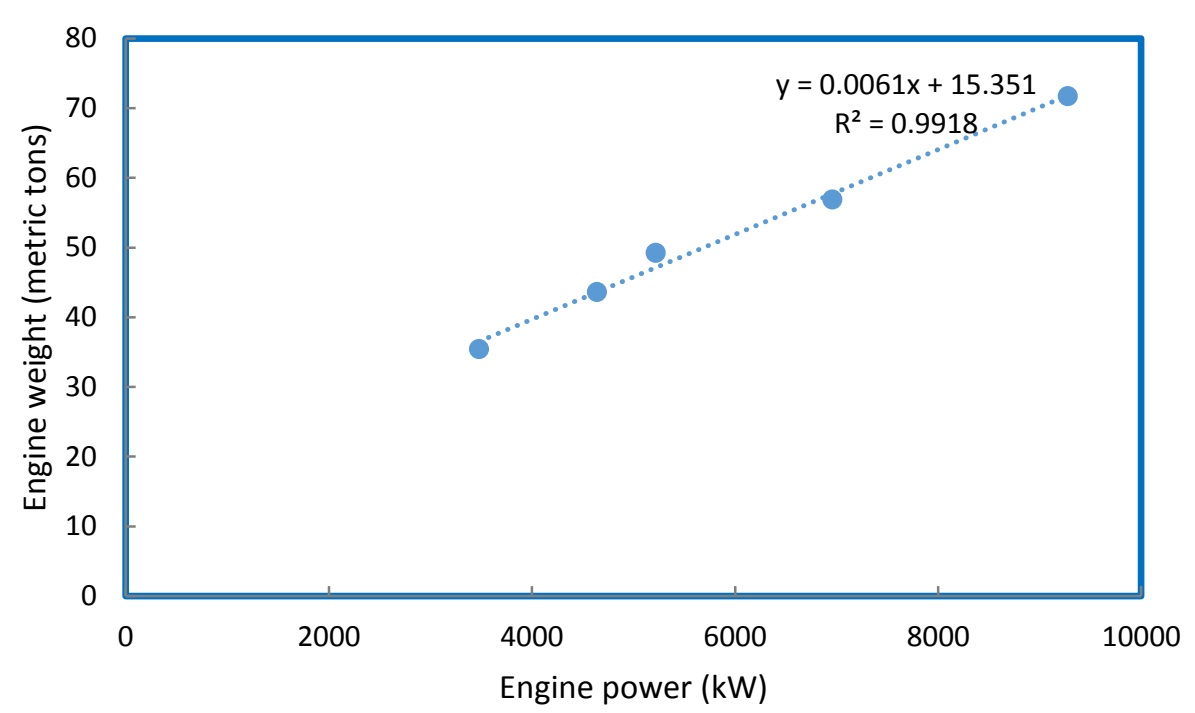

Figure S1. Linear relationship between engine weight and rated power.

Wärtsilä 32 engines weight (in metric tons) and power (in kW), linear equation, and the coefficient of determination $\left(\mathrm{R}^{2}\right)$. 


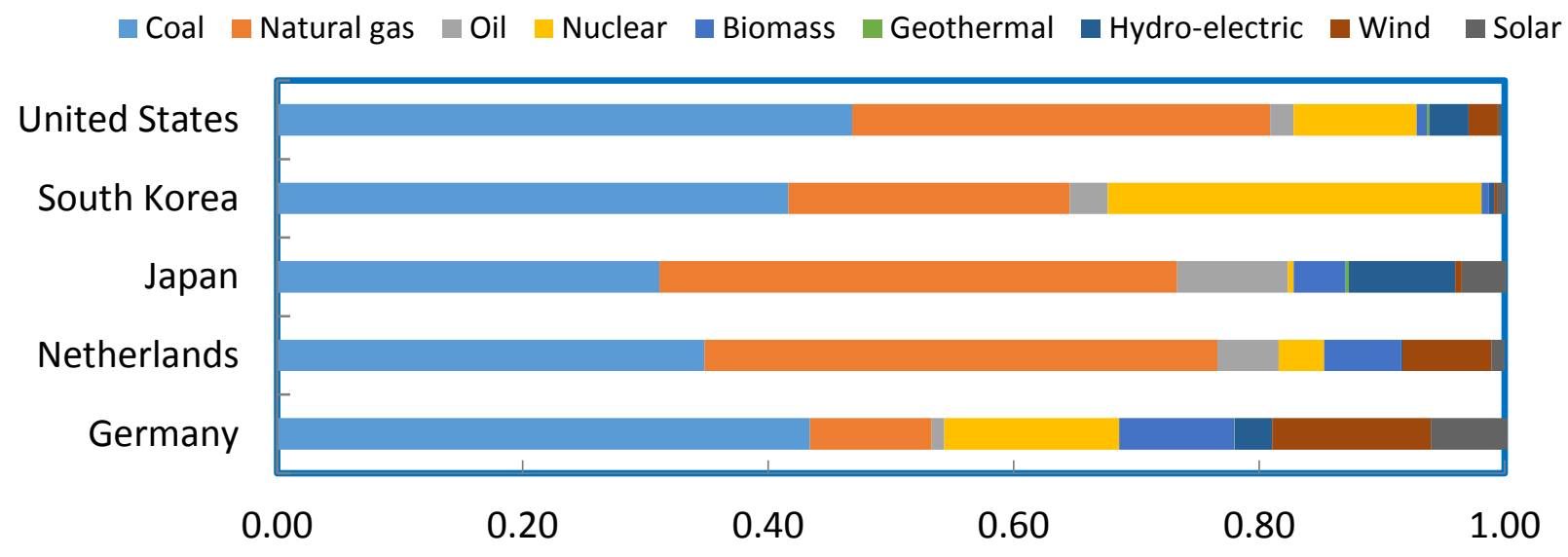

Figure S2. Energy mix for electricity of each market considered in this study. 


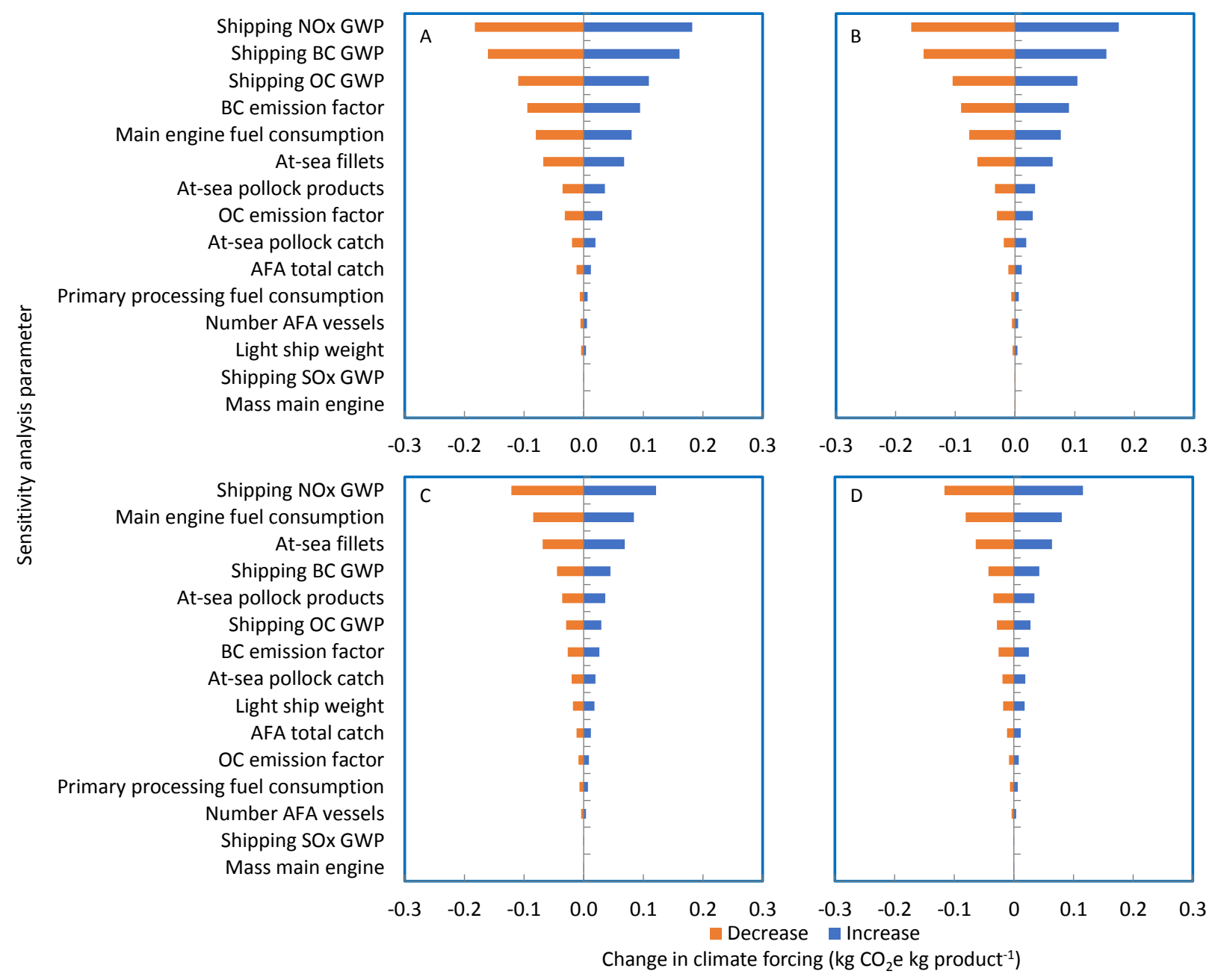

Figure S3. Sensitivity analysis of standard deviation parameters of the fishing phase of the seafood supply-chain.

Standard deviation parameters include shipping nitrogen oxide (NOx) global warming potential (GWP), shipping black carbon (BC) GWP, shipping organic carbon (OC) GWP, BC emission factor, main engine fuel consumption, at-sea pollock products, OC EF, at-sea pollock catch, American Fisheries Act (AFA) total catch, fraction (f) fuel to primary processing, number AFA vessels, light ship weight, mass main engine, and shipping sulfur oxide (SOx) GWP.Top panel (A, B): 20-y time horizon. Bottom panel (C, D): 100-y time horizon. Left panel (A, C): Battered-and-breaded fillets. Right panel: (B, D): Crab-flavored sticks. 


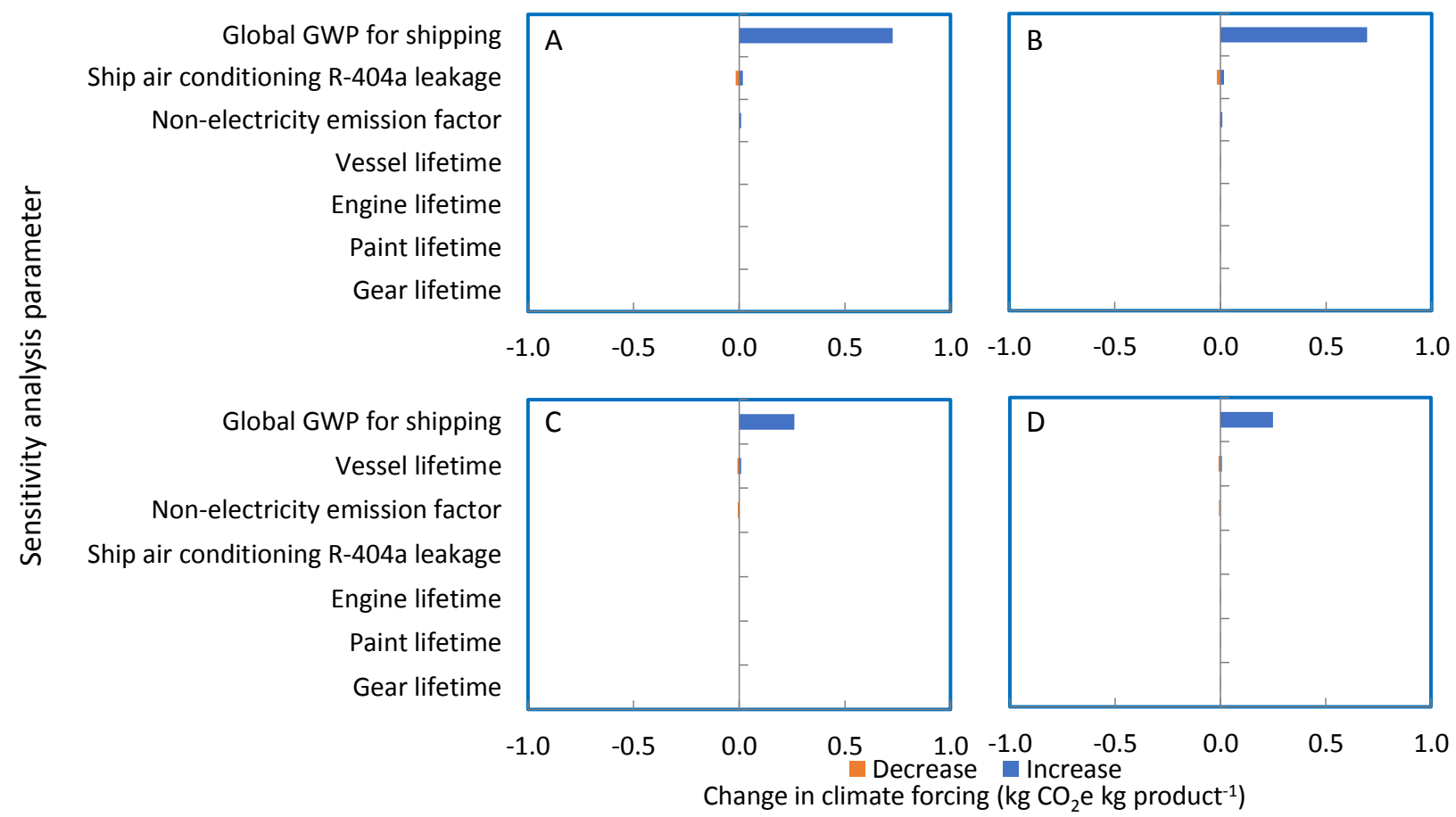

Figure S4. Sensitivity analysis of highly uncertain parameters for the fishing phase of the seafood supply-chain.

Top panel (A, B): 20-y time horizon. Bottom panel (C, D): 100-y time horizon. Left panel (A, C): Battered-and-breaded fillets. Right panel: (B, D): Crab-flavored sticks. 


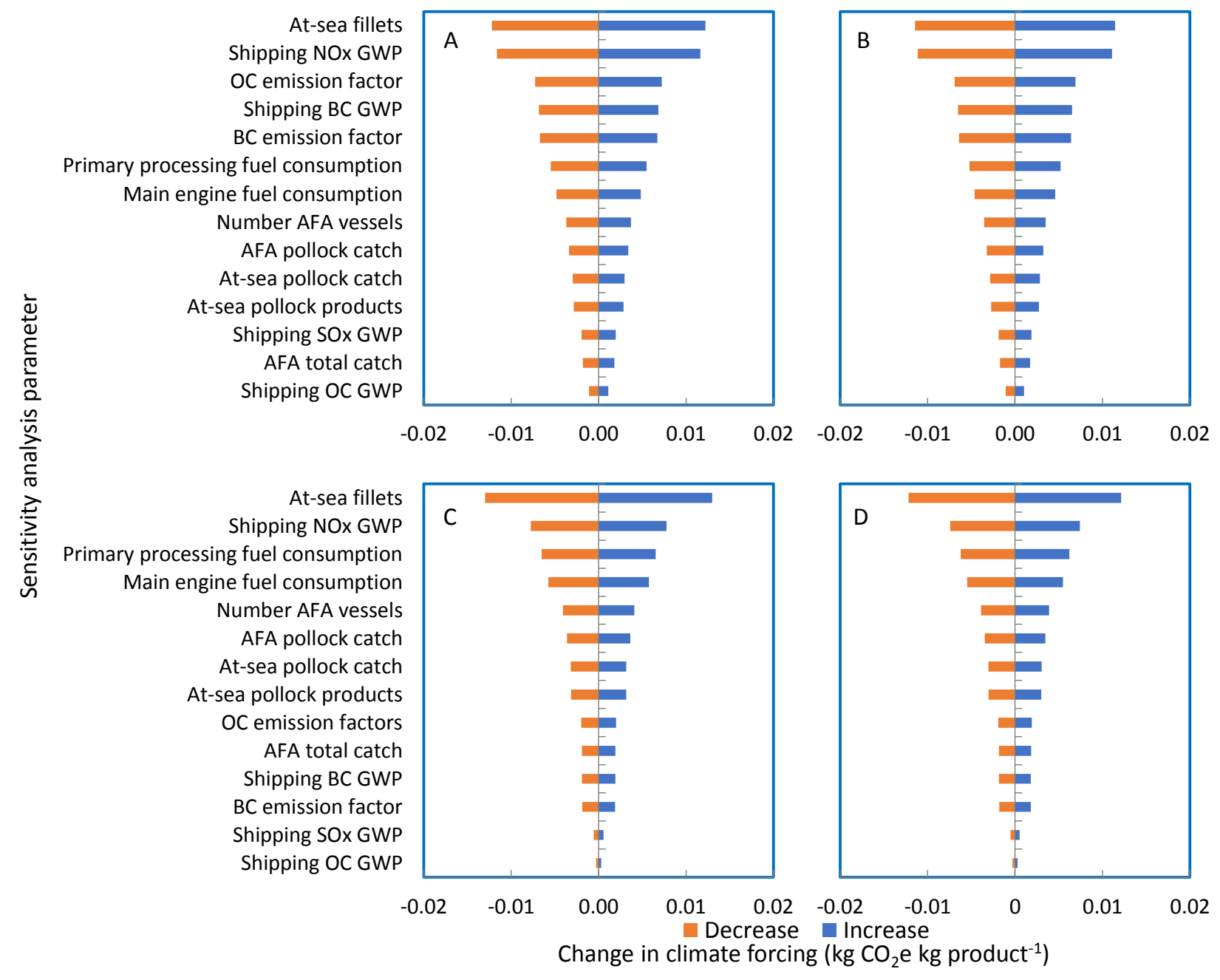

Figure S5. Sensitivity analysis of standard deviation parameters for the primary processing phase of the seafood supply-chain.

Standard deviation parameters which include shipping nitrogen oxide (NOx) global warming potential (GWP), shipping organic carbon (OC) GWP, shipping black carbon (BC) GWP, BC emission factor, fraction (f) fuel to primary processing, main engine fuel consumption, number American Fisheries Act (AFA) vessels, at-sea pollock catch, at-sea pollock products, shipping sulfur dioxide $\left(\mathrm{SO}_{2}\right) \mathrm{GWP}, \mathrm{AFA}$ total catch, at-sea fillets or at-sea surimi, and shipping OC GWP. Top panel (A, B): 20-y time horizon. Bottom panel (C, D): 100-y time horizon. Left panel (A, C): Battered-and-breaded fillets. Right panel: (B, D): Crab-flavored sticks. 


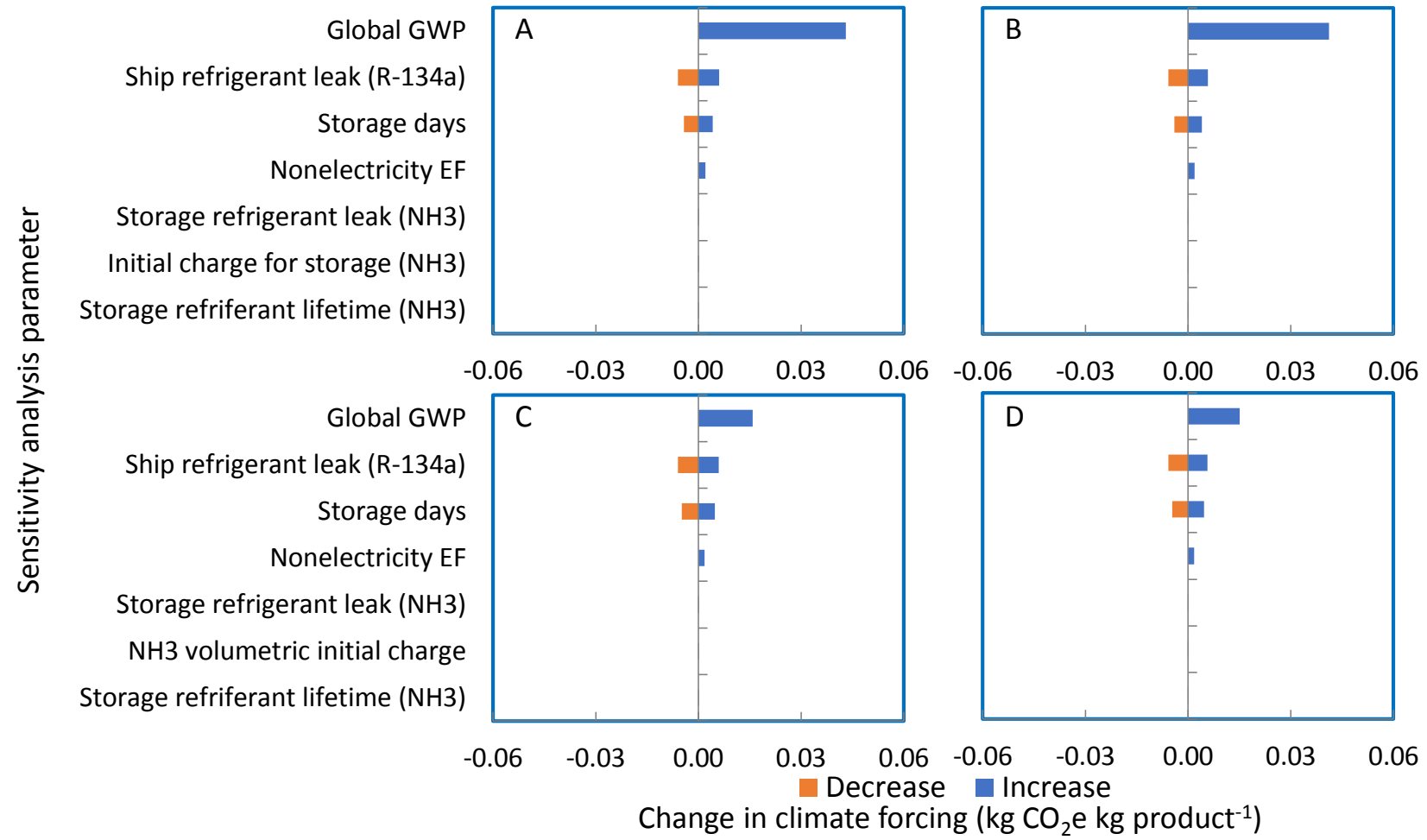

Figure S6. Sensitivity analysis of highly uncertain parameters of the primary processing phase of the seafood supply-chain.

Top panel (A, B): 20-y time horizon. Bottom panel (C, D): 100-y time horizon. Left panel (A, C): Battered-and-breaded fillets. Right panel: (B, D): Crab-flavored sticks. 


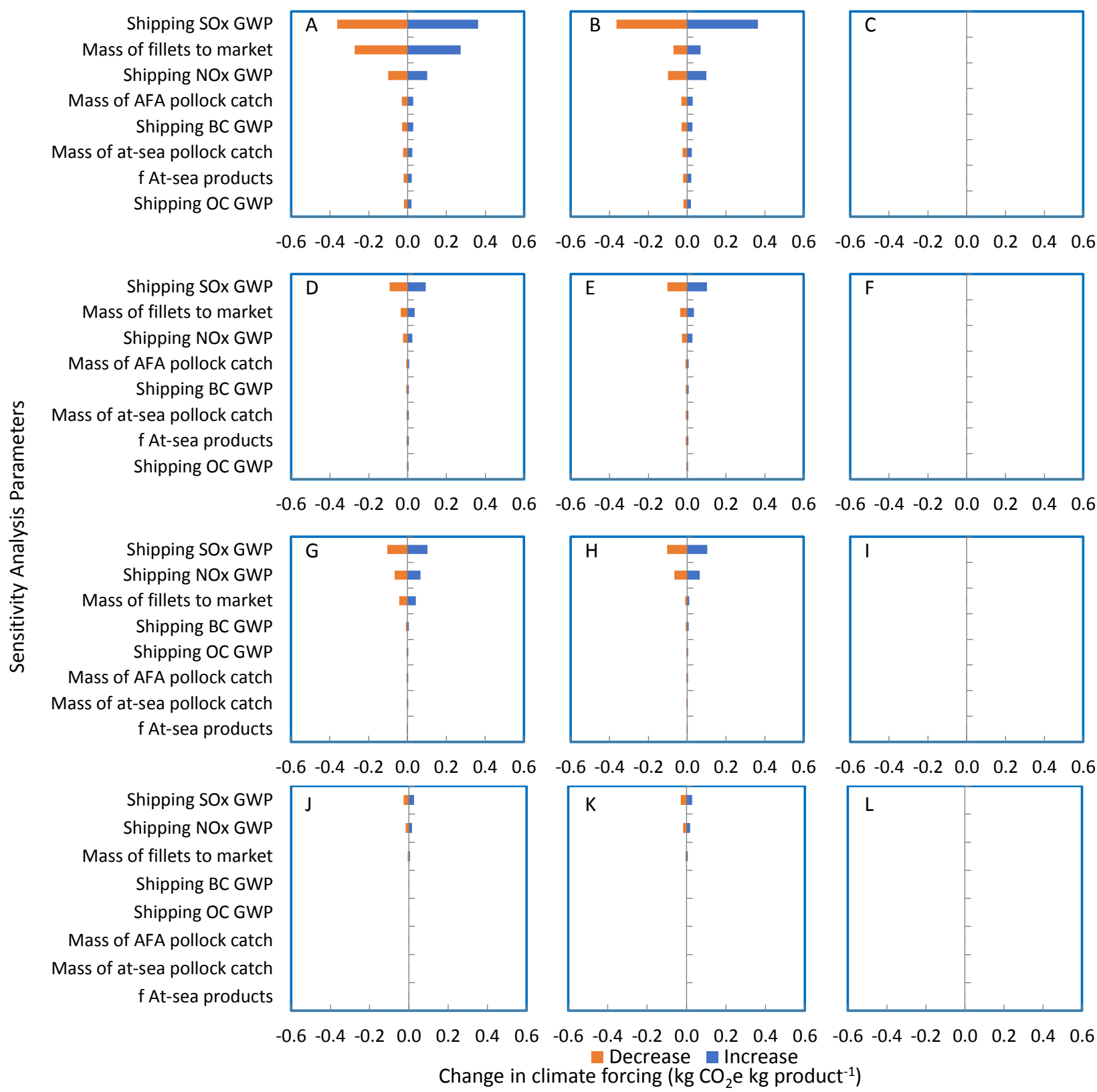

Figure S7. Sensitivity analysis of standard deviation parameters of transportation to secondary processors.

First (A, B, C) and third (G, H, I) rows: battered-and-breaded fillets. Panels (A, G): German market. Panels (B, H): Netherlands market. Panels (C, I): domestic market. Second (D, E, F) and fourth (J, K, L) rows: crab-flavored sticks. Panels (D, J): Japanese market. Panels (E, K): South Korean market. Panels 
(F, L): domestic market. First (A, B, C) and second (D, E, F) rows: 20-y time horizon. Third (G, H, I) and fourth (J, K, L) rows: 100-y time horizon.

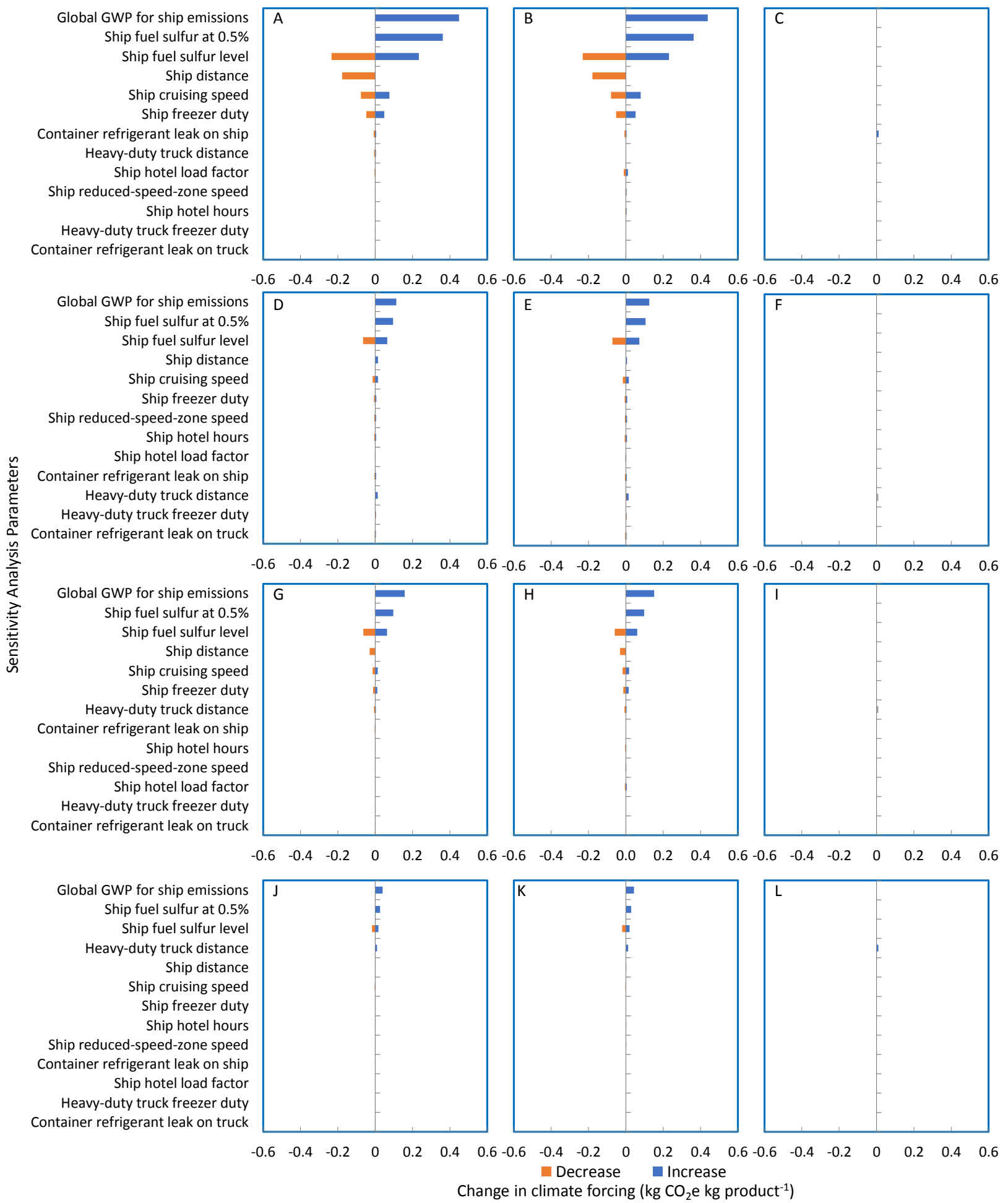


Figure S8. Sensitivity analysis of highly uncertain parameters of transportation to secondary processors.

First (A, B, C) and third (G, H, I) rows: battered-and-breaded fillets. Panels (A, G): German market. Panels (B, H): Netherlands market. Panels (C, I): domestic market. Second (D, E, F) and fourth (J, K, L) rows: crab-flavored sticks. Panels (D, J): Japanese market. Panels (E, K): South Korean market. Panels $(\mathrm{F}, \mathrm{L})$ : domestic market. First (A, B, C) and second (D, E, F) rows: 20-y time horizon. Third (G, H, I) and fourth (J, K, L) rows: 100-y time horizon. 


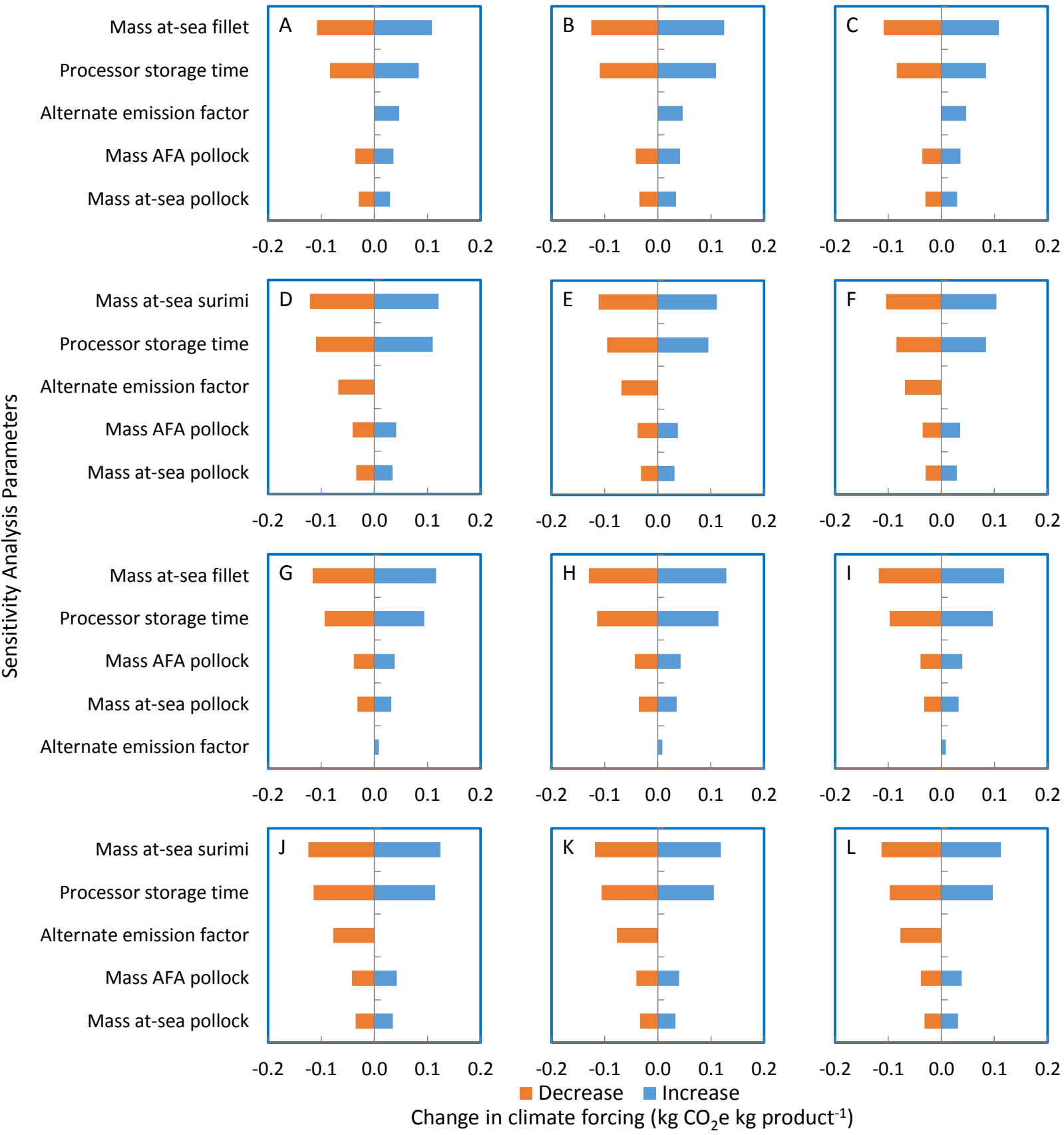

Figure S9. Sensitivity analysis of standard deviation and highly uncertain parameters of secondary processing.

The variables included in the standard deviation include the mass of at-sea pollock and the mass of pollock caught by the American Fisheries Act (AFA) fleet. The highly uncertain variables include processor storage time, and alternate emission factors. First (A, B, C) and third $(G, H, I)$ rows: battered- 
and-breaded fillets. Panels (A, G): German market. Panels (B, H): Netherlands market. Panels (C, I): domestic market. Second (D, E, F) and fourth (J, K, L) rows: crab-flavored sticks. Panels (D, J): Japanese market. Panels (E, K): South Korean market. Panels (F, L): domestic market. First (A, B, C) and second (D, E, F) rows: 20-y time horizon. Third $(\mathrm{G}, \mathrm{H}, \mathrm{I})$ and fourth $(\mathrm{J}, \mathrm{K}, \mathrm{L})$ rows: 100 -y time horizon. 


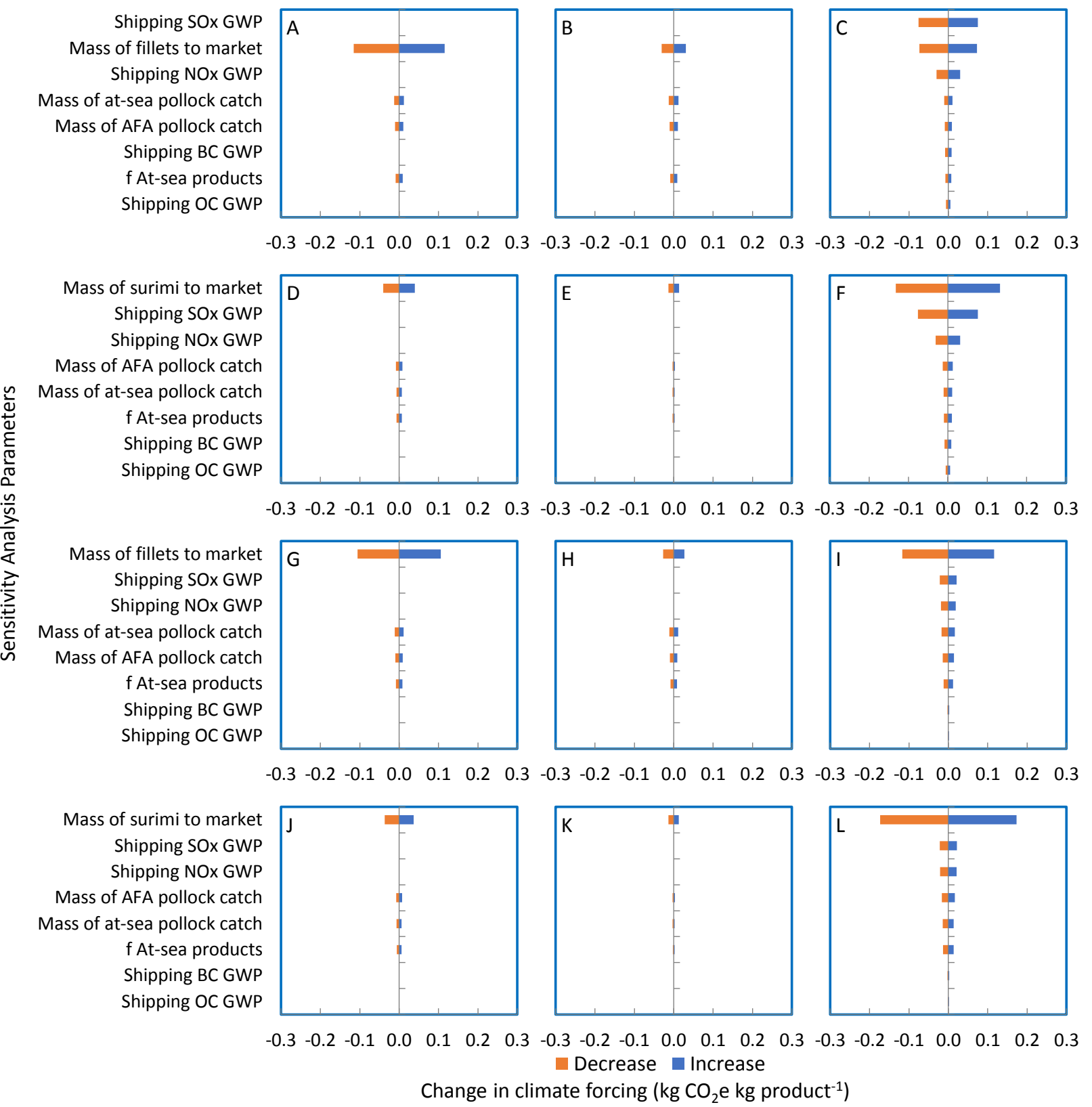

Figure S10. Sensitivity analysis of standard deviation parameters of transportation to retailer phase of the seafood supply-chain.

First (A, B, C) and third (G, H, I) rows: battered-and-breaded fillets. Panels (A, G): German market. Panels (B, H): Netherlands market. Panels (C, I): domestic market. Second (D, E, F) and fourth (J, K, L) rows: crab-flavored sticks. Panels (D, J): Japanese market. Panels (E, K): South Korean market. Panels $(F, L)$ : domestic market. First (A, B, C) and second (D, E, F) rows: 20-y time horizon. Third (G, H, I) and fourth $(\mathrm{J}, \mathrm{K}, \mathrm{L})$ rows: 100-y time horizon. 


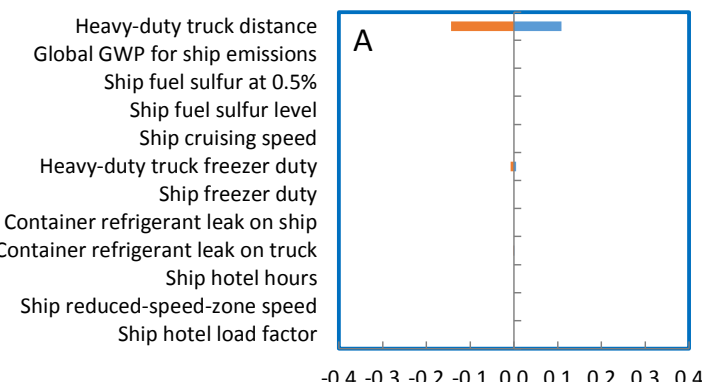

$\begin{array}{lllllllll}-0.4 & -0.3 & -0.2 & -0.1 & 0.0 & 0.1 & 0.2 & 0.3 & 0.4\end{array}$

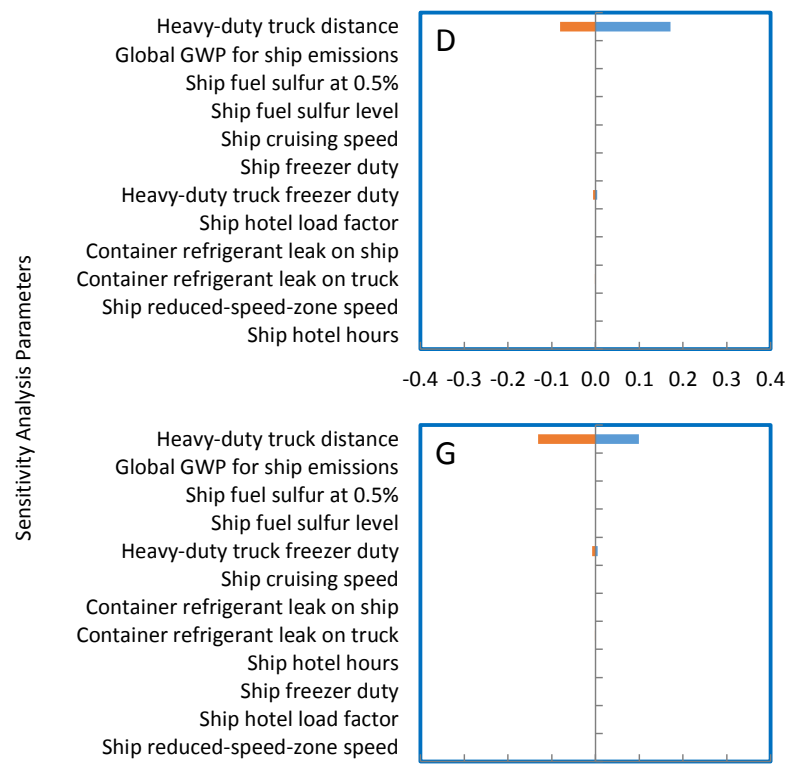

$\begin{array}{lllllllll}-0.4 & -0.3 & -0.2 & -0.1 & 0.0 & 0.1 & 0.2 & 0.3 & 0.4\end{array}$

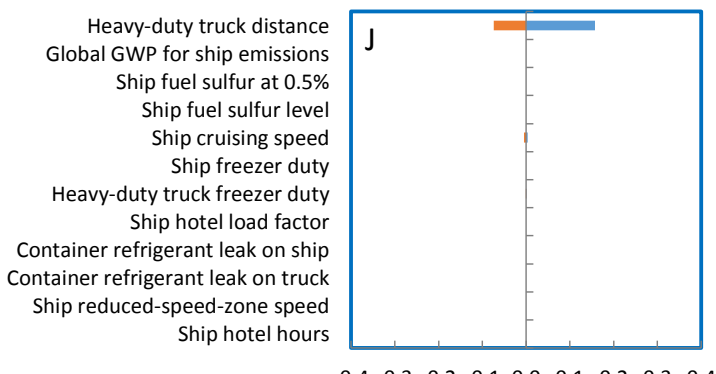

$\begin{array}{lllllllll}-0.4 & -0.3 & -0.2 & -0.1 & 0.0 & 0.1 & 0.2 & 0.3 & 0.4\end{array}$

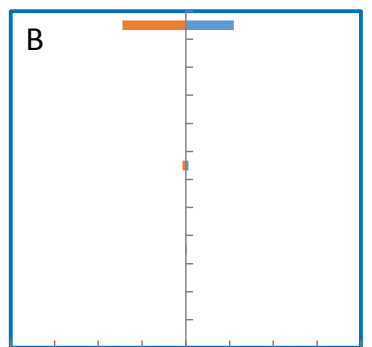

$\begin{array}{lllllllll}-0.4 & -0.3 & -0.2 & -0.1 & 0.0 & 0.1 & 0.2 & 0.3 & 0.4\end{array}$

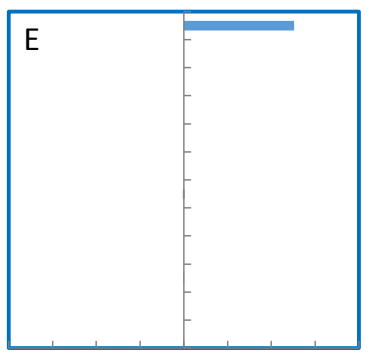

$\begin{array}{lllllllll}-0.4 & -0.3 & -0.2 & -0.1 & 0.0 & 0.1 & 0.2 & 0.3 & 0.4\end{array}$

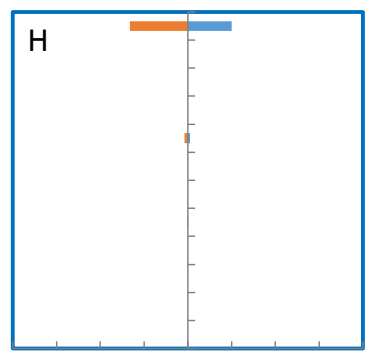

$\begin{array}{llllllllll}-0.4 & -0.3 & -0.2 & -0.1 & 0.0 & 0.1 & 0.2 & 0.3 & 0.4\end{array}$

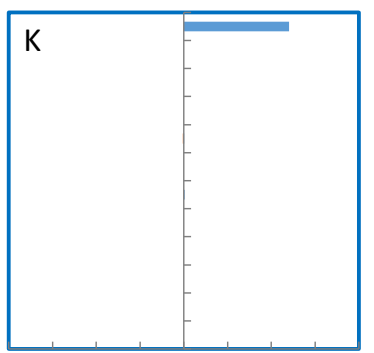

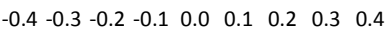

Decrease Increase

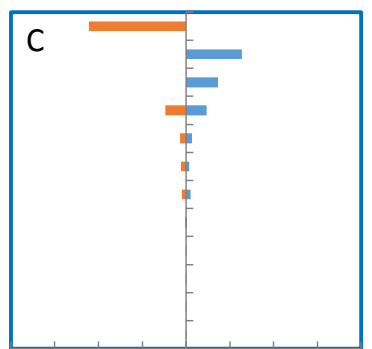

$\begin{array}{lllllllll}-0.4 & -0.3 & -0.2 & -0.1 & 0.0 & 0.1 & 0.2 & 0.3 & 0.4\end{array}$
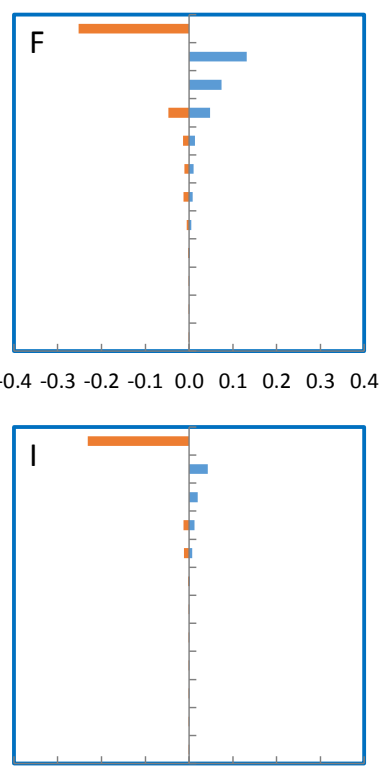

$\begin{array}{lllllllll}-0.4 & -0.3 & -0.2 & -0.1 & 0.0 & 0.1 & 0.2 & 0.3 & 0.4\end{array}$

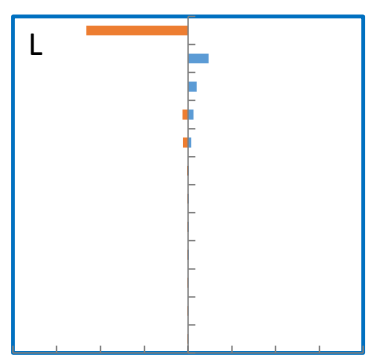

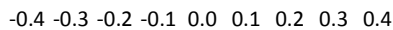

Change in climate forcing $\left(\mathrm{kg} \mathrm{CO}_{2} \mathrm{e} \mathrm{kg} \mathrm{product}{ }^{-1}\right)$

\section{Figure S11. Sensitivity analysis of highly uncertain parameters of transportation to retailer phase of the seafood supply-chain.}

First (A, B, C) and third (G, H, I) rows: battered-and-breaded fillets. Panels (A, G): German market. Panels (B, H): Netherlands market. Panels (C, I): domestic market. Second (D, E, F) and fourth (J, K, L) rows: crab-flavored sticks. Panels (D, J): Japanese market. Panels (E, K): South Korean market. Panels 
(F, L): domestic market. First (A, B, C) and second (D, E, F) rows: 20-y time horizon. Third (G, H, I) and fourth (J, K, L) rows: 100-y time horizon.

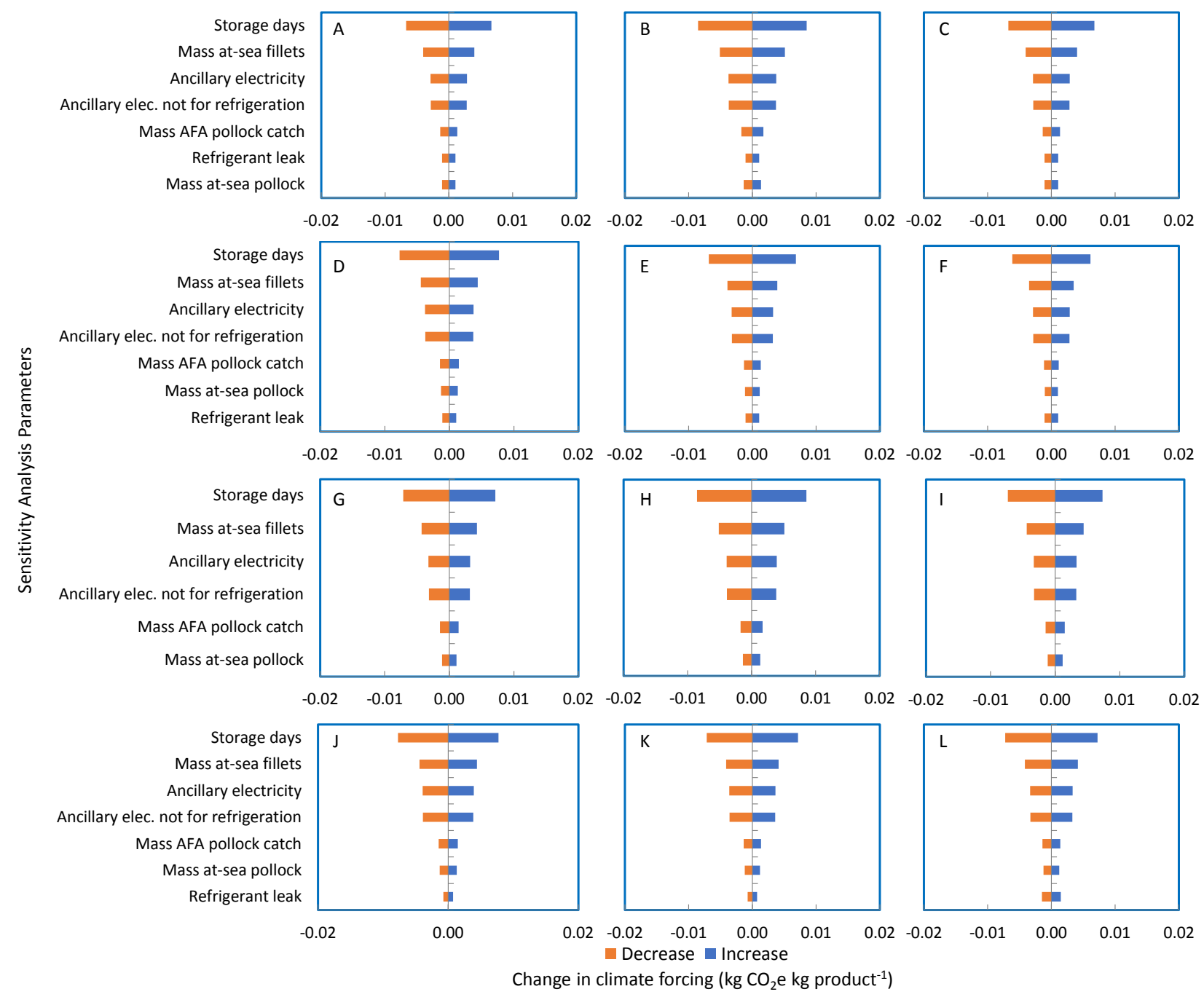

Figure S12. Sensitivity analysis of standard deviation and highly uncertain parameters of the retail phase.

The variables included in the standard deviation include the mass of at-sea pollock and the mass of pollock caught by the American Fisheries Act (AFA) fleet. The highly uncertain variables include storage time, electricity for ancillary operations, ancillary electricity not for refrigeration, and refrigerant leak. First (A, B, C) and third (G, H, I) rows: battered-and-breaded fillets. Panels (A, G): German market. Panels (B, H): Netherlands market. Panels (C, I): domestic market. Second (D, E, F) and fourth (J, K, L) rows: crab-flavored sticks. Panels (D, J): Japanese market. Panels (E, K): South Korean market. Panels 
(F, L): domestic market. First (A, B, C) and second (D, E, F) rows: 20-y time horizon. Third (G, H, I) and fourth $(\mathrm{J}, \mathrm{K}, \mathrm{L})$ rows: 100-y time horizon. 


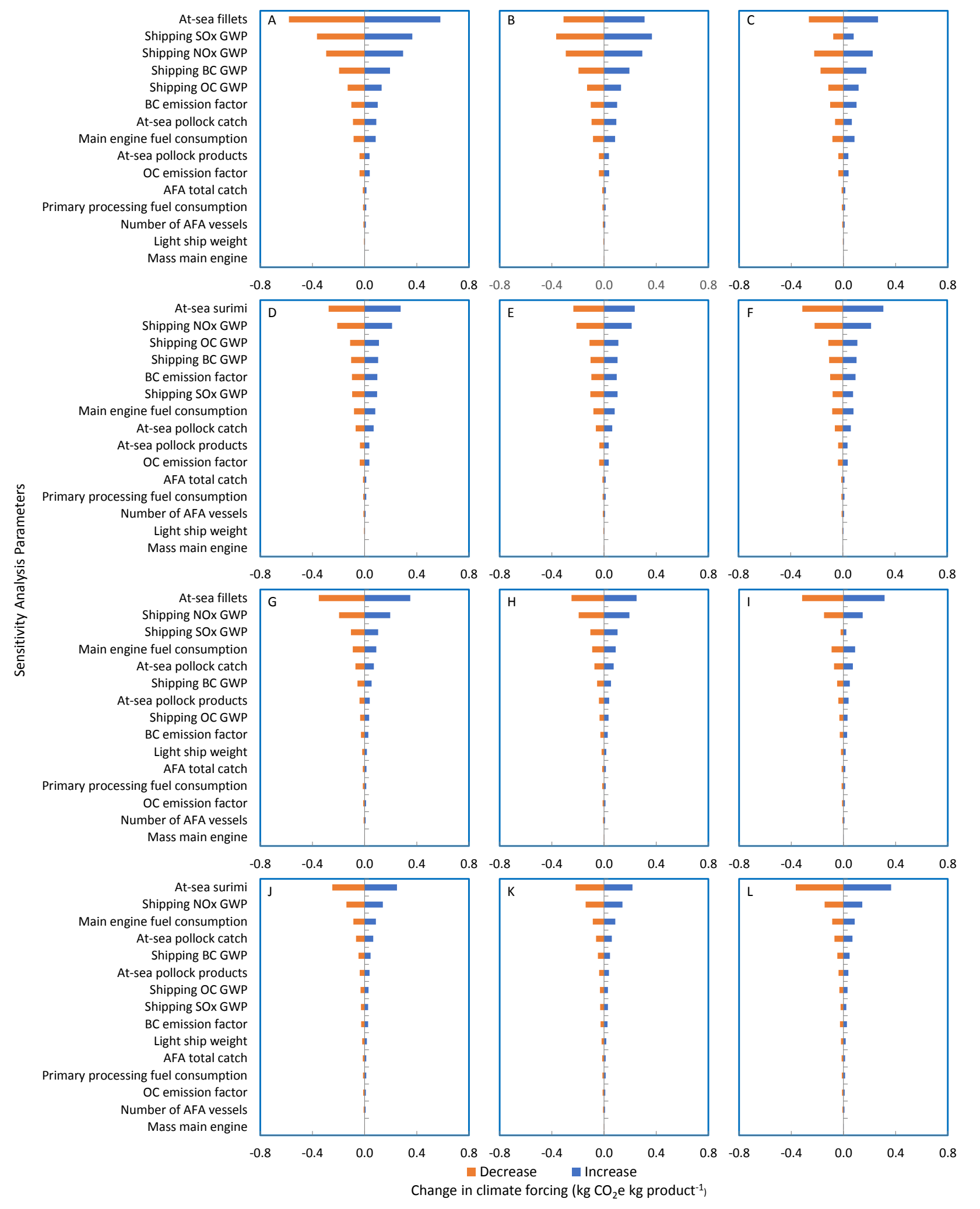


Figure S13. Sensitivity analysis of standard deviation of all phases of the seafood supply-chain.

The variables included in the standard deviation include the mass of at-sea pollock and the mass of pollock caught by the American Fisheries Act (AFA) fleet. The highly uncertain variables include processor storage time, and alternate emission factors. First (A, B, C) and third (G, H, I) rows: batteredand-breaded fillets. Panels (A, G): German market. Panels (B, H): Netherlands market. Panels (C, I): domestic market. Second (D, E, F) and fourth (J, K, L) rows: crab-flavored sticks. Panels (D, J): Japanese market. Panels (E, K): South Korean market. Panels (F, L): domestic market. First (A, B, C) and second (D, E, F) rows: 20-y time horizon. Third $(\mathrm{G}, \mathrm{H}, \mathrm{I})$ and fourth $(\mathrm{J}, \mathrm{K}, \mathrm{L})$ rows: $100-\mathrm{y}$ time horizon. 


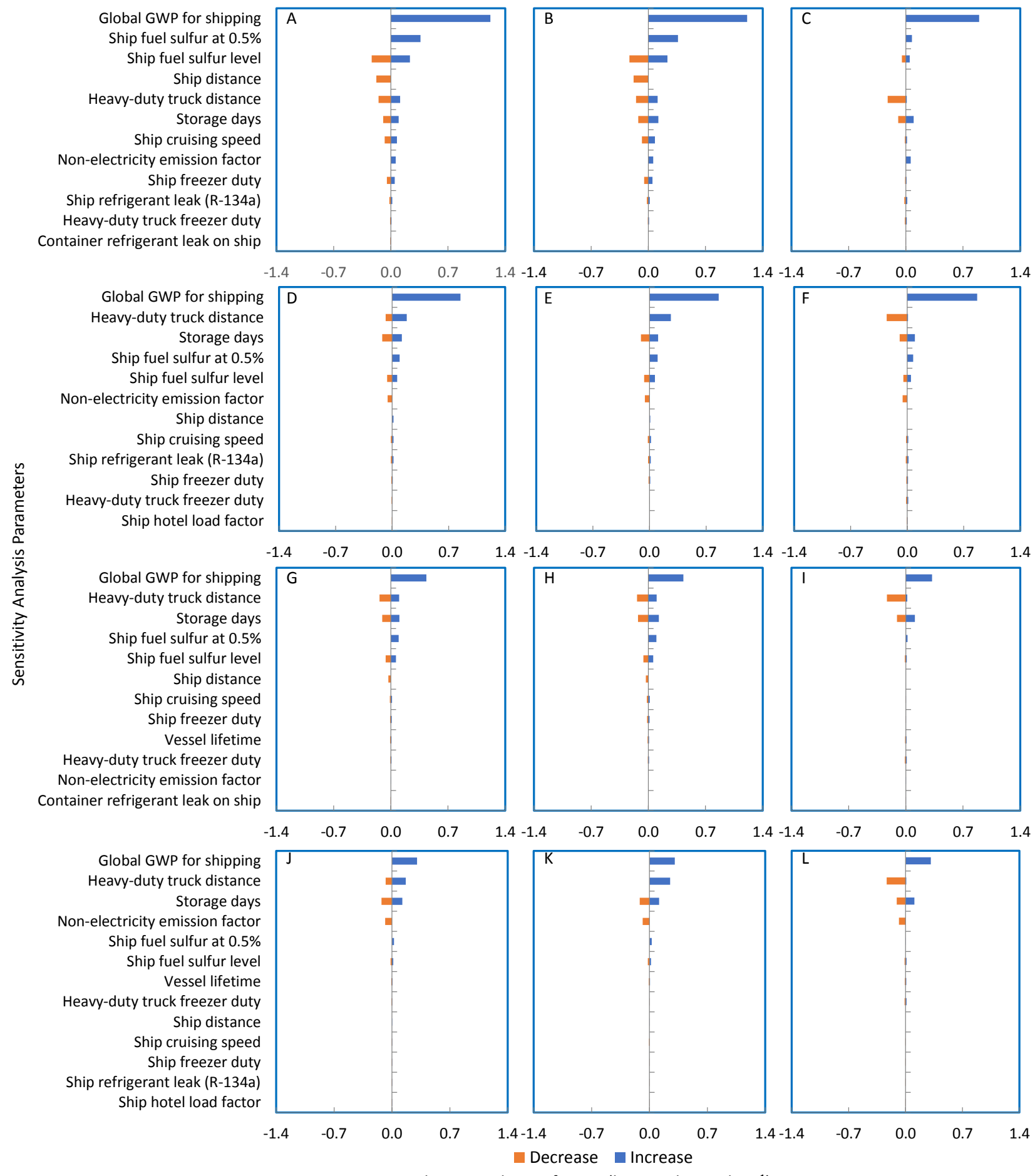

Change in climate forcing $\left(\mathrm{kg} \mathrm{CO}_{2} \mathrm{e} \mathrm{kg}\right.$ product $\left.{ }^{-1}\right)$ 
Figure S14. Sensitivity analysis of highly uncertain variables of all phases of the seafood supplychain.

First (A, B, C) and third (G, H, I) rows: battered-and-breaded fillets. Panels (A, G): German market. Panels (B, H): Netherlands market. Panels (C, I): domestic market. Second (D, E, F) and fourth (J, K, L) rows: crab-flavored sticks. Panels (D, J): Japanese market. Panels (E, K): South Korean market. Panels $(\mathrm{F}, \mathrm{L})$ : domestic market. First (A, B, C) and second (D, E, F) rows: 20-y time horizon. Third (G, H, I) and fourth $(\mathrm{J}, \mathrm{K}, \mathrm{L})$ rows: 100-y time horizon. 


\section{Tables (S1-S37)}

Table S1. Fuel consumption of the American Fisheries Act catcher-processor pelagic trawl fleet

\begin{tabular}{lll}
\hline Year & $\mathrm{n} \mathrm{Vessels}^{\mathrm{a}}$ & Fuel consumption (liters) $^{\mathrm{a}, \mathrm{b}}$ \\
\hline 2012 & 14 & $6.19( \pm 0.26) \times 10^{7}$ \\
2013 & 15 & $6.65( \pm 0.47) \times 10^{7}$ \\
2014 & 16 & $8.45( \pm 0.60) \times 10^{7}$ \\
2015 & 14 & $8.00( \pm 0.50) \times 10^{7}$
\end{tabular}

${ }^{\mathrm{a}}$ Source: (Fissel et al., 2016)

${ }^{\mathrm{b}}$ Mean (and 95\% confidence interval) 
Table S2. Mass and materials used in the manufacture of fishing gears obtained from the literature

\begin{tabular}{llll} 
Gear type & Gear material & $\begin{array}{l}\text { Amount } \\
\left(\mathrm{kg} \mathrm{ton}^{-1}\right)\end{array}$ & Study \\
\hline Longline & Steel & 0.09 & (Fulton, 2010) \\
& Nylon & 1.87 & \\
Pelagic trawl & Steel & 0.006 & \\
& Nylon & 0.008 & \\
& Lead & 0.052 & \\
& Polyethylene & 0.008 & \\
& Nylon & 5.17 & (Laso et al., 2018) \\
& Lead & 5.14 & \\
& Ethylene vinyl acetate (EVA) & 2.13 & \\
& Poly-steel & 0.46 & \\
& Maintenance nylon & 2.33 & \\
& Maintenance lead & 2.31 & \\
& Maintenance ethylene vinyl acetate & & \\
& (EVA) & 0.96 & (Svanes et al., 2011) \\
& Maintenance polysteel & 0.21 & \\
& Steel & 0.97 & \\
& Polyester & 0.65 & \\
& Poly-steel & 0.78 & \\
& Polypropylene & 0.52 & \\
\hline
\end{tabular}


Table S3. Vessel characteristics of the American Fisheries Act fleet ${ }^{\text {a }}$

\begin{tabular}{|c|c|c|c|c|c|c|}
\hline Vessel name & $\begin{array}{l}\text { Length } \\
\text { (m) }\end{array}$ & $\begin{array}{l}\text { Beam } \\
\text { length } \\
\text { (m) }\end{array}$ & $\begin{array}{l}\text { Gross } \\
\text { Tons }\end{array}$ & Power $(\mathrm{kW})$ & $\begin{array}{l}\text { Hull } \\
\text { Type }\end{array}$ & Refrigeration \\
\hline ALASKA OCEAN & 115 & 18.3 & 4555 & 4661 & Steel & Y \\
\hline AMERICAN DYNASTY & 83 & 16.5 & 5111 & 4847 & Steel & $\mathrm{Y}$ \\
\hline AMERICAN ENTERPRISE & 64 & 14.3 & 1537 & 2237 & Steel & Y \\
\hline AMERICAN TRIUMPH & 87 & 16.5 & 5015 & 6085 & Steel & \\
\hline ARCTIC FJORD & 84 & 15.1 & 3326 & 4519 & Steel & $\mathrm{Y}$ \\
\hline ARCTIC STORM & 102 & 14.8 & 4068 & 3729 & Steel & $\mathrm{Y}$ \\
\hline ENDURANCE & 85 & 18.0 & 2117 & 3952 & Steel & $\mathrm{Y}$ \\
\hline HIGHLAND LIGHT & 82 & 12.8 & 2417 & 4288 & Steel & Y \\
\hline ISLAND ENTERPRISE & 93 & 13.7 & 2766 & 3579 & Steel & $\mathrm{Y}$ \\
\hline KATIE ANN & 90 & 13.5 & 1593 & 3281 & Steel & $\mathrm{Y}$ \\
\hline KODIAK ENTERPRISE & 80 & 13.4 & 1584 & 4474 & Steel & Y \\
\hline NORTHERN EAGLE & 104 & 15.8 & 5190 & 4922 & Steel & Y \\
\hline NORTHERN GLACIER & 61 & 13.4 & 1109 & 2237 & Steel & Y \\
\hline NORTHERN HAWK & 104 & 15.8 & 5190 & 6562 & Steel & Y \\
\hline NORTHERN JAEGER & 102 & 15.5 & 3732 & 5369 & Steel & Y \\
\hline OCEAN PEACE & 61 & 15.2 & 1557 & 2051 & Steel & Y \\
\hline OCEAN ROVER & 78 & 16.5 & 4345 & 4474 & Steel & Y \\
\hline PACIFIC GLACIER & 84 & 15.2 & 3308 & 4922 & Steel & Y \\
\hline SEATTLE ENTERPRISE & 82 & 13.2 & 1519 & 2908 & Steel & Y \\
\hline STARBOUND & 91 & 14.6 & 2266 & 3729 & Steel & Y \\
\hline U.S. ENTERPRISE & 68 & 12.8 & 1319 & 2908 & Steel & $\mathrm{Y}$ \\
\hline
\end{tabular}


Table S4. Commercial marine compression ignition engine categories ${ }^{\text {a }}$

\begin{tabular}{llll}
\hline Category & Vessel type & Power Rating $(\mathrm{kW})$ & $\mathrm{n}$ Vessels \\
\hline 1 & Small harbor craft & $<1,000$ & \\
2 & Small ocean going propulsion & $1,000>3,000$ & 5 \\
3 & Ocean going propulsion & $>3,000$ & 16 \\
Unknown & & 21 \\
\hline${ }^{a}$ Source: (ICF International, 2009). & &
\end{tabular}


Table S5. Annual catch at the vessel level for the EBS ${ }^{\text {a }}$ catcher-processor AFA ${ }^{\text {b }}$ fleet

\begin{tabular}{|c|c|c|c|c|c|c|c|c|}
\hline Vessel Name & $\begin{array}{l}\text { Pollock } \\
2012^{\mathrm{c}} \\
(\mathrm{mt})\end{array}$ & $\begin{array}{l}\text { Bycatch } \\
2012^{\mathrm{c}} \\
(\mathrm{mt})\end{array}$ & $\begin{array}{l}\text { Pollock } \\
2013^{\mathrm{d}} \\
(\mathrm{mt})\end{array}$ & $\begin{array}{l}\text { Bycatch } \\
2013^{d} \\
(\mathrm{mt})\end{array}$ & $\begin{array}{l}\text { Pollock } \\
2014^{\mathrm{e}} \\
(\mathrm{mt})\end{array}$ & $\begin{array}{l}\text { Bycatch } \\
2014^{\mathrm{e}} \\
(\mathrm{mt})\end{array}$ & $\begin{array}{l}\text { Pollock } \\
2015^{\mathrm{f}} \\
(\mathrm{mt})\end{array}$ & $\begin{array}{l}\text { Bycatch } \\
2015^{\mathrm{f}} \\
(\mathrm{mt})\end{array}$ \\
\hline Alaska Ocean & 35,300 & 1,748 & 41,835 & 1,853 & 39,112 & 1,037 & 41,780 & 1,076 \\
\hline American Dynasty & 35,685 & 2,588 & 38,547 & 2,793 & 39,029 & 2,032 & 41,572 & 1,487 \\
\hline American Triumph & 36,783 & 3,056 & 38,275 & 3,238 & 38,815 & 2,958 & 39,336 & 905 \\
\hline Arctic Fjord & 25,746 & 870 & 34,034 & 753 & 27,690 & 655 & 28,448 & 449 \\
\hline Arctic Storm & 28,903 & 5,051 & 11,807 & 2,880 & 29,604 & 3,907 & 30,196 & 1,139 \\
\hline Island Enterprise & 23,490 & 941 & 23,666 & 795 & 25,323 & 465 & 27,600 & 328 \\
\hline Katie Ann & 573 & 5,625 & 1,242 & 15,898 & 1,346 & 9,525 & 751 & 3,720 \\
\hline Kodiak Enterprise & 20,451 & 1,568 & 27,239 & 740 & 19,695 & 1,369 & 24,626 & 480 \\
\hline Northern Eagle & 37,912 & 2,673 & 43,515 & 4,034 & 41,940 & 2,615 & 39,723 & 1,625 \\
\hline Northern Glacier & 698 & 10,561 & 489 & 6,834 & 700 & 8,420 & 667 & 6,352 \\
\hline Northern Hawk & 20,823 & 978 & 22,008 & 647 & 22,015 & 317 & 22,352 & 352 \\
\hline Northern Jaeger & 37,139 & 3,537 & 38,389 & 3,597 & 36,852 & 2,972 & 38,157 & 1,065 \\
\hline Ocean Rover & 38,148 & 3,014 & 34,126 & 3,276 & 38,325 & 2,621 & 40,667 & 1,789 \\
\hline Pacific Glacier & 30,931 & 993 & 29,623 & 752 & 29,849 & 477 & 32,761 & 428 \\
\hline Seattle Enterprise & 28,946 & 1,834 & 30,119 & 760 & 30,358 & 1,453 & 25,809 & 377 \\
\hline Starbound & 23,896 & 1,063 & 25,839 & 893 & 25,520 & 840 & 25,006 & 605 \\
\hline TOTALS & 425,424 & 46,101 & 440,753 & 49,741 & 446,173 & 41,665 & 459,451 & 22,177 \\
\hline
\end{tabular}

${ }^{\mathrm{a}}$ Eastern Bering Sea (EBS)

${ }^{\mathrm{b}}$ American Fisheries Act (AFA)

${ }^{c}$ Source: (North Pacific Fishery Management Council, 2013)

${ }^{\mathrm{d}}$ Source: (North Pacific Fishery Management Council, 2014)

e Source: (North Pacific Fishery Management Council, 2015)

${ }^{\mathrm{f}}$ Source: (North Pacific Fishery Management Council, 2016) 
Table S6. Bering Sea \& Aleutian Islands at-sea and shoreside production of pollock product ${ }^{\text {a }}$

\begin{tabular}{|c|c|c|c|c|}
\hline \multirow[t]{2}{*}{ Product } & 2012 & 2013 & 2014 & 2015 \\
\hline & \multicolumn{4}{|c|}{ (metric tons) } \\
\hline \multicolumn{5}{|l|}{ At-sea } \\
\hline Whole fish & 240 & 160 & 310 & 1,110 \\
\hline Head and gut & 25,540 & 37,280 & 34,770 & 25,380 \\
\hline Roe & 9,300 & 8,370 & 11,710 & 12,010 \\
\hline Deep-skin fillets & 36,840 & 36,830 & 32,680 & 34,560 \\
\hline Other Fillets & 47,550 & 59,630 & 63,680 & 57,440 \\
\hline Surimi & 77,930 & 80,850 & 87,810 & 95,940 \\
\hline Minced fish & 25,060 & 23,470 & 19,980 & 19,710 \\
\hline Fish meal & 21,080 & 20,980 & 23,250 & 26,450 \\
\hline Other Products & 10,570 & 12,210 & 13,570 & 12,600 \\
\hline \multicolumn{5}{|l|}{ Shoreside } \\
\hline Whole fish & 1,470 & 1,650 & 1,090 & 680 \\
\hline Head and gut & 3,610 & 3,690 & 2,770 & \\
\hline Roe & 7,180 & 5,550 & 8,890 & 6,740 \\
\hline Deep-skin fillets & 18,650 & 14,760 & 11,010 & 9,220 \\
\hline Other Fillets & 43,510 & 59,660 & 68,410 & 65,800 \\
\hline Surimi & 79,210 & 80,810 & 83,520 & 91,800 \\
\hline Minced fish & 5,960 & 7,270 & 6,090 & 5,470 \\
\hline Fish meal & 31,440 & 32,890 & 33,600 & 34,590 \\
\hline Other Products & 27,580 & 20,780 & 22,400 & 21,440 \\
\hline
\end{tabular}


Table S7. Annual disposition of frozen Alaska pollock fillet blocks to top three markets

\begin{tabular}{ccccc}
\hline Year & $\begin{array}{c}\text { Germany } \\
(\mathrm{kg})\end{array}$ & $\begin{array}{c}\text { a,b } \\
(\mathrm{kg})\end{array}$ & $\begin{array}{c}\text { Total Exports } \\
(\mathrm{kg})\end{array}$ & $\begin{array}{c}\text { United States } \\
{ }^{\mathrm{a}}\end{array}$ \\
\hline 2012 & $37,346,658$ & $21,567,553$ & $79,316,596$ & $67,233,404$ \\
2013 & $66,901,467$ & $25,420,085$ & $114,359,645$ & $56,520,355$ \\
2014 & $81,540,580$ & $24,831,764$ & $131,818,585$ & $43,961,415$ \\
2015 & $74,102,716$ & $25,392,231$ & $124,291,619$ & $42,728,381$ \\
\hline
\end{tabular}

${ }^{\mathrm{a}}$ Source: (National Marine Fisheries Service, 2016)

${ }^{\mathrm{b}}$ Fillet production is the sum of deep-skin fillets and "other fillets" (conf. Table S6 of this study).

${ }^{\mathrm{c}}$ Estimated as the difference between the total production of fillets (conf. Table S6 of this study) and the total exports (sum of all international exports) 
Table S8. Annual disposition of frozen Alaska pollock surimi blocks to top three markets

\begin{tabular}{ccccc}
\hline Year & $\begin{array}{c}\text { Japan }^{\text {a,b }} \\
(\mathrm{kg})\end{array}$ & $\begin{array}{c}\text { South Korea } \\
(\mathrm{kg})\end{array}$ & $\begin{array}{c}\text { Total Exports } \\
(\mathrm{kg})\end{array}$ & $\begin{array}{c}\text { United States } \\
(\mathrm{kg})\end{array}$ \\
\hline 2012 & $67,604,865$ & $44,952,472$ & $167,198,699$ & $16,214,000$ \\
2013 & $56,291,799$ & $61,447,960$ & $170,280,476$ & $9,373,000$ \\
2014 & $71,889,091$ & $58,847,130$ & $183,183,521$ & $22,278,000$ \\
2015 & $81,830,082$ & $60,406,689$ & $187,740,000$ & $16,226,710$ \\
\hline
\end{tabular}

${ }^{a}$ Annual disposition of frozen Alaskan pollock surimi blocks estimated as the product of the annual fraction of surimi products produced by at-sea processors by exports of surimi.

${ }^{b}$ Source: (National Marine Fisheries Service, 2016)

${ }^{\mathrm{c}}$ Annual disposition estimated as the difference between the total production of surimi blocks (conf. Table S6 of this study) and the total exports multiplied by the annual production by at-sea processors. 
Table S9. Container ship distances to ports by route as estimated by distance calculators

\begin{tabular}{llllll}
\hline & $\begin{array}{l}\text { Port of } \\
\text { Hamburg } \\
(\mathrm{km})\end{array}$ & $\begin{array}{l}\text { Port of } \\
\text { Rotterdam } \\
(\mathrm{km})\end{array}$ & $\begin{array}{l}\text { Port of } \\
\text { Nagoya } \\
(\mathrm{km})\end{array}$ & $\begin{array}{l}\text { Port of } \\
\text { Busan } \\
(\mathrm{km})\end{array}$ & $\begin{array}{l}\text { Port of } \\
\text { Seattle } \\
(\mathrm{km})\end{array}$ \\
\hline Route 1 & $11,997^{\mathrm{a}, \mathrm{b}}$ & $11,908^{\mathrm{a}, \mathrm{b}}$ & $4,997^{\mathrm{c}, \mathrm{d}}$ & $5,502^{\mathrm{d}, \mathrm{e}}$ & $3,180^{\mathrm{d}, \mathrm{f}}$ \\
Route 2 & $19,150^{\mathrm{d}, \mathrm{g}, \mathrm{h}}$ & $18,681^{\mathrm{d}, \mathrm{g}, \mathrm{i}}$ & $5,713^{\mathrm{d}, \mathrm{j}}$ & $5,908^{\mathrm{d}, \mathrm{k}}$ & \\
Route 3 & $26,245^{\mathrm{d}, \mathrm{l}, \mathrm{m}}$ & $25,745^{\mathrm{d}, \mathrm{l}, \mathrm{n}}$ & $6,202^{\mathrm{d}, \mathrm{o}}$ & $6,632^{\mathrm{d}, \mathrm{p}}$ & \\
Route $4^{19,479^{\mathrm{d}, \mathrm{g}, \mathrm{q}}}$ & $18,983^{\mathrm{d}, \mathrm{g}, \mathrm{r}}$ & & & & \\
\hline
\end{tabular}

${ }^{a}$ Note: the Northwest Passage is not currently used by container ships (Schøyen and Bråthen, 2011; Headlands, R. K. et al., 2018).

${ }^{\mathrm{b}}$ Source: Distances.com, available at: www.distances.com/; sea mode was selected.

${ }^{\mathrm{c}}$ Via Ise Bay.

${ }^{\mathrm{d}}$ Source: (Marine Traffic, 2018)

${ }^{\mathrm{e}}$ Via Cape Crillon.

${ }^{\mathrm{f}} 1,217 \mathrm{~km}$ within emission control area (ECA).

${ }^{\mathrm{g}}$ Panama Canal, Mona Passage, English Channel.

${ }^{\mathrm{h}} 1,339 \mathrm{~km}$ within ECA.

i $733.4 \mathrm{~km}$ within ECA.

${ }^{\mathrm{j}}$ Bussol Strait, Cape Crillon, Tsugaru Straits, Ise Bay.

${ }^{k}$ Kiisuido Strait, Kanmon Straight.

${ }^{1}$ Bussol Strait, Korea Strait, Luzon Strait, Singapore Strait, Bab el-Mandeb Strait, Suez Canal, Strait of Sicily, Strait of Gibraltar, English Channel;

$\mathrm{m} 1,272 \mathrm{~km}$ within ECA.

n $772 \mathrm{~km}$ within ECA.

${ }^{\circ}$ Bussol Strait, Tsugaru Strait, Kanmon Strait, Bungo Channel, Ise Bay.

${ }^{\mathrm{p}}$ Bussol Strait, Tsugaru Strait, Kanmon Strait, Bungo Channel.

${ }^{\mathrm{q}} 1,252 \mathrm{~km}$ within ECA.

${ }^{\mathrm{r}} 757 \mathrm{~km}$ within ECA. 
Table S10. Estimated truck driving distances and driving times from arrival Ports to processors

\begin{tabular}{|c|c|c|c|c|}
\hline Processor $^{\mathrm{a}}$ & City & $\begin{array}{l}\text { Distance } \\
(\mathrm{km})\end{array}$ & Time & Route \\
\hline \multicolumn{5}{|l|}{ Germany } \\
\hline Frozen Fish International ${ }^{\mathrm{b}}$ & Bremerhaven & 162 & 1 hour $36 \mathrm{~min}$ & A1 and A27 \\
\hline Frozen Fish International ${ }^{\mathrm{b}}$ & Bremerhaven & 132 & 1 hour $46 \mathrm{~min}$ & A1 \\
\hline Frozen Fish International ${ }^{\mathrm{b}}$ & Bremerhaven & 130 & 1 hour 46 min & B71 \\
\hline Frosta $^{c}$ & Bremerhaven & 164 & 1 hour $34 \mathrm{~min}$ & A1 and A27 \\
\hline Frosta $^{c}$ & Bremerhaven & 132 & 1 hour $44 \mathrm{~min}$ & A1 \\
\hline Frosta $^{c}$ & Bremerhaven & 129 & 1 hour $44 \mathrm{~min}$ & B71 \\
\hline Pickenpack ${ }^{\mathrm{d}}$ & Ihlow & 231 & 2 hour $19 \min$ & A1 and A28 \\
\hline Pickenpack ${ }^{\mathrm{d}}$ & Ihlow & 254 & 2 hour $42 \min$ & A1 \\
\hline \multicolumn{5}{|l|}{ Netherlands } \\
\hline D. Visser Frozen Seafood ${ }^{\mathrm{e}}$ & Urk & 180 & 1 hour $45 \mathrm{~min}$ & A6 \\
\hline D. Visser Frozen Seafood ${ }^{\mathrm{e}}$ & Urk & 176 & 1 hour $45 \mathrm{~min}$ & A4 and A6 \\
\hline Fish Masters ${ }^{\mathrm{f}}$ & Urk & 179 & 1 hour $43 \mathrm{~min}$ & A6 \\
\hline Isola Fish ${ }^{\mathrm{g}}$ & Urk & 180 & 1 hour $44 \mathrm{~min}$ & A6 \\
\hline \multicolumn{5}{|l|}{ Japan } \\
\hline Tomiso Co., Ltd. ${ }^{\mathrm{h}}$ & Nagoya City & 12.2 & $20 \mathrm{~min}$ & 名古屋高速4号東海線 \\
\hline Tomiso Co., Ltd. ${ }^{\mathrm{h}}$ & Nagoya City & 12.7 & $27 \mathrm{~min}$ & 名古屋高速 4 号東海線 and 久屋大通 \\
\hline \multicolumn{5}{|l|}{ South Korea } \\
\hline Hansung Enterprise Co. Ltd. ${ }^{\mathrm{i}, \mathrm{j}}$ & Busan & 2.5 & $4.7 \mathrm{~min}$ & \\
\hline \multicolumn{5}{|c|}{$\begin{array}{l}\text { a Processors selected from internet search of major product processing facilities. } \\
{ }^{\mathrm{b}} \text { Google map address: Frozen Fish International GmbH, Am Lunedeich 115, } 27572 \text { Bremerhaven, Germany. } \\
{ }^{\mathrm{c}} \text { Google map address: FRoSTA AG, Am Lunedeich 116D, } 27572 \text { Bremerhaven, Germany. } \\
{ }^{\mathrm{d}} \text { Google map address: Pickenpack Seafoods GmbH, Schmiedestraße 16, 26632 Ihlow, Germany. } \\
{ }^{\mathrm{e}} \text { Google map address: D. Visser Frozen Seafood, Wijk } 6135,8321 \text { VH Urk, Netherlands } \\
{ }^{\mathrm{f}} \text { Google map address: Fishmasters BV, Noordgat 1, 8321 ME Urk, Netherlands } \\
{ }^{\mathrm{g}} \text { Google map address: Isola Fish B.V., Industrierondweg 11, 8321 EA Urk, Netherlands } \\
{ }^{\mathrm{h}} \text { Google map address: Tomiso Co., Ltd., Nagoya, Aichi Prefecture, Japan. } \\
{ }^{\mathrm{I}} \text { Google map address: Hansung Enterprise Co. Ltd., 71-ka Daegyo-dong, Yeongdo-ku, Busan. } \\
{ }^{\mathrm{j}} \text { Driving directions, estimated distance, and estimated drive time were not available from Google maps; distance estimated from } \\
\text { map legend and measurement of route. }\end{array}$} \\
\hline
\end{tabular}


Table S11. Estimated truck driving distances and driving times from processors to retail distributors

\begin{tabular}{lcc}
\hline Market & $\begin{array}{c}\text { Distance } \\
(\mathrm{km})\end{array}$ & $\begin{array}{c}\text { Time } \\
\text { (hours) }\end{array}$ \\
\cline { 1 - 2 } German & $1,500^{\mathrm{a}}$ & $17^{\mathrm{b}}$ \\
Netherlands & $1,500^{\mathrm{a}}$ & $17^{\mathrm{b}}$ \\
Japan & $1,016^{\mathrm{c}}$ & $11^{\mathrm{b}}$ \\
South Korea & $391^{\mathrm{d}, \mathrm{e}}$ & $4.3^{\mathrm{b}}$ \\
United States & $2,341^{\mathrm{f}}$ & $26^{\mathrm{b}}$ \\
\hline${ }^{\mathrm{a}}$ Average distance all food travels within continental Europe (Pretty et al., 2005). \\
${ }^{\mathrm{b}}$ Assuming truck speed of 90 km $\mathrm{h}^{-1}$. \\
${ }^{\mathrm{c}}$ Average of truck transport distances of tomatoes from growers to retailers (690 km from Aomori to Tokyo; 1,130 km from \\
Fukuoka to Tokyo; 845 km from Hokkaido to Tokyo, and 1,400 from Kagoshima to Tokyo) as reported in (Roy et al., 2008). \\
d Seoul-Busan corridor where import and export commodities are mainly shipped in Korea (Park and Hahn, 2015). \\
${ }^{\mathrm{e}}$ Distance estimated using a distance calculator (www.distance.to/Busan/Seoul). \\
${ }^{\mathrm{f}}$ Source: (US Census Bureau, 2013)
\end{tabular}


Table S12. Transportation inputs of frozen Alaska pollock fillet blocks for three different port destinations

\begin{tabular}{|c|c|c|c|c|}
\hline Item & Units & Germany ${ }^{\mathrm{a}, \mathrm{b}}$ & Netherlands ${ }^{\mathrm{a}, \mathrm{c}}$ & United States ${ }^{\mathrm{a}, \mathrm{d}}$ \\
\hline \multicolumn{5}{|l|}{ Inputs } \\
\hline Frozen fillet blocks & $\mathrm{kg}$ & $2.64( \pm 0.80) \times 10^{7}$ & $9.90( \pm 0.89) \times 10^{6}$ & $2.14( \pm 0.65) \times 10^{7}$ \\
\hline Packaging & $\mathrm{kg}$ & $7.08( \pm 0.21) \times 10^{5}$ & $2.65( \pm 0.24) \times 10^{5}$ & $5.74( \pm 1.74) \times 10^{5}$ \\
\hline Pallets & $\mathrm{kg}$ & $4.23( \pm 1.28) \times 10^{5}$ & $1.58( \pm 0.14) \times 10^{5}$ & $3.43( \pm 1.04) \times 10^{5}$ \\
\hline Container & $\mathrm{kg}$ & $2.51( \pm 0.76) \times 10^{6}$ & $9.38( \pm 0.84) \times 10^{5}$ & $2.03( \pm 0.62) \times 10^{3}$ \\
\hline Gross shipping mass & $\mathrm{kg}$ & $3.01( \pm 0.91) \times 10^{7}$ & $1.13( \pm 0.10) \times 10^{7}$ & $2.23( \pm 0.70) \times 10^{7}$ \\
\hline \multicolumn{5}{|c|}{ Container ship from Dutch Harbor to secondary processor } \\
\hline $\mathrm{HFO}^{\mathrm{e}}$ for ship main and auxiliary engines & $\mathrm{kg}$ & $1.28( \pm 0.39) \times 10^{6}$ & $4.77( \pm 0.43) \times 10^{5}$ & \\
\hline $\mathrm{HFO}^{\mathrm{e}}$ for temperature-controlled container & $\mathrm{kg}$ & $2.44( \pm 0.74) \times 10^{5}$ & $9.07( \pm 0.82) \times 10^{4}$ & \\
\hline $\mathrm{MGO}^{\mathrm{f}}$ for ship main and auxiliary engines & $\mathrm{kg}$ & $1.68( \pm 0.45) \times 10^{5}$ & $7.37( \pm 0.50) \times 10^{4}$ & \\
\hline $\mathrm{MGO}^{\mathrm{f}}$ for temperature-controlled container & $\mathrm{kg}$ & $3.18( \pm 0.86) \times 10^{4}$ & $1.40( \pm 0.09) \times 10^{4}$ & \\
\hline Coolant ${ }^{\mathrm{g}}$ for ship air conditioning & $\mathrm{kg}$ & $1.02( \pm 0.31)$ & $0.64( \pm 0.06)$ & \\
\hline $\begin{array}{l}\text { Coolant }{ }^{\mathrm{h}} \text { for temperature-controlled } \\
\text { container }\end{array}$ & $\mathrm{kg}$ & $5.21( \pm 1.57) \times 10^{1}$ & $2.91( \pm 0.26) \times 10^{1}$ & \\
\hline \multicolumn{5}{|c|}{ Heavy-duty truck transportation from port to secondary processor } \\
\hline $\mathrm{ULSD}^{\mathrm{i}}$ for truck main engine & $\mathrm{kg}$ & $8.70( \pm 0.26) \times 10^{4}$ & $2.00( \pm 0.28) \times 10^{4}$ & $6.45( \pm 1.96) \times 10^{3}$ \\
\hline ULSD $^{\mathrm{i}}$ for temperature-controlled container & $\mathrm{kg}$ & $7.29( \pm 2.20) \times 10^{3}$ & $1.57( \pm 0.14) \times 10^{3}$ & $3.39( \pm 1.03) \times 10^{3}$ \\
\hline $\begin{array}{l}\text { Coolant }{ }^{\mathrm{h}} \text { for temperature-controlled } \\
\text { container }\end{array}$ & $\mathrm{kg}$ & $0.35( \pm 0.11)$ & $8.80( \pm 0.79) \times 10^{-2}$ & $3.65( \pm 1.11) \times 10^{-2}$ \\
\hline \multicolumn{5}{|l|}{ Outputs } \\
\hline Frozen fillet blocks & $\mathrm{kg}$ & $2.64( \pm 0.80) \times 10^{7}$ & $9.90( \pm 0.89) \times 10^{6}$ & $2.14( \pm 0.65) \times 10^{6}$ \\
\hline Packaging & $\mathrm{kg}$ & $7.08( \pm 0.21) \times 10^{5}$ & $2.65( \pm 0.24) \times 10^{5}$ & $5.74( \pm 1.74) \times 10^{5}$ \\
\hline \multicolumn{5}{|c|}{$\begin{array}{l}{ }^{\mathrm{a}} \text { Mean (and standard deviation). The variation/error was propagated for mass of the pollock catch by the AFA fleet, fraction o } \\
\text { at-sea fillets of total pollock fillets (processed by catcher-processors and processed on-shore), fraction of at-sea surimi of total } \\
\text { pollock surimi (processed by catcher-processors and processed on-shore), and mass of fillets to top markets. } \\
\text { b Estimates based on transport of pollock fillet blocks from Port of Dutch Harbor to Port of Hamburg. } \\
{ }^{\mathrm{c}} \text { Estimates based on transport of pollock fillet blocks from Port of Dutch Harbor to Port of Rotterdam. } \\
{ }^{\mathrm{d}} \text { Estimates based on transport of pollock fillet blocks to secondary processor near Port of Dutch Harbor by heavy-duty truck. } \\
{ }^{\mathrm{e}} \text { Heavy fuel oil (HFO). } \\
{ }_{\mathrm{f}}^{\mathrm{f}} \text { Marine gas oil (MGO). } \\
{ }^{\mathrm{g}} \text { Refrigerant R-404a as coolant. } \\
{ }^{\mathrm{h}} \text { Refrigerant R-134a as coolant. }\end{array}$} \\
\hline
\end{tabular}


Table S13. Transportation inputs of frozen Alaska surimi fillet blocks for three different port destinations

\begin{tabular}{|c|c|c|c|c|}
\hline Item & Units & Japan ${ }^{\mathrm{a}, \mathrm{b}}$ & South Korea ${ }^{\mathrm{a}, \mathrm{c}}$ & United States ${ }^{\mathrm{a}, \mathrm{d}}$ \\
\hline \multicolumn{5}{|l|}{ Inputs } \\
\hline Frozen surimi blocks & $\mathrm{kg}$ & $2.55( \pm 0.41) \times 10^{7}$ & $2.06( \pm 0.29) \times 10^{7}$ & $5.89( \pm 1.96) \times 10^{6}$ \\
\hline Packaging & $\mathrm{kg}$ & $6.67( \pm 1.06) \times 10^{5}$ & $5.37( \pm 0.77) \times 10^{5}$ & $1.54( \pm 0.51) \times 10^{5}$ \\
\hline Pallets & $\mathrm{kg}$ & $4.08( \pm 0.65) \times 10^{5}$ & $3.29( \pm 0.47) \times 10^{5}$ & $9.42( \pm 0.31) \times 10^{4}$ \\
\hline Container & $\mathrm{kg}$ & $2.42( \pm 0.38) \times 10^{6}$ & $1.95( \pm 0.28) \times 10^{6}$ & $5.58( \pm 1.85) \times 10^{2}$ \\
\hline Gross shipping mass & $\mathrm{kg}$ & $2.90( \pm 0.46) \times 10^{7}$ & $2.34( \pm 0.33) \times 10^{7}$ & $6.14( \pm 2.04) \times 10^{6}$ \\
\hline \multicolumn{5}{|c|}{ Container ship from Dutch Harbor to secondary processor } \\
\hline $\mathrm{HFO}^{\mathrm{e}}$ for ship main and auxiliary engines & $\mathrm{kg}$ & $5.39( \pm 0.80) \times 10^{5}$ & $4.82( \pm 0.64) \times 10^{5}$ & \\
\hline $\mathrm{HFO}^{\mathrm{e}}$ for temperature-controlled container & $\mathrm{kg}$ & $1.02( \pm 0.15) \times 10^{5}$ & $9.16( \pm 1.22) \times 10^{5}$ & \\
\hline Coolant ${ }^{\mathrm{g}}$ for ship air conditioning & $\mathrm{kg}$ & $5.08( \pm 0.81) \times 10^{-1}$ & $3.48( \pm 0.50) \times 10^{-1}$ & \\
\hline $\begin{array}{l}\text { Coolant }{ }^{\mathrm{h}} \text { for temperature-controlled } \\
\text { container }\end{array}$ & $\mathrm{kg}$ & $2.31( \pm 0.40) \times 10^{1}$ & $2.00( \pm 0.29) \times 10^{1}$ & \\
\hline \multicolumn{5}{|c|}{ Heavy-duty truck transportation from port to secondary processor } \\
\hline $\mathrm{ULSD}^{\mathrm{i}}$ for truck main engine & $\mathrm{kg}$ & $5.66( \pm 0.90) \times 10^{3}$ & $9.16( \pm 1.62) \times 10^{2}$ & $1.77( \pm 0.59) \times 10^{3}$ \\
\hline ULSD $^{\mathrm{i}}$ for temperature-controlled container & $\mathrm{kg}$ & $1.76( \pm 0.28) \times 10^{3}$ & $2.81( \pm 0.40) \times 10^{2}$ & $2.42( \pm 0.80) \times 10^{2}$ \\
\hline $\begin{array}{l}\text { Coolant }{ }^{\mathrm{h}} \text { for temperature-controlled } \\
\text { container }\end{array}$ & $\mathrm{kg}$ & $7.29( \pm 0.33) \times 10^{-2}$ & $4.54( \pm 0.93) \times 10^{-2}$ & $1.00( \pm 0.33) \times 10^{-2}$ \\
\hline \multicolumn{5}{|l|}{ Outputs } \\
\hline Frozen fillet blocks & $\mathrm{kg}$ & $2.55( \pm 0.41) \times 10^{7}$ & $2.06( \pm 0.29) \times 10^{7}$ & $5.89( \pm 1.96) \times 10^{6}$ \\
\hline Packaging & $\mathrm{kg}$ & $6.67( \pm 1.06) \times 10^{5}$ & $5.37( \pm 0.77) \times 10^{5}$ & $1.54( \pm 0.51) \times 10^{5}$ \\
\hline $\begin{array}{l}{ }^{\mathrm{a}} \text { Mean (and standard deviation). The variatio } \\
\text { at-sea fillets of total pollock fillets (processed } \\
\text { pollock surimi (processed by catcher-process } \\
\text { b } \text { Estimates based on transport of pollock fille } \\
{ }^{\mathrm{c}} \text { Estimates based on transport of pollock fille } \\
{ }^{\mathrm{d}} \text { Estimates based on transport of pollock fille } \\
{ }^{\mathrm{e}} \text { Heavy fuel oil (HFO). } \\
{ }^{\mathrm{f}} \text { Marine gas oil (MGO). } \\
{ }^{\mathrm{g}} \text { Refrigerant R-404a as coolant. } \\
{ }^{\mathrm{h}} \text { Refrigerant R-134a as coolant. } \\
{ }^{\mathrm{i}} \text { Ultra-low sulfur diesel (ULSD). }\end{array}$ & $\begin{array}{l}\text { arror wa } \\
\text { y catche } \\
\text { and pr } \\
\text { locks fr } \\
\text { locks fr } \\
\text { locks to }\end{array}$ & $\begin{array}{l}\text { propagated for mass } \\
\text {-processors and proce } \\
\text { cessed on-shore), and } \\
\text { m Port of Dutch Hark } \\
\text { m Port of Dutch Hart } \\
\text { secondary processor } 1\end{array}$ & $\begin{array}{l}\text { f the pollock catch by } \\
\text { ssed on-shore), fractio } \\
\text { mass of surimi to top } \\
\text { or to Port of Nagoya. } \\
\text { or to Port of Busan. } \\
\text { ear Port of Dutch Har }\end{array}$ & $\begin{array}{l}\text { AFA fleet, fraction } \\
\text { of at-sea surimi of tota } \\
\text { arkets. } \\
\text { r by heavy-duty truck. }\end{array}$ \\
\hline
\end{tabular}


Table S14. Transportation inputs for frozen Alaskan pollock battered-and-breaded fillets for three different retail markets

\begin{tabular}{|c|c|c|c|c|}
\hline Description & Units & Germany $^{\mathrm{a}}$ & Netherlands $^{\text {a }}$ & United States $^{\text {a }}$ \\
\hline \multicolumn{5}{|l|}{ Transportation to retail distribution center } \\
\hline Frozen battered-and-breaded fillets & $\mathrm{kg}$ & $4.75( \pm 1.43) \times 10^{7}$ & $1.78( \pm 0.16) \times 10^{7}$ & $3.85( \pm 0.87) \times 10^{7}$ \\
\hline Packaging & $\mathrm{kg}$ & $3.79( \pm 1.14) \times 10^{6}$ & $1.42( \pm 0.13) \times 10^{6}$ & $3.07( \pm 0.69) \times 10^{6}$ \\
\hline Pallets & $\mathrm{kg}$ & $7.99( \pm 2.36) \times 10^{5}$ & $2.99( \pm 0.26) \times 10^{5}$ & $6.48( \pm 1.46) \times 10^{6}$ \\
\hline Container & $\mathrm{kg}$ & $4.74( \pm 1.40) \times 10^{6}$ & $1.77( \pm 0.16) \times 10^{6}$ & $3.84( \pm 0.86) \times 10^{6}$ \\
\hline Gross shipping mass & $\mathrm{kg}$ & $5.68( \pm 1.71) \times 10^{7}$ & $2.13( \pm 0.19) \times 10^{7}$ & $4.61( \pm 1.04) \times 10^{7}$ \\
\hline \multicolumn{5}{|l|}{ Heavy-duty truck transportation } \\
\hline $\mathrm{ULSD}^{\mathrm{b}}$ for truck main engine & $\mathrm{kg}$ & $9.62( \pm 2.90) \times 10^{6}$ & $3.60( \pm 0.32) \times 10^{5}$ & \\
\hline $\mathrm{ULSD}^{\mathrm{b}}$ for temperature-controlled container & $\mathrm{kg}$ & $1.47( \pm 0.43) \times 10^{4}$ & $5.49( \pm 0.48) \times 10^{4}$ & \\
\hline $\begin{array}{l}\text { Coolant }{ }^{\mathrm{c}} \text { for temperature-controlled } \\
\text { container }\end{array}$ & $\mathrm{kg}$ & $6.08( \pm 1.80)$ & $2.28( \pm 0.20)$ & \\
\hline \multicolumn{5}{|l|}{ Container ship transportation } \\
\hline $\mathrm{HFO}^{\mathrm{d}}$ for ship main and auxiliary engines & $\mathrm{kg}$ & & & $3.13( \pm 0.70) \times 10^{5}$ \\
\hline $\mathrm{HFO}^{\mathrm{d}}$ for temperature-controlled container & $\mathrm{kg}$ & & & $6.10( \pm 1.34) \times 10^{4}$ \\
\hline $\mathrm{MGO}^{\mathrm{e}}$ for ship main and auxiliary engines & $\mathrm{kg}$ & & & $1.87( \pm 0.40) \times 10^{5}$ \\
\hline $\mathrm{MGO}^{\mathrm{e}}$ for temperature-controlled container & $\mathrm{kg}$ & & & $3.55( \pm 0.77) \times 10^{4}$ \\
\hline Coolant ${ }^{\mathrm{c}}$ for vessel air conditioning & $\mathrm{kg}$ & & & $6.96( \pm 0.07) \times 10^{-1}$ \\
\hline $\begin{array}{l}\text { Coolant }{ }^{\mathrm{c}} \text { for temperature-controlled } \\
\text { container }\end{array}$ & $\mathrm{kg}$ & & & $2.67( \pm 0.60) \times 10^{1}$ \\
\hline \multicolumn{5}{|l|}{ Transportation to retail stores } \\
\hline $\mathrm{ULSD}^{\mathrm{b}}$ for truck main engine & $\mathrm{kg}$ & $9.62( \pm 2.90) \times 10^{6}$ & $3.60( \pm 0.32) \times 10^{5}$ & $2.43( \pm 0.55) \times 10^{6}$ \\
\hline ULSD $^{\mathrm{b}}$ for temperature-controlled container & $\mathrm{kg}$ & $1.471( \pm 0.43) \times 10^{4}$ & $5.49( \pm 0.48) \times 10^{4}$ & $1.85( \pm 0.28) \times 10^{5}$ \\
\hline $\begin{array}{l}\text { Coolant }{ }^{\mathrm{c}} \text { for temperature-controlled } \\
\text { container }\end{array}$ & $\mathrm{kg}$ & $6.08( \pm 1.80)$ & $2.27( \pm 0.19)$ & $5.13( \pm 1.15)$ \\
\hline \multicolumn{5}{|c|}{$\begin{array}{l}{ }^{a} \text { Mean (and standard deviation). The variation/error was propagated for mass of the pollock catch by the AFA fleet, fraction } \\
\text { at-sea fillets of total pollock fillets (processed by catcher-processors and processed on-shore), fraction of at-sea surimi of tota } \\
\text { pollock surimi (processed by catcher-processors and processed on-shore), and mass of fillets to top markets. }{ }^{b} \text { Ultra-low sulfu } \\
\text { diesel (ULSD). } \\
{ }^{c} \text { Refrigerant R-404a as coolant. }\end{array}$} \\
\hline
\end{tabular}


Table S15. Transportation inputs for crab-flavored sticks for three different retail markets

\begin{tabular}{|c|c|c|c|c|}
\hline Description & Units & Japan $^{\text {a }}$ & South Korea $^{a}$ & United States $^{\text {a }}$ \\
\hline \multicolumn{5}{|l|}{ Transportation to retail distribution center } \\
\hline Crab-flavored sticks & $\mathrm{kg}$ & $4.80( \pm 0.76) \times 10^{7}$ & $3.86( \pm 0.55) \times 10^{7}$ & $1.11( \pm 0.37) \times 10^{7}$ \\
\hline Packaging & $\mathrm{kg}$ & $3.83( \pm 0.61) \times 10^{6}$ & $3.08( \pm 0.44) \times 10^{6}$ & $8.83( \pm 2.93) \times 10^{5}$ \\
\hline Pallets & $\mathrm{kg}$ & $8.07( \pm 1.19) \times 10^{5}$ & $6.50( \pm 0.86) \times 10^{5}$ & $1.86( \pm 0.58) \times 10^{5}$ \\
\hline Container & $\mathrm{kg}$ & $4.78( \pm 0.71) \times 10^{6}$ & $3.85( \pm 0.51) \times 10^{6}$ & $1.10( \pm 0.34) \times 10^{6}$ \\
\hline Gross shipping mass & $\mathrm{kg}$ & $5.74( \pm 0.90) \times 10^{7}$ & $4.62( \pm 0.65) \times 10^{7}$ & $1.32( \pm 0.44) \times 10^{7}$ \\
\hline \multicolumn{5}{|l|}{ Heavy-duty truck transportation } \\
\hline $\mathrm{ULSD}^{\mathrm{b}}$ for truck main engine & $\mathrm{kg}$ & $6.58( \pm 0.97) \times 10^{5}$ & $4.08( \pm 0.87) \times 10^{5}$ & \\
\hline ULSD $^{\mathrm{b}}$ for temperature-controlled container & $\mathrm{kg}$ & $5.01( \pm 0.74) \times 10^{4}$ & $3.11( \pm 0.41) \times 10^{4}$ & \\
\hline \multicolumn{5}{|l|}{ Container ship transportation } \\
\hline $\mathrm{HFO}^{\mathrm{d}}$ for ship main and auxiliary engines & & & & $9.00( \pm 2.79) \times 10^{4}$ \\
\hline $\mathrm{HFO}^{\mathrm{d}}$ for temperature-controlled container & & & & $1.86( \pm 0.53) \times 10^{4}$ \\
\hline $\mathrm{MGO}^{\mathrm{e}}$ for ship main and auxiliary engines & $\mathrm{kg}$ & & & $5.93( \pm 1.59) \times 10^{4}$ \\
\hline $\mathrm{MGO}^{\mathrm{e}}$ for temperature-controlled container & $\mathrm{kg}$ & & & $1.13( \pm 0.30) \times 10^{4}$ \\
\hline Coolant ${ }^{\mathrm{c}}$ for vessel air conditioning & $\mathrm{kg}$ & & & $6.96( \pm 010) \times 10^{-1}$ \\
\hline Coolant ${ }^{\mathrm{c}}$ for temperature-controlled container & $\mathrm{kg}$ & & & $7.69( \pm 2.38)$ \\
\hline \multicolumn{5}{|l|}{ Transportation to retail stores } \\
\hline $\mathrm{ULSD}^{\mathrm{b}}$ for truck main engine & $\mathrm{kg}$ & $6.58( \pm 0.97) \times 10^{5}$ & $4.08( \pm 0.87) \times 10^{5}$ & $7.00( \pm 2.31) \times 10^{5}$ \\
\hline ULSD $^{\mathrm{b}}$ for temperature-controlled container & $\mathrm{kg}$ & $5.01( \pm 0.74) \times 10^{4}$ & $3.11( \pm 0.41) \times 10^{4}$ & $5.33( \pm 1.65) \times 10^{4}$ \\
\hline Coolant ${ }^{\mathrm{c}}$ for temperature-controlled container & $\mathrm{kg}$ & $4.16( \pm 0.61)$ & $1.29( \pm 0.31)$ & $1.48( \pm 0.46)$ \\
\hline \multicolumn{5}{|c|}{$\begin{array}{l}\text { a Mean (and standard deviation). The variation/error was propagated for mass of the pollock catch by the AFA fleet, fraction o } \\
\text { at-sea fillets of total pollock fillets (processed by catcher-processors and processed on-shore), fraction of at-sea surimi of total } \\
\text { pollock surimi (processed by catcher-processors and processed on-shore), and mass of surimi to top markets. } \\
{ }^{b} \text { Ultra-low sulfur diesel (ULSD). } \\
{ }^{\mathrm{c}} \text { Refrigerant R-404a as coolant. } \\
{ }^{\mathrm{d}} \text { Heavy fuel oil (HFO). } \\
\text { e Marine gas oil (MGO). }\end{array}$} \\
\hline
\end{tabular}




\section{Table S16. Sources and methods of non-ingredient emission factors}

\begin{tabular}{|c|c|c|c|}
\hline Inventory Item & $\begin{array}{l}\text { Input and Output Data } \\
\text { Source }\end{array}$ & Source inventory name & Emission Factor Source \\
\hline $\mathrm{ULSD}^{\mathrm{a}}$ & $\begin{array}{l}\text { Brandt et al., (2015); Duffy } \\
\text { (2015); PRELIM }{ }^{\text {b }}\end{array}$ & 'Crude oil' and 'ULSD' & Brandt et al., (2015); Duffy (2015); PRELIM; GREET ${ }^{\mathrm{c}}$ \\
\hline $\mathrm{MGO}^{\mathrm{d}}$ & $\begin{array}{l}\text { COWI et al. (2014); } \\
\text { Brandt et al. (2015); Duffy } \\
\text { (2015); PRELIM }\end{array}$ & 'Crude oil' and 'Fuel oil' & COWI et al. (2014); Brandt et al. (2015); Duffy (2015); PRELIM; GREET \\
\hline $\mathrm{HFO}^{\mathrm{e}}$ & $\begin{array}{l}\text { Brandt et al. (2015); Duffy } \\
\text { (2015); PRELIM }\end{array}$ & 'Crude oil' and 'Bunker fuel' & PRELIM, GREET \\
\hline Lubricant oil & GREET & 'Engine oil' & GREET \\
\hline $\mathrm{R}-134 \mathrm{a}$ & Ecoinvent $\mathrm{f,g}$ & 'Refrigerant R134a, at plant/RER U' & Ecoinvent $^{\mathrm{h}}$, Cai et al. (2014) ${ }^{\mathrm{i}}$ \\
\hline$R-404 a^{j}$ & Bovea et al. (2007) & 'R-404A' & Ecoinvent $^{\mathrm{h}}$, Cai et al. (2014) ${ }^{\mathrm{i}}$ \\
\hline Steel & GREET & 'Average steel' & GREET \\
\hline Copper wire & GREET & 'Copper wire' & GREET \\
\hline Aluminum & GREET & 'Average cast aluminum' & GREET \\
\hline Cast iron & GREET & 'Final iron product (combined)' & GREET \\
\hline Chrome & Ecoinvent & 'Chromium steel 18/8, at plant/RER U' & GREET \\
\hline Anti-fouling paint ${ }^{\mathrm{k}}$ & Ecoinvent & $\begin{array}{l}\text { 'Copper oxide, at plant/RER U' and 'Alkyd } \\
\text { resin, long oil, } 70 \% \text { in white spirit, at } \\
\text { plant/RER U' }\end{array}$ & GREET \\
\hline Primer paint & GREET & 'Liquid epoxy resin' & GREET \\
\hline Polyurethane paint & GREET & 'Polyurethane flexible foam' & GREET \\
\hline Enamel paint & Ecoinvent & $\begin{array}{l}\text { 'Alkyd paint, white, } 60 \% \text { in solvent, at } \\
\text { plant/RER U' }\end{array}$ & GREET \\
\hline Nylon & GREET & 'Nylon 6 E' & GREET \\
\hline Lead & GREET & $\begin{array}{l}\text { 'Mix: average lead'; } 73 \% \text { recycled and 27\% } \\
\text { virgin' }\end{array}$ & GREET \\
\hline Polyethylene & GREET & 'Polyethylene terephthalate resin' & GREET \\
\hline Poly-steel & GREET & 'High-impact polystyrene resin' & GREET \\
\hline Polypropylene & GREET & 'Final polypropylene product: combined' & GREET \\
\hline Plastic bag & Ecoinvent & 'Packaging film, LDPE, at plant/RER U' & GREET \\
\hline Liner $^{1}$ & Ecoinvent; Fulton (2010) & $\begin{array}{l}\text { 'Kraft paper, unbleached, at plant/RER S' and } \\
\text { 'Paraffin, at plant/RER U' }\end{array}$ & GREET \\
\hline Cardboard/carton & Ecoinvent & $\begin{array}{l}\text { 'Packaging, corrugated board, mixed fibre, } \\
\text { single wall, at plant/CH U' }\end{array}$ & GREET \\
\hline
\end{tabular}




\begin{tabular}{llll}
$\begin{array}{l}\text { Retractable } \\
\text { polyolefin }\end{array}$ & GREET & 'Adhesives fabrication' & GREET \\
Ammonia & GREET & 'Ammonia production' & GREET \\
$\begin{array}{l}\text { Detergents } \\
\text { Bleach }\end{array}$ & Ecoinvent & 'Soap, at plant/RER U' & GREET \\
Caustic soda & Ecoinvent & $\begin{array}{l}\text { 'Sodium hypochlorite, 15\% in H2O, at } \\
\text { plant/RER U' }\end{array}$ & GREET \\
\hline
\end{tabular}

${ }^{a}$ Ultra-low sulfur diesel with 0.0015 (\% wt.) fuel sulfur.

${ }^{\mathrm{b}}$ The Petroleum Refinery Life Cycle Inventory Model (PRELIM) v.1.1 (Abella et al., 2012)

${ }^{c}$ The Greenhouse Gases, Regulated Emissions, and Energy Use in Transportation (GREET) Model, Argonne National Lab v.1.3.0.12842.

${ }^{\mathrm{d}}$ Marine gas oil with 0.1 (\% wt.) fuel sulfur.

${ }^{\mathrm{e}}$ Heavy fuel oil with 2.6 (\% wt.) fuel sulfur.

${ }^{\mathrm{f}}$ Database inputs obtained from Simapro v. 7.2.

${ }^{g}$ Ecoinvent database v. 2.2.

${ }^{\mathrm{h}}$ IPCC 2007 GWP 100a 1.02 method used to obtain inventory of emissions for $\mathrm{CO}_{2}, \mathrm{CH}_{4}, \mathrm{~N}_{2} \mathrm{O}$, NOx, SOx, and PM2.5.

${ }^{\mathrm{i}}$ Emissions for black carbon (BC) and organic carbon (BC) estimated as a fraction of PM2.5 emissions; natural gas boiler (Conf. Table $14 ; 0.165 \mathrm{~g}$ BC $\mathrm{g}$ PM2.5 ${ }^{-1}$ and $0.428 \mathrm{~g}$ OC $\mathrm{g}$ PM2.5 $5^{-1}$.

${ }^{\mathrm{j}}$ Data for R-404a was unavailable; following (Bovea et al., 2007) an incremental increase of 1.6 applied to R-134a emissions.

${ }^{\mathrm{k}}$ Ingredient list based on an anti-fouling bottom paint for steel hulls with a formula of $45 \%$ copper oxide and $55 \%$ inert materials; for the inert materials 'Alkyd resin, long oil, $70 \%$ in white spirit, at plant/RER U' were assumed.

${ }^{1}$ Following Fulton (2010), the composition of the liner is $83 \%$ kraft paper and $17 \%$ paraffin. 


\section{Table S17. Sources and methods of non-ingredient emission factors}

\begin{tabular}{|c|c|c|c|}
\hline Inventory Item & Input and Output Data Source & Source inventory name & $\begin{array}{l}\text { Emission } \\
\text { Factor Source }\end{array}$ \\
\hline Wheat-mix batter & Ecoinvent $^{\mathrm{a}, \mathrm{b}}$; Vázquez-Rowe et al. (2013) & 'Wheat-mix batter' & GREET $^{\mathrm{c}}$ \\
\hline Tap water & Ecoinvent & 'Tap water, at user/RER U' & GREET \\
\hline Breadcrumbs & Ecoinvent; Vázquez-Rowe et al. (2013) & 'Breadcrumbs' & GREET \\
\hline Wheat starch ${ }^{\mathrm{d}}$ & Ecoinvent; Narayanaswamy et al. (2003) & 'Wheat starch' & GREET \\
\hline Potato starch & Ecoinvent & 'Potato starch, at plant/DE U' & GREET \\
\hline Sugar & Ecoinvent & 'Sugar, from sugar cane, at sugar refinery/CH U' & GREET \\
\hline Salt & GREET & 'Sodium chloride' & GREET \\
\hline Crab extract & USA Input Output Database $98^{\text {a,e }}$ & 'Flavoring extracts and flavoring syrups, n.e.c.' and 'crab extract' ${ }^{f}$ & GREET \\
\hline Crab flavoring & USA Input Output Database 98 & 'Flavoring extracts and flavoring syrups, n.e.c.' and 'crab flavoring' g & GREET \\
\hline Carrageenan & USA Input Output Database 98 & 'Flavoring extracts and flavoring syrups, n.e.c.' and 'carrageenan extract' h & GREET \\
\hline Kelp extract & USA Input Output Database 98 & 'Flavoring extracts and flavoring syrups, n.e.c.' and 'kelp extract' ${ }^{\mathrm{i}}$ & GREET \\
\hline Albumen & LCA Food DK Database ${ }^{a}$ & 'Egg' j & GREET \\
\hline Calcium carbonate & GREET & 'Calcium carbonate production' & GREET \\
\hline Soybean oil & GREET & 'Soy oil from soybeans (unallocated)' & GREET \\
\hline Phosphate & GREET & 'Phosphate (P2O5) from MAP and DAP' & GREET \\
\hline Seasoning mix & USA Input Output Database $98^{\mathrm{j}}$ & 'Flavoring extracts and flavoring syrups, n.e.c.' and 'MSG' k & GREET \\
\hline Red colorant & USA Input Output Database 98 & 'Flavoring extracts and flavoring syrups, n.e.c.' and 'red food coloring' ${ }^{1}$ & GREET \\
\hline Distilled water & Ecoinvent & 'Water, deionised, at plant/CH U' & GREET \\
\hline Sunflower oil ${ }^{\mathrm{m}}$ & Ecoinvent; Schmidt (2015) & 'Sunflower oil' & GREET \\
\hline \multicolumn{4}{|c|}{${ }^{\mathrm{a}}$ Database inputs obtained from Simapro v. 7.2. } \\
\hline \multicolumn{4}{|c|}{${ }^{\mathrm{b}}$ Ecoinvent database v. 2.2. } \\
\hline \multirow{2}{*}{\multicolumn{4}{|c|}{$\begin{array}{l}\text { d Wheat starch inputs obtained from (Narayanaswamy et al., 2003); } 1.34 \text { kg wheat flour per kg wheat starch; wheat flour inputs obtained from Ecoinvent v.2.2 database. } \\
\text { e Non-renewable fossil energy per US Dollar (USD) inputs obtained from process contributions with indicator 'characterization' selected and method 'Cumulative Energy Demand' } \\
\text { v.1.07. }\end{array}$}} \\
\hline & & & \\
\hline \multicolumn{4}{|c|}{${ }^{\mathrm{f}}$ Crab extract costs obtained from Alibaba $(\mathrm{n}=3)$; mean and standard deviation price for $1 \mathrm{~kg}$ crab extract: $\$ 1.6( \pm 0.4)$ USD. } \\
\hline \multicolumn{4}{|c|}{${ }^{\mathrm{g}}$ Crab flavoring costs obtained from Alibaba $(\mathrm{n}=5)$; mean and standard deviation price for $1 \mathrm{~kg}$ seafood flavoring: $\$ 0.8( \pm 0.4)$ USD. } \\
\hline \multicolumn{4}{|c|}{${ }^{\mathrm{h}}$ Carrageenan costs obtained from Alibaba $(\mathrm{n}=5)$; mean and standard deviation price for 1 kg carrageenan: $\$ 1( \pm 0.9)$ USD. } \\
\hline \multicolumn{4}{|c|}{ i Kelp extract costs obtained from Alibaba $(\mathrm{n}=6)$; mean and standard deviation price for $1 \mathrm{~kg}$ kelp extract: $\$ 1.1( \pm 0.7)$ USD. } \\
\hline \multicolumn{4}{|c|}{$\begin{array}{l}\mathrm{j} 89 \% \text { of emissions allocated to egg with remainder allocated to spent laying hens; egg whites make up about } 66 \% \text { of the liquid weight: www.ncegg.org/egg-nutrition-center/yolks- } \\
\text { vs-whites/. }\end{array}$} \\
\hline
\end{tabular}


${ }^{\mathrm{m}}$ Sunflower oil inputs obtained from Schmidt (2015); 'Sunflower IP, at farm/CH U' inputs obtained from Ecoinvent v.2.2 database. 
Table S18. Sources and methods of alternate non-ingredient emission factors

\begin{tabular}{|c|c|c|c|}
\hline Inventory Item & Input and Output Data Source $^{a}$ & Source inventory name & Emission Factor Source ${ }^{b, c}$ \\
\hline Lubricant oil & Ecoinvent $^{\mathrm{d}}$ & 'Lubricating oil, at plant/RER U' & Ecoinvent; Cai et al. (2014) ${ }^{\mathrm{e}}$ \\
\hline Steel & Ecoinvent & 'Steel product manufacturing, average metal working/RER U' & Ecoinvent; Cai et al. (2014) \\
\hline Copper wire & Ecoinvent & 'Copper product manufacturing, average metal working/RER U' & Ecoinvent; Cai et al. (2014) \\
\hline Aluminum & Ecoinvent & 'Aluminum, secondary, shape casted/RNA' & Ecoinvent; Cai et al. (2014) \\
\hline Cast iron & Ecoinvent & 'Cast iron, at plant/RER U' & Ecoinvent; Cai et al. (2014) \\
\hline Chrome & Ecoinvent & $\begin{array}{l}\text { 'Chromium steel product manufacturing, average metal } \\
\text { working/RER U' }\end{array}$ & Ecoinvent; Cai et al. (2014) \\
\hline Anti-fouling paint ${ }^{\mathrm{f}}$ & Ecoinvent & $\begin{array}{l}\text { 'Copper oxide, at plant/RER U' and 'Alkyd resin, long oil, } 70 \% \text { in } \\
\text { white spirit, at plant/RER U' }\end{array}$ & Ecoinvent; Cai et al. (2014) \\
\hline Primer paint & Industry data 2.0 database & Liquid epoxy resins E' & Industry data 2.0 database; Cai et al., (2014) \\
\hline Polyurethane paint & Ecoinvent & 'Polyurethane, flexible foam, at plant/RER U' & Ecoinvent; Cai et al. (2014) \\
\hline Enamel paint & Ecoinvent & 'Alkyd paint, white, $60 \%$ in solvent, at plant/RER U' & Ecoinvent; Cai et al. (2014) \\
\hline Nylon & Ecoinvent & 'Nylon 6 at plant/RER U' & Ecoinvent; Cai et al. (2014) \\
\hline Lead & Ecoinvent & 'Lead, from combined metal production, at refinery/SE U' & Ecoinvent; Cai et al. (2014) \\
\hline Polyethylene & Ecoinvent & 'Polethylene terephthalate resin, at plant/kg/RNA' & Ecoinvent; Cai et al. (2014) \\
\hline Poly-steel & Ecoinvent & 'High impact polystyrene resin, at plant/RNA' & Ecoinvent; Cai et al. (2014) \\
\hline Polypropylene & Ecoinvent & 'Polypropylene resin, at plant/RNA' & Ecoinvent; Cai et al. (2014) \\
\hline Plastic bag & Ecoinvent & Packaging film, LDPE, at plant/RER U' & Ecoinvent; Cai et al. (2014) \\
\hline Liner $^{g}$ & Ecoinvent & $\begin{array}{l}\text { 'Kraft paper, unbleached, at plant/RER S' and 'Paraffin, at } \\
\text { plant/RER U' }\end{array}$ & Ecoinvent; Cai et al. (2014) \\
\hline Cardboard/carton & Ecoinvent & $\begin{array}{l}\text { 'Packaging, corrugated board, mixed fibre, single wall, at plant/CH } \\
\text { U' }\end{array}$ & Ecoinvent; Cai et al. (2014) \\
\hline Retractable polyolefin & Ecoinvent & Packaging film, LDPE, at plant/RER U' & Ecoinvent; Cai et al. (2014) \\
\hline Ammonia & Ecoinvent & 'Ammonia, liquid, at regional storehouse/RER U' & Ecoinvent; Cai et al. (2014) \\
\hline Detergents & Ecoinvent & 'Soap, at plant/RER U' & Ecoinvent; Cai et al. (2014) \\
\hline Bleach & Ecoinvent & 'Sodium hypochlorite, $15 \%$ in $\mathrm{H} 2 \mathrm{O}$, at plant/RER U' & Ecoinvent; Cai et al. (2014) \\
\hline Caustic soda & Ecoinvent & 'Sodium hydroxide, $50 \%$ in $\mathrm{H} 2 \mathrm{O}$, production mix, at plant/RER U' & Ecoinvent; Cai et al. (2014) \\
\hline
\end{tabular}


${ }^{e}$ Black carbon and organic carbon emissions estimated by mass fractions PM2.5 emissions by primary energy sources (conf. Table 14).

${ }^{\mathrm{f}}$ Ingredient list based on an anti-fouling bottom paint for steel hulls with a formula of $45 \%$ copper oxide and 55\% inert materials; for the inert materials 'Alkyd resin, long oil, $70 \%$ in white spirit, at plant/RER U' were assumed.

${ }^{\mathrm{g}}$ Following Fulton (2010), the composition of the liner is $83 \%$ kraft paper and $17 \%$ paraffin. 
Table S19. Sources and methods of alternate non-ingredient emission factors

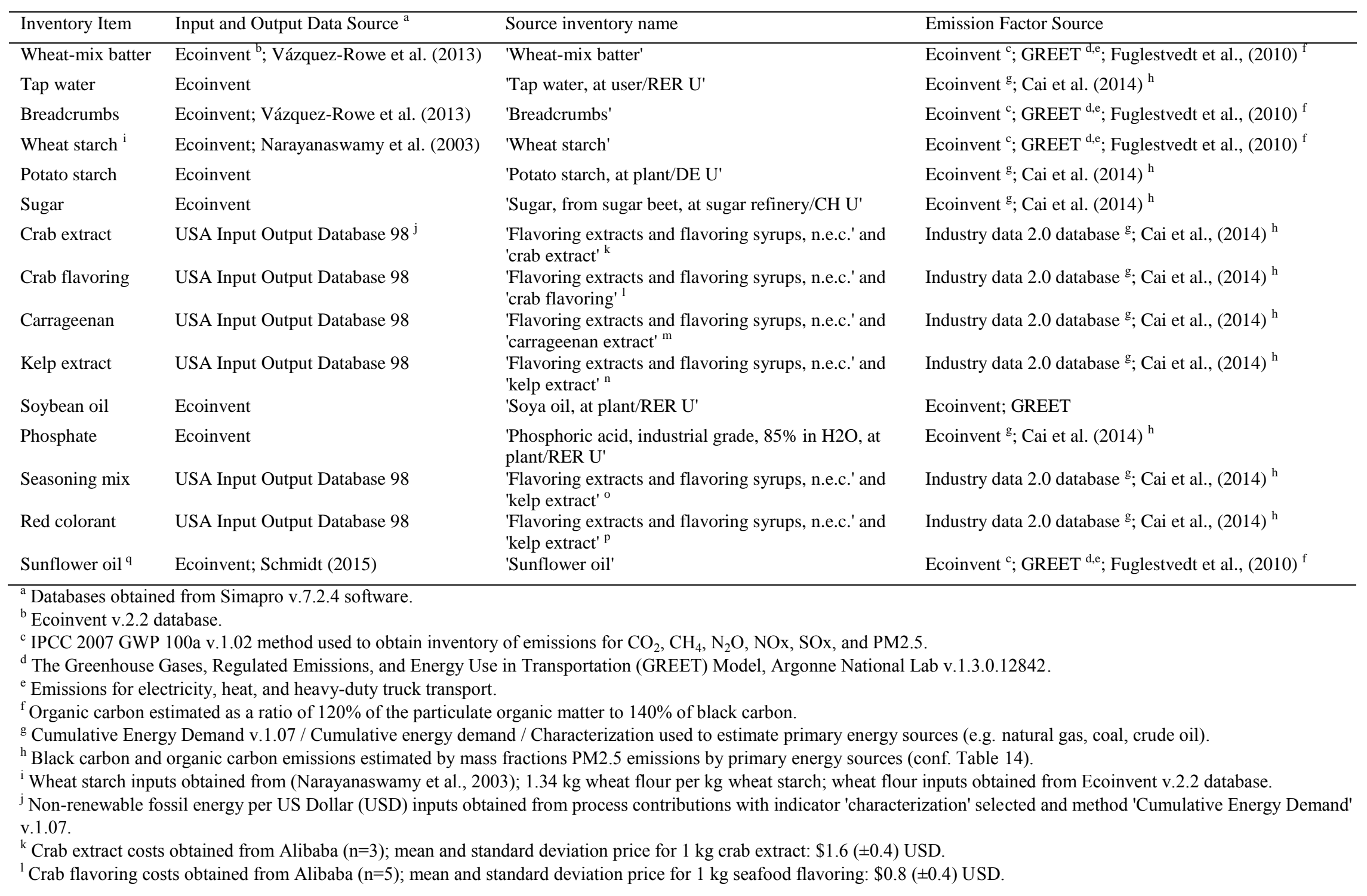


${ }^{\mathrm{m}}$ Carageenan costs obtained from Alibaba $(\mathrm{n}=5)$; mean and standard deviation price for $1 \mathrm{~kg}$ carageenan: $\$ 1( \pm 0.9)$ USD

${ }^{\mathrm{n}}$ Kelp extract costs obtained from Alibaba $(\mathrm{n}=6)$; mean and standard deviation price for $1 \mathrm{~kg}$ kelp extract: $\$ 1.1( \pm 0.7)$ USD.

${ }^{\circ}$ Monosodium glutamate (MSG) costs obtained from Alibaba $(n=11)$; mean and standard deviation price for 1 kg MSG: \$0.8 ( \pm 0.4$)$ USD.

${ }^{\mathrm{p}}$ Red colorant costs obtained from Alibaba $(\mathrm{n}=3)$; mean and standard deviation for $1 \mathrm{~kg}$ red colorant: \$1 ( \pm 0.4$)$ USD.

${ }^{q}$ Sunflower oil inputs obtained from Schmidt (2015); 'Sunflower IP, at farm/CH U' inputs obtained from Ecoinvent v.2.2 database. 
Table S20. Fishing vessel emission factors for long-lived climate forcing pollutants

\begin{tabular}{lllllll}
\hline \multirow{2}{*}{ Fuel type } & $\begin{array}{l}\text { Fuel sulfur } \\
\text { (\% wt.) }\end{array}$ & \multicolumn{5}{c}{ Emission factor pollutants ${ }^{\mathrm{a}}\left(\mathrm{g} \mathrm{kg} \mathrm{fuel}{ }^{-1}\right)$} \\
\cline { 3 - 6 } & $\mathrm{CO}_{2}$ & $\mathrm{CH}_{4}$ & $\mathrm{~N}_{2} \mathrm{O}$ & $\mathrm{NOx}^{\mathrm{b}}$ & $\mathrm{SO}_{\mathrm{x}}{ }^{\mathrm{c}}$ \\
\hline $\mathrm{ULSD}^{\mathrm{d}}$ & 0.0015 & 3,183 & 0.03 & 0.16 & 52 & 0.03 \\
$\mathrm{MGO}^{\mathrm{e}}$ & 0.1 & 3,183 & 0.02 & 0.15 & 52 & 1.96 \\
\hline
\end{tabular}

${ }^{a}$ Source: (ICF International, 2009).

${ }^{\mathrm{b}} \mathrm{NOx}$ given as nitrogen dioxide $\left(\mathrm{NO}_{2}\right)$.

${ }^{\mathrm{c}} \mathrm{SOx}$ given as sulfur dioxide $\left(\mathrm{SO}_{2}\right)$.

${ }^{\mathrm{d}}$ Ultra-low sulfur diesel (ULSD).

${ }^{\mathrm{e}}$ Marine gas oil (MGO). 
Table S21. Emission factors of black carbon and organic carbon pollutants as a function of engine speed

\begin{tabular}{lll}
\hline & \multicolumn{2}{l}{ Emission factor pollutants $\left(\mathrm{g} \mathrm{kg} \mathrm{fuel}^{-1}\right)$} \\
\cline { 2 - 3 } Engine type & $\mathrm{BC}^{\mathrm{a}, \mathrm{b}}$ & $\mathrm{OC}^{\mathrm{a}, \mathrm{c}, \mathrm{d}}$ \\
\hline SSD $^{\mathrm{e}, \mathrm{f}}$ & $0.41( \pm 0.27)$ & $0.48( \pm 0.32)$ \\
MSD $^{\mathrm{f}, \mathrm{g}}$ & $0.85( \pm 0.14)$ & $0.99( \pm 0.16)$ \\
HSD $^{\mathrm{f}, \mathrm{h}}$ & $0.48( \pm 0.16)$ & $0.56( \pm 0.18)$ \\
\hline
\end{tabular}

${ }^{\mathrm{a}}$ Mean (and 95\% confidence intervals).

${ }^{\mathrm{b}}$ Black carbon $(\mathrm{BC})$.

${ }^{\mathrm{c}}$ Organic carbon (OC).

${ }^{\mathrm{d}}$ OC emission factor estimates are a function of the ratio of particulate organic matter to BC (Petzold et al., 2011; Fuglestvedt et al., 2010).

${ }^{\mathrm{e}}$ Slow speed diesel (SSD).

${ }^{\mathrm{f}}$ Emission factor estimates from plume-sampling studies (Lack et al., 2008; Petzold et al., 2011; Buffaloe et al., 2014; Cappa et al., 2014).

${ }^{\mathrm{g}}$ Medium speed diesel (MSD).

${ }^{\mathrm{h}}$ High speed diesel (HSD). 
Table S22. Container ship emission factors by trip segment and fuel type

\begin{tabular}{llllllll}
\hline Trip segment & $\mathrm{CO}_{2}$ & $\mathrm{CH}_{4}$ & $\mathrm{~N}_{2} \mathrm{O}$ & $\mathrm{NOx}^{\mathrm{a}}$ & $\mathrm{SOx}^{\mathrm{b}}$ & $\mathrm{BC}$ & $\mathrm{OC}$ \\
\hline RSZ $^{\mathrm{c}, \mathrm{d}, \mathrm{e}}$ & & & & & & \\
$\mathrm{HFO}^{\mathrm{f}}$ & $4.47 \times 10^{-3}$ & $9.81 \times 10^{-8}$ & $2.13 \times 10^{-7}$ & $1.08 \times 10^{-4}$ & $7.60 \times 10^{-5}$ & $5.77 \times 10^{-7}$ & $6.76 \times 10^{-7}$ \\
$\mathrm{MGO}^{\mathrm{g}}$ & $4.47 \times 10^{-3}$ & $9.81 \times 10^{-8}$ & $2.13 \times 10^{-7}$ & $1.08 \times 10^{-4}$ & $3.34 \times 10^{-6}$ & $5.77 \times 10^{-7}$ & $6.76 \times 10^{-7}$ \\
Cruise $^{\mathrm{d}, \mathrm{e}, \mathrm{h}}$ & & & & & & \\
$\mathrm{HFO}^{\mathrm{f}}$ & $1.11 \times 10^{-2}$ & $1.05 \times 10^{-7}$ & $5.52 \times 10^{-7}$ & $2.85 \times 10^{-4}$ & $1.90 \times 10^{-4}$ & $1.44 \times 10^{-6}$ & $1.69 \times 10^{-6}$ \\
$\mathrm{MGO}^{\mathrm{g}}$ & $1.11 \times 10^{-2}$ & $1.05 \times 10^{-7}$ & $5.52 \times 10^{-7}$ & $2.85 \times 10^{-4}$ & $3.34 \times 10^{-6}$ & $1.44 \times 10^{-6}$ & $1.69 \times 10^{-6}$ \\
Hotel $^{\mathrm{e}, \mathrm{i}, \mathrm{j}}$ & & & & & & \\
$\mathrm{HFO}^{\mathrm{f},}$ & $1.19 \times 10^{3}$ & $6.62 \times 10^{-3}$ & $5.13 \times 10^{-2}$ & $2.43 \times 10^{1}$ & $2.02 \times 10^{1}$ & $1.54 \times 10^{-1}$ & $1.80 \times 10^{-1}$ \\
$\mathrm{MGO}^{\mathrm{g}}$ & $1.19 \times 10^{3}$ & $6.62 \times 10^{-3}$ & $5.13 \times 10^{-2}$ & $2.43 \times 10^{1}$ & $9.77 \times 10^{-1}$ & $1.54 \times 10^{-1}$ & $1.80 \times 10^{-1}$ \\
\hline
\end{tabular}

${ }^{\mathrm{a}} \mathrm{NOx}$ as nitrogen dioxide $\left(\mathrm{NO}_{2}\right)$.

${ }^{\mathrm{b}} \mathrm{SOx}$ as sulfur dioxide $\left(\mathrm{SO}_{2}\right)$.

${ }^{\mathrm{c}}$ Reduced speed zone (RSZ); container ship speed $19.4 \mathrm{~km} \mathrm{~h}^{-1}$ (10.5 knots) and a load factor (LF) of 0.10.

${ }^{\mathrm{d}}$ Emission factor given in units $\mathrm{kg}$ of pollutant per ton-kilometer.

${ }^{\mathrm{e}}$ Source: The Greenhouse Gases, Regulated Emissions, and Energy Use in Transportation (GREET) Model, Argonne National Lab v.1.3.0.12842 Marine plug-in module (Wang, 2011).

${ }^{\mathrm{f}}$ Heavy fuel oil (HFO) with a fuel sulfur level of 2.4 ( $\% \mathrm{wt}$.).

${ }^{\mathrm{g}}$ Marine gas oil (MGO) with a fuel sulfur level of 0.1 (\% wt.).

${ }^{\mathrm{h}}$ Cruise zone; container ship speed $36.1 \mathrm{~km} \mathrm{~h}^{-1}$ (19.5 knots) and a LF of 0.65 .

${ }^{\mathrm{i}}$ Emission factor given in units $\mathrm{kg}$ of pollutant per hour.

${ }^{\mathrm{j}}$ Auxiliary engine LF of 0.20 . 
Table S23. Heavy-duty truck emission factors

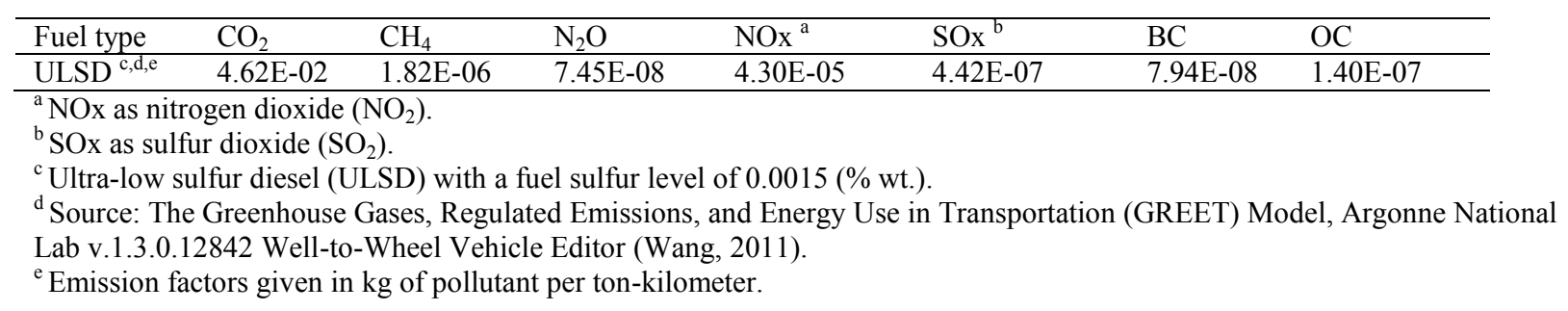


Table S24. Indirect emission factors of non-ingredient materials and fuels

\begin{tabular}{|c|c|c|c|c|c|c|c|c|c|c|c|}
\hline $\begin{array}{l}\text { Inventory Item } \\
(1 \mathrm{~kg})\end{array}$ & $\begin{array}{l}\mathrm{CO}_{2} \\
(\mathrm{~kg})\end{array}$ & $\begin{array}{l}\mathrm{CH}_{4} \\
(\mathrm{~kg})\end{array}$ & $\begin{array}{l}\mathrm{N}_{2} \mathrm{O} \\
(\mathrm{kg})\end{array}$ & $\begin{array}{l}\text { NOx } \\
(\mathrm{kg})\end{array}$ & $\begin{array}{l}\text { SOx } \\
(\mathrm{kg})\end{array}$ & $\begin{array}{l}\mathrm{BC} \\
(\mathrm{kg})\end{array}$ & $\begin{array}{l}\text { POC } \\
(\mathrm{kg})\end{array}$ & $\begin{array}{l}\text { CFC-12 } \\
(\mathrm{kg})\end{array}$ & $\begin{array}{l}\text { CFC-113 } \\
(\mathrm{kg})\end{array}$ & $\begin{array}{l}\text { HFC-124 } \\
(\mathrm{kg})\end{array}$ & $\begin{array}{l}\text { HFC-134a } \\
(\mathrm{kg})\end{array}$ \\
\hline $\operatorname{ULSD}^{\mathrm{a}, \mathrm{b}}$ & $6.91 \mathrm{E}-01$ & $6.49 \mathrm{E}-03$ & $9.88 \mathrm{E}-06$ & $1.78 \mathrm{E}-03$ & $9.15 \mathrm{E}-04$ & $1.62 \mathrm{E}-05$ & $3.32 \mathrm{E}-05$ & & & & \\
\hline $\mathrm{MGO}^{\mathrm{b}, \mathrm{c}}$ & $6.27 \mathrm{E}-01$ & $6.86 \mathrm{E}-03$ & 8.89E-06 & $1.77 \mathrm{E}-03$ & 8.78E-04 & $1.62 \mathrm{E}-05$ & 3.31E-05 & & & & \\
\hline $\mathrm{HFO}^{\mathrm{b}, \mathrm{d}}$ & $2.92 \mathrm{E}-01$ & $5.7 \mathrm{E}-03$ & $3.4 \mathrm{E}-06$ & $1.3 \mathrm{E}-03$ & $6.6 \mathrm{E}-04$ & $1.2 \mathrm{E}-05$ & $2.3 \mathrm{E}-05$ & & & & \\
\hline Lubricant oil & $3.13 \mathrm{E}+00$ & $3.6 \mathrm{E}-03$ & $6.2 \mathrm{E}-05$ & $6.6 \mathrm{E}-03$ & $2.0 \mathrm{E}-02$ & $4.2 \mathrm{E}-05$ & 4.6E-05 & & & & \\
\hline $\mathrm{R}-134 \mathrm{a}$ & $6.20 \mathrm{E}+00$ & $1.6 \mathrm{E}-02$ & $9.6 \mathrm{E}-05$ & $2.7 \mathrm{E}-02$ & $9.4 \mathrm{E}-02$ & $4.9 \mathrm{E}-04$ & $1.3 \mathrm{E}-03$ & $1.6 \mathrm{E}-04$ & $1.0 \mathrm{E}-02$ & $1.0 \mathrm{E}-02$ & $1.9 \mathrm{E}-02$ \\
\hline $\mathrm{R}-404 \mathrm{a}$ & $9.73 \mathrm{E}+00$ & 4.0E-04 & $1.0 \mathrm{E}-04$ & $4.0 \mathrm{E}-02$ & $5.0 \mathrm{E}-02$ & $2.0 \mathrm{E}-04$ & $3.0 \mathrm{E}-04$ & $3.0 \mathrm{E}-04$ & $2.0 \mathrm{E}-02$ & $2.0 \mathrm{E}-02$ & $3.0 \mathrm{E}-02$ \\
\hline Steel & $2.59 \mathrm{E}+00$ & $4.4 \mathrm{E}-03$ & $2.6 \mathrm{E}-05$ & $2.5 \mathrm{E}-03$ & $9.6 \mathrm{E}-03$ & $1.2 \mathrm{E}-05$ & $2.6 \mathrm{E}-05$ & & & & \\
\hline Copper wire & $3.08 \mathrm{E}+00$ & $5.4 \mathrm{E}-03$ & 5.7E-05 & 7.8E-03 & $1.5 \mathrm{E}-01$ & $1.0 \mathrm{E}-04$ & $8.0 \mathrm{E}-05$ & & & & \\
\hline Aluminum & $2.67 \mathrm{E}+00$ & $6.2 \mathrm{E}-03$ & $5.6 \mathrm{E}-05$ & $2.5 \mathrm{E}-03$ & 7.6E-03 & $2.1 \mathrm{E}-05$ & 4.1E-05 & & & & \\
\hline Cast iron & $9.10 \mathrm{E}-01$ & $4.6 \mathrm{E}-03$ & $1.7 \mathrm{E}-05$ & $1.8 \mathrm{E}-03$ & $3.5 \mathrm{E}-03$ & $9.0 \mathrm{E}-06$ & $2.2 \mathrm{E}-04$ & & & & \\
\hline Chrome $^{\mathrm{b}}$ & $5.00 \mathrm{E}+00$ & $8.5 \mathrm{E}-03$ & 4.6E-05 & $4.9 \mathrm{E}-03$ & $2.0 \mathrm{E}-02$ & 2.3E-05 & $4.9 \mathrm{E}-05$ & & & & \\
\hline Anti-fouling paint ${ }^{b}$ & $2.88 \mathrm{E}+00$ & $9.9 \mathrm{E}-03$ & 4.0E-03 & $5.2 \mathrm{E}-03$ & 2.7E-03 & 8.4E-05 & $6.5 \mathrm{E}-05$ & & & & \\
\hline Primer paint & $5.82 \mathrm{E}+00$ & $2.0 \mathrm{E}-02$ & $1.8 \mathrm{E}-04$ & $9.0 \mathrm{E}-03$ & $1.2 \mathrm{E}-02$ & $6.5 \mathrm{E}-05$ & $1.2 \mathrm{E}-04$ & & & & \\
\hline Polyurethane paint & $2.97 \mathrm{E}+00$ & $1.9 \mathrm{E}-02$ & $9.2 \mathrm{E}-05$ & $5.8 \mathrm{E}-03$ & $1.8 \mathrm{E}-02$ & $5.7 \mathrm{E}-05$ & $6.7 \mathrm{E}-05$ & & & & \\
\hline Enamel paint ${ }^{b}$ & $1.86 \mathrm{E}+00$ & 7.9E-03 & $1.3 \mathrm{E}-03$ & $2.5 \mathrm{E}-03$ & $3.3 \mathrm{E}-03$ & $3.7 \mathrm{E}-05$ & $4.1 \mathrm{E}-05$ & & & & \\
\hline Nylon & $6.84 \mathrm{E}+00$ & $2.3 \mathrm{E}-02$ & $9.0 \mathrm{E}-03$ & $1.6 \mathrm{E}-02$ & $1.5 \mathrm{E}-02$ & $6.2 \mathrm{E}-05$ & $1.1 \mathrm{E}-04$ & & & & \\
\hline Lead & $5.20 \mathrm{E}-01$ & $2.5 \mathrm{E}-03$ & $5.1 \mathrm{E}-06$ & 8.2E-04 & $1.3 \mathrm{E}-02$ & $2.4 \mathrm{E}-06$ & $5.8 \mathrm{E}-06$ & & & & \\
\hline Polyethylene & $2.94 \mathrm{E}+00$ & $1.6 \mathrm{E}-02$ & 7.4E-05 & $5.4 \mathrm{E}-03$ & $1.3 \mathrm{E}-02$ & 5.4E-05 & $6.5 \mathrm{E}-05$ & & & & \\
\hline Poly-steel & $2.47 \mathrm{E}+00$ & $2.1 \mathrm{E}-02$ & $8.4 \mathrm{E}-05$ & $4.4 \mathrm{E}-03$ & $1.7 \mathrm{E}-02$ & $3.5 \mathrm{E}-05$ & $5.8 \mathrm{E}-05$ & & & & \\
\hline Polypropylene & $1.83 \mathrm{E}+00$ & $2.5 \mathrm{E}-02$ & 8.7E-05 & $3.7 \mathrm{E}-03$ & $2.4 \mathrm{E}-02$ & $2.5 \mathrm{E}-05$ & 4.3E-05 & & & & \\
\hline Plastic bag ${ }^{b}$ & $2.26 \mathrm{E}+00$ & $2.8 \mathrm{E}-02$ & $1.1 \mathrm{E}-04$ & 3.7E-03 & $2.6 \mathrm{E}-02$ & 2.3E-05 & 4.1E-05 & & & & \\
\hline Liner $^{\mathrm{b}}$ & $7.98 \mathrm{E}-01$ & $1.2 \mathrm{E}-03$ & $1.2 \mathrm{E}-04$ & 2.7E-03 & 2.7E-02 & 2.7E-05 & $6.7 \mathrm{E}-03$ & & & & \\
\hline Cardboard/carton ${ }^{\mathrm{b}}$ & $1.38 \mathrm{E}+00$ & $3.3 \mathrm{E}-03$ & $2.1 \mathrm{E}-05$ & $1.3 \mathrm{E}-03$ & 8.0E-04 & $8.2 \mathrm{E}-06$ & $2.0 \mathrm{E}-05$ & & & & \\
\hline Retractable polyolefin & $3.20 \mathrm{E}+00$ & $2.6 \mathrm{E}-02$ & $2.5 \mathrm{E}-04$ & 5.3E-03 & $1.8 \mathrm{E}-02$ & 4.1E-05 & $6.1 \mathrm{E}-05$ & & & & \\
\hline Ammonia & $2.21 \mathrm{E}+00$ & $9.0 \mathrm{E}-03$ & $4.5 \mathrm{E}-05$ & 2.3E-03 & 8.0E-04 & $1.6 \mathrm{E}-05$ & 3.7E-05 & & & & \\
\hline Detergents ${ }^{b}$ & $8.17 \mathrm{E}-01$ & $2.0 \mathrm{E}-03$ & $1.9 \mathrm{E}-04$ & $1.2 \mathrm{E}-03$ & 7.0E-04 & $1.2 \mathrm{E}-05$ & $1.4 \mathrm{E}-05$ & & & & \\
\hline
\end{tabular}




\begin{tabular}{llllllll} 
Bleach $^{\text {b }}$ & $1.38 \mathrm{E}+00$ & $3.3 \mathrm{E}-03$ & $2.8 \mathrm{E}-05$ & $1.5 \mathrm{E}-03$ & $1.8 \mathrm{E}-03$ & $9.5 \mathrm{E}-06$ & $2.1 \mathrm{E}-05$ \\
Caustic soda & $2.09 \mathrm{E}+00$ & $5.1 \mathrm{E}-03$ & $4.4 \mathrm{E}-05$ & $2.0 \mathrm{E}-03$ & $3.1 \mathrm{E}-03$ & $1.5 \mathrm{E}-05$ & $3.3 \mathrm{E}-05$ \\
\hline
\end{tabular}

${ }^{a}$ Ultra-low sulfur diesel with 0.0015 (\% wt.) fuel sulfur.

${ }^{\mathrm{b}}$ Datasets available at: https://doi.org/10.6071/M3HW93.

${ }^{\mathrm{c}}$ Marine gas oil with 0.1 (\% wt.) fuel sulfur.

${ }^{\mathrm{d}}$ Heavy fuel oil with 2.6 (\% wt.) fuel sulfur. 
Table S25. Regional grid-electricity emission factors

\begin{tabular}{|c|c|c|c|c|c|c|c|}
\hline Country & $\begin{array}{l}\mathrm{CO}_{2} \\
\text { (kg pollutants }\end{array}$ & $\begin{array}{l}\mathrm{CH}_{4} \\
\text { MJ electricity }^{-1} \text { ) }\end{array}$ & $\mathrm{N}_{2} \mathrm{O}$ & $\mathrm{NOx}^{\mathrm{a}}$ & $\mathrm{SOx}^{b}$ & $\mathrm{BC}$ & $\mathrm{OC}$ \\
\hline Germany $^{\mathrm{c}, \mathrm{d}, \mathrm{e}}$ & $1.33 \mathrm{E}-01$ & $2.26 \mathrm{E}-04$ & $3.77 \mathrm{E}-06$ & $1.12 \mathrm{E}-04$ & $3.20 \mathrm{E}-04$ & $2.72 \mathrm{E}-06$ & $6.13 \mathrm{E}-06$ \\
\hline Netherlands ${ }^{\mathrm{c}, \mathrm{d}, \mathrm{e}}$ & $1.58 \mathrm{E}-01$ & $3.22 \mathrm{E}-04$ & $3.47 \mathrm{E}-06$ & $1.55 \mathrm{E}-04$ & $2.98 \mathrm{E}-04$ & $2.23 \mathrm{E}-06$ & 4.93E-06 \\
\hline Japan ${ }^{\mathrm{c}, \mathrm{d}, \mathrm{e}}$ & $1.59 \mathrm{E}-01$ & $3.25 \mathrm{E}-04$ & $3.03 \mathrm{E}-06$ & $1.98 \mathrm{E}-04$ & $3.04 \mathrm{E}-04$ & $1.82 \mathrm{E}-06$ & $3.87 \mathrm{E}-06$ \\
\hline South Korea ${ }^{c, d, e}$ & $1.49 \mathrm{E}-01$ & 2.64E-04 & $2.36 \mathrm{E}-06$ & $1.22 \mathrm{E}-04$ & $3.14 \mathrm{E}-04$ & $7.21 \mathrm{E}-07$ & $1.54 \mathrm{E}-06$ \\
\hline United States $^{\mathrm{f}}$ & $1.40 \mathrm{E}-01$ & $2.40 \mathrm{E}-04$ & 2.24E-06 & $1.80 \mathrm{E}-04$ & $3.60 \mathrm{E}-04$ & $1.32 \mathrm{E}-06$ & $2.72 \mathrm{E}-06$ \\
\hline
\end{tabular}

${ }^{\mathrm{a}} \mathrm{NOx}$ given as nitrogen dioxide $\left(\mathrm{NO}_{2}\right)$.

${ }^{\mathrm{b}} \mathrm{SOx}$ given as sulfur dioxide $\left(\mathrm{SO}_{2}\right)$

${ }^{c}$ Energy mix based on Energy Information Administration (EIA) International Energy Statistics for the year 2015.

${ }^{\mathrm{d}}$ Fossil energy mix based on EIA analysis, available at www.eia.gov/beta/international/analysis.php.

${ }^{\mathrm{e}}$ Emission factors based on relative fractions of each energy source for non-distributed power generation (coal, natural gas, oilfired, nuclear, biomass, hydro-eletric, geothermal, wind, and solar) obtained from The Greenhouse Gases, Regulated Emissions, and Energy Use in Transportation (GREET) Model, Argonne National Lab v.1.3.0.12842.

${ }^{\mathrm{f}}$ Distributed power generation, U.S. Mix, obtained from GREET. 
Table S26. Indirect emission factors of ingredient materials

\begin{tabular}{|c|c|c|c|c|c|c|c|}
\hline $\begin{array}{l}\text { Inventory Item } \\
(1 \mathrm{~kg})\end{array}$ & $\begin{array}{l}\mathrm{CO}_{2} \\
(\mathrm{~kg}) \\
\end{array}$ & $\begin{array}{l}\mathrm{CH}_{4} \\
(\mathrm{~kg}) \\
\end{array}$ & $\begin{array}{l}\mathrm{N}_{2} \mathrm{O} \\
(\mathrm{kg}) \\
\end{array}$ & $\begin{array}{l}\text { NOx } \\
(\mathrm{kg})\end{array}$ & $\begin{array}{l}\text { SOx } \\
(\mathrm{kg})\end{array}$ & $\begin{array}{l}\mathrm{BC} \\
(\mathrm{kg}) \\
\end{array}$ & $\begin{array}{l}\text { POC } \\
(\mathrm{kg})\end{array}$ \\
\hline Wheat-mix batter ${ }^{a}$ & $3.51 \mathrm{E}-01$ & $8.91 \mathrm{E}-04$ & $6.77 \mathrm{E}-05$ & $5.84 \mathrm{E}-04$ & $1.12 \mathrm{E}-03$ & $5.77 \mathrm{E}-06$ & $1.14 \mathrm{E}-05$ \\
\hline Tap water ${ }^{a}$ & $2.26 \mathrm{E}-04$ & $4.32 \mathrm{E}-07$ & 3.77E-09 & $1.62 \mathrm{E}-07$ & 4.14E-07 & $1.05 \mathrm{E}-09$ & $2.32 \mathrm{E}-09$ \\
\hline Breadcrumbs ${ }^{\text {a }}$ & $3.44 \mathrm{E}-01$ & $9.47 \mathrm{E}-04$ & $7.01 \mathrm{E}-05$ & $5.29 \mathrm{E}-04$ & 2.13E-02 & $3.66 \mathrm{E}-06$ & $8.61 \mathrm{E}-06$ \\
\hline Wheat starch ${ }^{\text {a }}$ & $9.93 \mathrm{E}-01$ & $3.45 \mathrm{E}-03$ & $9.61 \mathrm{E}-05$ & $1.56 \mathrm{E}-03$ & $1.77 \mathrm{E}-03$ & $1.29 \mathrm{E}-05$ & $2.90 \mathrm{E}-05$ \\
\hline Potato starch ${ }^{a}$ & $6.99 \mathrm{E}-01$ & $1.53 \mathrm{E}-03$ & $2.40 \mathrm{E}-05$ & $6.21 \mathrm{E}-04$ & $1.42 \mathrm{E}-03$ & $4.31 \mathrm{E}-06$ & $9.62 \mathrm{E}-06$ \\
\hline Sugar ${ }^{a}$ & $3.38 \mathrm{E}-01$ & $1.02 \mathrm{E}-03$ & 2.67E-04 & $1.09 \mathrm{E}-03$ & $3.47 \mathrm{E}-04$ & $5.50 \mathrm{E}-05$ & $1.26 \mathrm{E}-04$ \\
\hline Salt & $2.40 \mathrm{E}-01$ & $6.20 \mathrm{E}-04$ & $4.80 \mathrm{E}-06$ & $1.30 \mathrm{E}-03$ & $7.90 \mathrm{E}-04$ & $1.02 \mathrm{E}-05$ & $1.36 \mathrm{E}-05$ \\
\hline Crab extract ${ }^{a}$ & $2.35 \mathrm{E}+00$ & $5.90 \mathrm{E}-03$ & 4.10E-05 & $2.43 \mathrm{E}-03$ & $2.76 \mathrm{E}-03$ & $1.65 \mathrm{E}-05$ & $3.72 \mathrm{E}-05$ \\
\hline Crab flavoring $^{\mathrm{a}}$ & $1.17 \mathrm{E}+00$ & $2.94 \mathrm{E}-03$ & $2.04 \mathrm{E}-05$ & $1.21 \mathrm{E}-03$ & $1.38 \mathrm{E}-03$ & $8.21 \mathrm{E}-06$ & $1.85 \mathrm{E}-05$ \\
\hline Carrageenan $^{\mathrm{a}}$ & $1.46 \mathrm{E}+00$ & 3.67E-03 & $2.55 \mathrm{E}-05$ & $1.51 \mathrm{E}-03$ & $1.72 \mathrm{E}-03$ & $1.03 \mathrm{E}-05$ & $2.32 \mathrm{E}-05$ \\
\hline Kelp extract ${ }^{a}$ & $2.92 \mathrm{E}+00$ & 7.34E-03 & $5.10 \mathrm{E}-05$ & $3.02 \mathrm{E}-03$ & $3.44 \mathrm{E}-03$ & $2.05 \mathrm{E}-05$ & 4.64E-05 \\
\hline Albumen ${ }^{\text {a }}$ & $1.10 \mathrm{E}+00$ & $2.35 \mathrm{E}-03$ & $6.76 \mathrm{E}-04$ & $2.04 \mathrm{E}-03$ & $2.10 \mathrm{E}-03$ & $2.32 \mathrm{E}-05$ & $2.05 \mathrm{E}-05$ \\
\hline Calcium carbonate & $1.30 \mathrm{E}-02$ & $2.70 \mathrm{E}-05$ & $8.15 \mathrm{E}-08$ & $3.44 \mathrm{E}-05$ & $6.33 \mathrm{E}-06$ & $2.60 \mathrm{E}-07$ & $2.80 \mathrm{E}-07$ \\
\hline Soybean oil & $1.17 \mathrm{E}+00$ & $2.73 \mathrm{E}-03$ & $3.77 \mathrm{E}-03$ & $4.25 \mathrm{E}-03$ & 4.12E-03 & $1.10 \mathrm{E}-04$ & $4.98 \mathrm{E}-05$ \\
\hline Phosphate & $1.34 \mathrm{E}+00$ & $3.47 \mathrm{E}-03$ & $2.81 \mathrm{E}-05$ & $5.13 \mathrm{E}-03$ & $6.12 \mathrm{E}-02$ & $4.75 \mathrm{E}-05$ & $1.10 \mathrm{E}-04$ \\
\hline Seasoning mix ${ }^{a}$ & $1.17 \mathrm{E}+00$ & $2.94 \mathrm{E}-03$ & $2.04 \mathrm{E}-05$ & $1.21 \mathrm{E}-03$ & $1.38 \mathrm{E}-03$ & $8.21 \mathrm{E}-06$ & $1.85 \mathrm{E}-05$ \\
\hline Red colorant ${ }^{\mathrm{a}}$ & $1.46 \mathrm{E}+00$ & $3.67 \mathrm{E}-03$ & $2.55 \mathrm{E}-05$ & $1.51 \mathrm{E}-03$ & $1.72 \mathrm{E}-03$ & $1.03 \mathrm{E}-05$ & $2.32 \mathrm{E}-05$ \\
\hline Distilled water ${ }^{a}$ & $1.22 \mathrm{E}-03$ & $2.64 \mathrm{E}-06$ & $1.92 \mathrm{E}-08$ & $1.04 \mathrm{E}-06$ & $1.22 \mathrm{E}-05$ & $3.47 \mathrm{E}-09$ & $1.07 \mathrm{E}-08$ \\
\hline Sunflower oil ${ }^{\text {a }}$ & $9.87 \mathrm{E}-01$ & $2.09 \mathrm{E}-03$ & $1.02 \mathrm{E}-04$ & $1.05 \mathrm{E}-03$ & $1.66 \mathrm{E}-03$ & $6.50 \mathrm{E}-06$ & $1.42 \mathrm{E}-05$ \\
\hline
\end{tabular}

${ }^{\mathrm{a}}$ Datasets available at: https://doi.org/10.6071/M3HW93. 
Table S27: Mean global metric global warming potentials.

\begin{tabular}{lcc}
\hline $\mathrm{GWP}^{\mathrm{a}, \mathrm{b}}$ & $20-\mathrm{y}$ & $100-\mathrm{y}$ \\
\hline $\mathrm{CO}_{2}{ }^{\mathrm{c}, \mathrm{d}}$ & 1 & 1 \\
$\mathrm{CH}_{4}{ }^{\mathrm{c}, \mathrm{d}}$ & 86 & 34 \\
$\mathrm{~N}_{2} \mathrm{O}^{\mathrm{c}, \mathrm{d}}$ & 268 & 298 \\
$\mathrm{NOx}^{\mathrm{d}, \mathrm{e}, \mathrm{f},}$ & 16.7 & -11 \\
$\mathrm{SO}_{2}{ }^{\mathrm{d}, \mathrm{f}}$ & -141 & -38 \\
$\mathrm{BC}^{\mathrm{d}, \mathrm{f}}$ & 2421 & 659 \\
$\mathrm{OC}^{\mathrm{d}, \mathrm{f}}$ & -244 & -66 \\
$\mathrm{CF}_{4}{ }^{\mathrm{c}, \mathrm{g}, \mathrm{h}}$ & 4954 & 7349 \\
$\mathrm{C}_{2} \mathrm{~F}_{6}{ }^{\mathrm{c}, \mathrm{g}, \mathrm{i}}$ & 8344 & 12340 \\
$\mathrm{CFC}^{\mathrm{c}} 12^{\mathrm{c}, \mathrm{g}}$ & 10976 & 11547 \\
$\mathrm{CFC}^{\mathrm{c}}-113^{\mathrm{c}, \mathrm{g}}$ & 6600 & 6586 \\
$\mathrm{HCFC}^{\mathrm{C}}-124^{\mathrm{c}, \mathrm{g}}$ & 1920 & 635 \\
$\mathrm{R}-134 \mathrm{a}^{\mathrm{c}, \mathrm{g}}$ & 3789 & 1549 \\
$\mathrm{R}-404 \mathrm{a}^{\mathrm{c}, \mathrm{g}, \mathrm{j}}$ & 6556 & 4550 \\
\hline
\end{tabular}

${ }^{\mathrm{a}}$ Global warming potential (GWP)

${ }^{\mathrm{b}}$ Given in $\mathrm{kg}$ of carbon dioxide equivalents $\left(\mathrm{CO}_{2} \mathrm{e}\right)$ per kg pollutant.

${ }^{c}$ Values include carbon-climate feedback.

${ }^{\mathrm{d}}$ Data source (Myhre et al., 2013), conf. Table 8.SM.17.

${ }^{\mathrm{e}}$ Given as $\mathrm{NO}_{2}$.

${ }^{\mathrm{f}}$ Direct effects (aerosol-radiation interaction)

${ }^{\mathrm{g}}$ Data source (Myhre et al., 2013), conf. Table 8.SM.16.

${ }^{\mathrm{h}} \mathrm{PFC}-14$

${ }^{i} \mathrm{PFC}-116$

${ }^{\mathrm{j}} \mathrm{GWP}$ of R-404a data unavailable; according product information (www.daikin.com/chm/products/pdfDown.php?url=pdf/tds/tds_r404a_e.pdf), R-404a is blend refrigerant made of the following components: $44 \%$ HFC-125, 52\% HFC-143a, and 4\% HFC-134a; these components were used to estimate the GWP. 
Table S28. Shipping sector global warming potentials of short-lived pollutants

\begin{tabular}{lllll}
\hline $\mathrm{GWP}^{\mathrm{a}, \mathrm{b}}$ & $\mathrm{NOx}^{\mathrm{c}, \mathrm{d}}$ & $\mathrm{SO}_{2}^{\mathrm{cec}}$ & $\mathrm{BC}^{\mathrm{c}, \mathrm{f}}$ & $\mathrm{OC}^{\mathrm{c}, \mathrm{f}}$ \\
\hline $20-\mathrm{y}$ & $-69( \pm 12)$ & $-171( \pm 70)$ & $2317( \pm 647)$ & $-673( \pm 379)$ \\
$100-\mathrm{y}$ & $-43( \pm 8)$ & $-46( \pm 19)$ & $650( \pm 180)$ & $-185( \pm 102)$ \\
\hline
\end{tabular}

${ }^{\mathrm{a}}$ Global warming potential (GWP)

${ }^{\mathrm{b}}$ Given in $\mathrm{kg}$ of carbon dioxide equivalents $\left(\mathrm{CO}_{2} \mathrm{e}\right)$ per kg pollutant.

${ }^{\mathrm{c}}$ Direct effects (aerosol-radiation interaction).

${ }^{\mathrm{d}}$ Mean values and standard error (n=5); (Eyring et al., 2007), (Endresen et al., 2003), and (Fuglestvedt et al., 2008) as reported in (Fuglestvedt et al., 2010); (Collins et al., 2010) as reported in (Myhre et al., 2013) (conf. Table 8.SM.18); (Aamaas et al., 2015) (average of summer and winter values).

${ }^{\mathrm{e}}$ Mean values and standard error (n=5); (Eyring et al., 2007), (Endresen et al., 2003), (Lauer et al., 2007), and (Fuglestvedt et al., 2008) as reported in (Fuglestvedt et al., 2010); (Aamaas et al., 2015) (average of summer and winter values)..

${ }^{\mathrm{f}}$ Mean values and standard error (n=3); (Fuglestvedt et al., 2010); (Aamaas et al., 2015) (average of summer and winter values); (Myhre et al., 2013) transport value (conf. Table 8.SM.18). 
Table S29. Sensitivity analysis parameters of the seafood supply-chain: values included in the standard deviations.

\begin{tabular}{|c|c|c|c|}
\hline Sensitivity parameter & Min & Mean & Max \\
\hline $\mathrm{AFA}^{\mathrm{a}}$ total catch $(\mathrm{kg})$ & $4.66 \mathrm{E}+08$ & $4.83 \mathrm{E}+08$ & $5.00 \mathrm{E}+08$ \\
\hline At-sea pollock catch $(\mathrm{kg})$ & $5.75 \mathrm{E}+08$ & $6.09 \mathrm{E}+08$ & $6.43 \mathrm{E}+08$ \\
\hline At-sea pollock products $(\mathrm{kg})$ & $2.46 \mathrm{E}+08$ & $2.77 \mathrm{E}+08$ & $3.08 \mathrm{E}+08$ \\
\hline At-sea fillets (kg) & $7.46 \mathrm{E}+07$ & $9.23 \mathrm{E}+07$ & $1.10 \mathrm{E}+08$ \\
\hline At-sea surimi $(\mathrm{kg})$ & $6.96 \mathrm{E}+07$ & $8.56 \mathrm{E}+07$ & $1.02 \mathrm{E}+08$ \\
\hline f At-sea fillets (-) & 5.34E-01 & $5.59 \mathrm{E}-01$ & $5.85 \mathrm{E}-01$ \\
\hline Mass of fillets to Germany $(\mathrm{kg})$ & $2.62 \mathrm{E}+07$ & $6.50 \mathrm{E}+07$ & $1.04 \mathrm{E}+08$ \\
\hline Mass of fillets to Netherlands (kg) & $2.06 \mathrm{E}+07$ & $2.43 \mathrm{E}+07$ & $2.80 \mathrm{E}+07$ \\
\hline Mass of fillets to domestic market $(\mathrm{kg})$ & $2.95 \mathrm{E}+07$ & $5.26 \mathrm{E}+07$ & $7.58 \mathrm{E}+07$ \\
\hline f At-sea surimi (-) & 4.80E-01 & $5.05 \mathrm{E}-01$ & $5.31 \mathrm{E}-01$ \\
\hline Mass of surimi to Japan (kg) & $4.82 \mathrm{E}+07$ & $6.94 \mathrm{E}+07$ & $9.06 \mathrm{E}+07$ \\
\hline Mass of surimi to South Korea (kg) & $4.08 \mathrm{E}+07$ & $5.59 \mathrm{E}+07$ & $7.11 \mathrm{E}+07$ \\
\hline Mass of surimi to domestic market $(\mathrm{kg})$ & $5.48 \mathrm{E}+06$ & $1.60 \mathrm{E}+07$ & $2.66 \mathrm{E}+07$ \\
\hline $\mathrm{BC}$ emission factor $\left(\mathrm{g} \mathrm{kg}\right.$ fuel $\left.^{-1}\right)$ & 0.57 & 0.85 & 1.13 \\
\hline f fuel primary processing (-) & 0.04 & 0.06 & 0.08 \\
\hline Light ship weight (metric tons) & 2,718 & 8,372 & 14,027 \\
\hline Main engine fuel consumption (liters) & $5.12 \mathrm{E}+07$ & $6.88 \mathrm{E}+07$ & $8.64 \mathrm{E}+07$ \\
\hline Mass of main engine (metric tons) & 25.5 & 40.3 & 55.1 \\
\hline Number of vessels (-) & 13.1 & 14.8 & 16.5 \\
\hline OC emission factor $\left(\mathrm{g} \mathrm{kg}\right.$ fuel $\left.^{-1}\right)$ & 0.67 & 0.99 & 0.67 \\
\hline Shipping BC GWP, 20-y time horizon $\left(\mathrm{kg} \mathrm{CO}_{2} \mathrm{e} \mathrm{kg}\right.$ pollutant $\left.{ }^{-1}\right)$ & 1,023 & 2,317 & 3,611 \\
\hline Shipping BC GWP, 100-y time horizon $\left(\mathrm{kg} \mathrm{CO}_{2} \mathrm{e} \mathrm{kg} \mathrm{pollutant}{ }^{-1}\right)$ & 290 & 650 & 1,010 \\
\hline Shipping NOx GWP, 20 -y time horizon $\left(\mathrm{kg} \mathrm{CO}_{2} \mathrm{e} \mathrm{kg} \mathrm{pollutant}{ }^{-1}\right)$ & -93 & -69 & -45 \\
\hline Shipping NOx GWP, 100-y time horizon $\left(\mathrm{kg} \mathrm{CO}_{2} \mathrm{e} \mathrm{kg} \mathrm{pollutant}{ }^{-1}\right)$ & -59 & -43 & -27 \\
\hline Shipping OC GWP, 20-y time horizon $\left(\mathrm{kg} \mathrm{CO}_{2} \mathrm{e} \mathrm{kg}\right.$ pollutant $\left.{ }^{-1}\right)$ & $-1,431$ & -673 & 85 \\
\hline Shipping OC GWP, 100 -y time horizon $\left(\mathrm{kg} \mathrm{CO}_{2} \mathrm{e} \mathrm{kg} \mathrm{pollutant}{ }^{-1}\right)$ & -389 & -185 & 19 \\
\hline Shipping SOx GWP, 20-y time horizon $\left(\mathrm{kg} \mathrm{CO}_{2} \mathrm{e} \mathrm{kg} \mathrm{pollutant}{ }^{-1}\right)$ & -311 & -171 & -31 \\
\hline Shipping SOx GWP, 100 -y time horizon $\left(\mathrm{kg} \mathrm{CO}_{2} \mathrm{e} \mathrm{kg} \mathrm{pollutant}{ }^{-1}\right)$ & -86 & -46 & -6 \\
\hline
\end{tabular}


Table S30. Sensitivity analysis of highly uncertain parameters of the fishing phase of the seafood supply-chain

\begin{tabular}{|c|c|c|c|}
\hline Sensitivity parameter & Min & $\begin{array}{l}\text { Best } \\
\text { Estimate }\end{array}$ & $\operatorname{Max}$ \\
\hline Pelagic trawl gear lifetime $(y)^{a}$ & 2.5 & 5 & 7.5 \\
\hline Ship paint lifetime (y) ${ }^{\mathrm{b}}$ & 1 & 2 & 3 \\
\hline Ship main engine lifetime $(y)^{c}$ & 7.5 & 15 & 22.5 \\
\hline Ship lifetime $(y)^{d}$ & 15 & 30 & 45 \\
\hline Ship air conditioning refrigerant ${ }^{e}$ leakage rate $\left(y^{-1}\right)^{f}$ & 0.15 & 0.3 & 0.45 \\
\hline $\begin{array}{l}{ }^{a} \text { Min and max represent arbitrary values set as half the lifetime } \\
{ }^{b} \text { Range of values reported in (Ziegler et al., 2015). } \\
{ }^{\mathrm{c}} \text { Range of values reported in (Fréon et al., 2014). } \\
{ }^{d} \text { Range of values reported in (Ziegler et al., 2015). } \\
{ }^{e} \text { R-404a. } \\
{ }^{2} \text { Range of values reported in (Smith et al., 2014). }\end{array}$ & orted in & ton, 2010). & \\
\hline
\end{tabular}


Table S31. Sensitivity analysis of highly uncertain parameters of the primary processing phase of the seafood supply-chain

\begin{tabular}{|c|c|c|c|}
\hline Sensitivity parameter & Min & $\begin{array}{l}\text { Best } \\
\text { Estimate }\end{array}$ & Max \\
\hline Storage freezer refrigerant ${ }^{a}$ lifetime $(y)^{b}$ & 8.4 & 11.7 & 15 \\
\hline Initial charge for storage freezer $\left(\mathrm{kg} \mathrm{NH}_{3} \mathrm{~m}^{-3}\right)^{\mathrm{b}}$ & 0.048 & 0.144 & 0.24 \\
\hline Storage refrigerant ${ }^{a}$ leak rate $\left(\mathrm{y}^{-1}\right)^{\mathrm{b}}$ & 0.03 & 0.09 & 0.15 \\
\hline Primary processing storage time $(d)^{c}$ & 30 & 60 & 90 \\
\hline Ship freezer refrigerant ${ }^{\mathrm{d}}$ leak rate $\left(\mathrm{y}^{-1}\right)^{\mathrm{e}}$ & 0.15 & 0.3 & 0.45 \\
\hline
\end{tabular}

${ }^{\mathrm{a}}$ Ammonia $\left(\mathrm{NH}_{3}\right)$ refrigerant.

${ }^{\mathrm{b}}$ Range of values reported in (Bovea et al., 2007; Blowers and Lownsbury, 2010; Cascini et al., 2016).

${ }^{\mathrm{c}}$ Range of values reported in (Winther et al., 2009).

${ }^{\mathrm{d}} \mathrm{R}-134$ a refrigerant.

${ }^{\mathrm{e}}$ Range of values reported in (Smith et al., 2014). 
Table S32. Sensitivity analysis parameters of the transportation to secondary processor phase of the seafood supply-chain: highly uncertain values not included in the standard deviations

\begin{tabular}{|c|c|c|c|}
\hline Sensitivity Parameter & Min & $\begin{array}{l}\text { Best } \\
\text { Estimate }\end{array}$ & $\operatorname{Max}$ \\
\hline Ship distance, Germany $(\mathrm{km})^{\mathrm{a}}$ & $1.20 \mathrm{E}+04$ & $1.94 \mathrm{E}+04$ & \\
\hline Ship distance, Netherlands $(\mathrm{km})^{\mathrm{a}}$ & $1.19 \mathrm{E}+04$ & $1.89 \mathrm{E}+04$ & \\
\hline Ship distance, Japan $(\mathrm{km})^{\mathrm{b}}$ & & $5.00 \mathrm{E}+03$ & $5.71 \mathrm{E}+03$ \\
\hline Ship distance, South Korea $(\mathrm{km})^{\mathrm{b}}$ & & $5.50 \mathrm{E}+03$ & $5.91 \mathrm{E}+03$ \\
\hline Ship cruising speed $\left(\mathrm{km} \mathrm{h}^{-1}\right)^{\mathrm{c}}$ & $3.33 \mathrm{E}+01$ & $3.61 \mathrm{E}+01$ & $3.89 \mathrm{E}+01$ \\
\hline Ship reduced-speed-zone speed $\left(\mathrm{km} \mathrm{h}^{-1}\right)^{\mathrm{d}}$ & $1.67 \mathrm{E}+01$ & $1.94 \mathrm{E}+01$ & $2.22 \mathrm{E}+01$ \\
\hline Ship hotel load factor $(-)^{\mathrm{e}}$ & $1.70 \mathrm{E}-01$ & $2.00 \mathrm{E}-01$ & $2.30 \mathrm{E}-01$ \\
\hline Ship hotel time (hours) ${ }^{\mathrm{f}}$ & $1.40 \mathrm{E}+01$ & $4.10 \mathrm{E}+01$ & $5.40 \mathrm{E}+01$ \\
\hline Ship HFO sulfur level (\% wt.) ${ }^{\mathrm{g}}$ & $1.30 \mathrm{E}+00$ & $2.40 \mathrm{E}+00$ & $3.50 \mathrm{E}+00$ \\
\hline Ship HFO sulfur level in 2020 (\% wt. $)^{\mathrm{h}}$ & $5.00 \mathrm{E}-01$ & $2.40 \mathrm{E}+00$ & \\
\hline f Ship fuel for temperature-controlled containers ${ }^{i}$ & $8.00 \mathrm{E}-02$ & $1.90 \mathrm{E}-01$ & $3.00 \mathrm{E}-01$ \\
\hline Heavy-duty truck distance, Germany $(\mathrm{km})^{\mathrm{j}}$ & $2.50 \mathrm{E}+00$ & $1.67 \mathrm{E}+02$ & $2.54 \mathrm{E}+02$ \\
\hline Heavy-duty truck distance, Netherlands $(\mathrm{km})^{\mathrm{j}}$ & $2.50 \mathrm{E}+00$ & $1.79 \mathrm{E}+02$ & $2.54 \mathrm{E}+02$ \\
\hline Heavy-duty truck distance, Japan $(\mathrm{km})^{\mathrm{j}}$ & $2.50 \mathrm{E}+00$ & $1.25 \mathrm{E}+01$ & $2.54 \mathrm{E}+02$ \\
\hline Heavy-duty truck distance, South Korea $(\mathrm{km})^{\mathrm{j}}$ & & $2.50 \mathrm{E}+00$ & $2.54 \mathrm{E}+02$ \\
\hline Heavy-duty truck distance, domestic market $(\mathrm{km})^{\mathrm{j}}$ & $2.50 \mathrm{E}+00$ & $1.69 \mathrm{E}+01$ & $2.54 \mathrm{E}+02$ \\
\hline Heavy-duty truck fuel for temperature-controlled containers $\left(1 \mathrm{TEU}-\mathrm{h}^{-1}\right)^{\mathrm{k}}$ & $1.50 \mathrm{E}+00$ & $3.00 \mathrm{E}+00$ & $4.00 \mathrm{E}+00$ \\
\hline f refrigerant leak for temperature-controlled containers ${ }^{\mathrm{k}}$ & $5.00 \mathrm{E}-02$ & $1.50 \mathrm{E}-01$ & $2.50 \mathrm{E}-01$ \\
\hline $\begin{array}{l}\text { a Assuming the Northwest Passage becomes a viable (ice-free) route (conf. route } 1 \\
\text { b Alternate route estimated by the Marine Traffic Voyage Planner (conf. route } 2 \text { in } \\
\text { b } \\
\text { c Range of values reported by (Rodrigue et al., 2013). } \\
\text { d Range of values reported by (Yau et al., 2012). } \\
{ }^{\text {e }} \text { Range of values reported by (Moreno-Gutiérrez et al., 2015) } \\
{ }^{\mathrm{f}} \text { Range of values reported by (United Nations Conference on Trade and Developm } \\
{ }^{\mathrm{g}} \text { Mean sulfur level of heavy fuel oil (HFO) of } 2.4 \text { (\% wt.) is the GREET Marine pl } \\
\text { of } 3.5 \text { (\% wt) is the global maximum; the minimum (min) HFO sulfur level of } 1.3 \\
\text { was the maximum and } 2.4 \text { (\% wt) is the mean value (Smith et al., 2014). } \\
{ }^{h} \text { Proposed maximum HFO sulfur level in } 2020 \text { (Smith et al., 2014). } \\
{ }^{\mathrm{i}} \text { Range of values reported in (Fitzgerald et al., 2011) } \\
{ }^{\mathrm{j}} \text { Range of distances we assumed (conf. Table S6). } \\
{ }^{k} \text { Range of values reported in (Tassou et al., 2009). }\end{array}$ & $\begin{array}{l}\mathrm{nt}, 2018)(\mathrm{co} \\
\mathrm{g} \text {-in value; } \mathrm{m} \\
\% \text { wt.) was ca }\end{array}$ & $\begin{array}{l}\text { f. Chapter 4). } \\
\text { aximum (max } \\
\text { culated assum }\end{array}$ & $\begin{array}{l}\text { IFO sulfur level } \\
\text { g } 3.5 \text { (\% wt.) }\end{array}$ \\
\hline
\end{tabular}


Table S33. Sensitivity analysis of highly uncertain parameters of transportation to retailer

\begin{tabular}{|c|c|c|c|}
\hline Sensitivity Parameter & Min & $\begin{array}{l}\text { Best } \\
\text { Estimate }\end{array}$ & Max \\
\hline Ship cruising speed $\left(\mathrm{km} \mathrm{h}^{-1}\right)^{\mathrm{a}}$ & $3.33 \mathrm{E}+01$ & $3.61 \mathrm{E}+01$ & $3.89 \mathrm{E}+01$ \\
\hline Ship reduced-speed-zone speed $\left(\mathrm{km} \mathrm{h}^{-1}\right)^{\mathrm{b}}$ & $1.67 \mathrm{E}+01$ & $1.94 \mathrm{E}+01$ & $2.22 \mathrm{E}+01$ \\
\hline Ship hotel load factor $(-)^{\mathrm{c}}$ & $1.70 \mathrm{E}-01$ & $2.00 \mathrm{E}-01$ & $2.30 \mathrm{E}-01$ \\
\hline Ship hotel time (hours) ${ }^{d}$ & $1.40 \mathrm{E}+01$ & $4.10 \mathrm{E}+01$ & $5.40 \mathrm{E}+01$ \\
\hline Ship HFO sulfur level (\% wt.) ${ }^{e}$ & $1.30 \mathrm{E}+00$ & $2.40 \mathrm{E}+00$ & $3.50 \mathrm{E}+00$ \\
\hline Ship HFO sulfur level in 2020 (\% wt.) ${ }^{\mathrm{f}}$ & $5.00 \mathrm{E}-01$ & $2.40 \mathrm{E}+00$ & \\
\hline f Ship fuel for temperature-controlled container ${ }^{g}$ & $8.00 \mathrm{E}-02$ & $1.90 \mathrm{E}-01$ & $3.00 \mathrm{E}-01$ \\
\hline Heavy-duty truck distance, Germany $(\mathrm{km})^{\mathrm{h}}$ & $3.91 \mathrm{E}+02$ & $1.50 \mathrm{E}+03$ & $2.34 \mathrm{E}+03$ \\
\hline Heavy-duty truck distance, Netherlands $(\mathrm{km})^{\mathrm{h}}$ & $3.91 \mathrm{E}+02$ & $1.50 \mathrm{E}+03$ & $2.34 \mathrm{E}+03$ \\
\hline Heavy-duty truck distance, Japan $(\mathrm{km})^{\mathrm{h}}$ & $3.91 \mathrm{E}+02$ & $1.02 \mathrm{E}+03$ & $2.34 \mathrm{E}+03$ \\
\hline Heavy-duty truck distance, South Korea $(\mathrm{km})^{\mathrm{h}}$ & & $3.91 \mathrm{E}+02$ & $2.34 \mathrm{E}+03$ \\
\hline Heavy-duty truck distance, domestic market $(\mathrm{km})^{\mathrm{h}}$ & $3.91 \mathrm{E}+02$ & $2.34 \mathrm{E}+03$ & \\
\hline Heavy-duty truck fuel for temperature-controlled container $\left(1 \mathrm{TEU}-\mathrm{h}^{-1}\right)^{\mathrm{i}}$ & $1.50 \mathrm{E}+00$ & $3.00 \mathrm{E}+00$ & $4.00 \mathrm{E}+00$ \\
\hline f refrigerant leak for temperature-controlled container ${ }^{i}$ & $5.00 \mathrm{E}-02$ & $1.50 \mathrm{E}-01$ & $2.50 \mathrm{E}-01$ \\
\hline
\end{tabular}

\footnotetext{
${ }^{a}$ Range of values reported by (Rodrigue et al., 2013).

${ }^{\mathrm{b}}$ Range of values reported by (Yau et al., 2012).

${ }^{\mathrm{c}}$ Range of values reported by (Moreno-Gutiérrez et al., 2015).

${ }^{\mathrm{d}}$ Range of values reported by (United Nations Conference on Trade and Development, 2018) (conf. Chapter 4).

${ }^{\mathrm{e}}$ Mean sulfur level of heavy fuel oil (HFO) of 2.4 (\% wt.) is the GREET Marine plug-in value; maximum (max) HFO sulfur level of $3.5(\% \mathrm{wt})$ is the global maximum; the minimum ( $\mathrm{min}) \mathrm{HFO}$ sulfur level of 1.3 (\% wt.) was calculated assuming 3.5 (\% wt.) was the maximum and 2.4 (\% wt) is the mean value (Smith et al., 2014).

${ }^{\mathrm{f}}$ Proposed maximum HFO sulfur level in 2020 (Smith et al., 2014).

${ }^{\mathrm{g}}$ Range of values reported in (Fitzgerald et al., 2011)

${ }^{\mathrm{h}}$ Range of distances we assumed (conf. Table S7).

${ }^{\mathrm{i}}$ Range of values reported in (Tassou et al., 2009).
} 
Table S34. Sensitivity analysis of highly uncertain parameters of the retail phase of the seafood supply-chain

\begin{tabular}{|c|c|c|c|}
\hline Sensitivity parameter & Min & $\begin{array}{l}\text { Best } \\
\text { Estimate }\end{array}$ & Max \\
\hline Storage refrigerant ${ }^{a}$ leak rate $\left(\mathrm{y}^{-1}\right)^{\mathrm{b}}$ & 0.03 & 0.09 & 0.15 \\
\hline Retail distribution storage time $(\mathrm{d})^{\mathrm{c}}$ & 5 & 10 & 15 \\
\hline Retail storage time $(\mathrm{d}){ }^{\mathrm{c}}$ & 4 & 7 & 10 \\
\hline Retail display time $(\mathrm{d})^{\mathrm{c}}$ & 4 & 7 & 10 \\
\hline Ancillary electricity consumption $\left(\mathrm{kWh} \mathrm{m}^{-2} \mathrm{y}^{-1}\right)^{\mathrm{d}}$ & 850 & 1,175 & 1,500 \\
\hline f Ancillary electricity not allocated to refrigeration ${ }^{d}$ & 0.40 & 0.55 & 0.70 \\
\hline
\end{tabular}


Table S35. Alternate emission factors for the non-ingredient materials used in the sensitivity analysis $^{\text {a }}$

\begin{tabular}{|c|c|c|c|c|c|c|c|c|}
\hline $\begin{array}{l}\text { Inventory Item } \\
(1 \mathrm{~kg})\end{array}$ & $\begin{array}{l}\mathrm{CO}_{2} \\
(\mathrm{~kg})\end{array}$ & $\begin{array}{l}\mathrm{CH}_{4} \\
(\mathrm{~kg})\end{array}$ & $\begin{array}{l}\mathrm{N}_{2} \mathrm{O} \\
(\mathrm{kg})\end{array}$ & $\begin{array}{l}\text { NOx } \\
(\mathrm{kg})\end{array}$ & $\begin{array}{l}\text { SOx } \\
(\mathrm{kg})\end{array}$ & $\begin{array}{c}\text { PM2.5 } \\
(\mathrm{kg})\end{array}$ & $\begin{array}{l}\mathrm{BC} \\
(\mathrm{kg})\end{array}$ & $\begin{array}{l}\text { POC } \\
(\mathrm{kg})\end{array}$ \\
\hline Lubricant oil & $9.60 \mathrm{E}-01$ & $3.21 \mathrm{E}-03$ & $1.91 \mathrm{E}-05$ & $2.87 \mathrm{E}-03$ & $6.59 \mathrm{E}-03$ & $3.08 \mathrm{E}-04$ & $4.62 \mathrm{E}-05$ & $1.20 \mathrm{E}-04$ \\
\hline Steel & $1.70 \mathrm{E}+00$ & $3.13 \mathrm{E}-03$ & $3.66 \mathrm{E}-05$ & $2.82 \mathrm{E}-03$ & $4.08 \mathrm{E}-03$ & 6.07E-04 & $4.42 \mathrm{E}-05$ & $1.01 \mathrm{E}-04$ \\
\hline Copper wire & $1.73 \mathrm{E}+00$ & $2.67 \mathrm{E}-03$ & $8.40 \mathrm{E}-05$ & $6.82 \mathrm{E}-03$ & $2.66 \mathrm{E}-02$ & $2.65 \mathrm{E}-03$ & $1.93 \mathrm{E}-04$ & 4.39E-04 \\
\hline Aluminum & $2.45 \mathrm{E}+00$ & $1.28 \mathrm{E}-03$ & $3.80 \mathrm{E}-06$ & $3.82 \mathrm{E}-03$ & $2.00 \mathrm{E}-02$ & $3.04 \mathrm{E}-10$ & $3.19 \mathrm{E}-11$ & $9.60 \mathrm{E}-11$ \\
\hline Cast iron & $1.35 \mathrm{E}+00$ & 4.80E-03 & $1.63 \mathrm{E}-05$ & $3.31 \mathrm{E}-03$ & $3.32 \mathrm{E}-03$ & $9.53 \mathrm{E}-04$ & $1.00 \mathrm{E}-04$ & $3.01 \mathrm{E}-04$ \\
\hline Chrome & $2.29 \mathrm{E}+00$ & $4.40 \mathrm{E}-03$ & $4.78 \mathrm{E}-05$ & 4.50E-03 & $6.54 \mathrm{E}-03$ & $2.41 \mathrm{E}-03$ & $2.53 \mathrm{E}-04$ & 7.61E-04 \\
\hline Anti-fouling paint & $2.27 \mathrm{E}+00$ & $6.71 \mathrm{E}-03$ & $1.31 \mathrm{E}-03$ & $1.30 \mathrm{E}-02$ & 4.35E-02 & $4.31 \mathrm{E}-03$ & 4.53E-04 & $1.34 \mathrm{E}-03$ \\
\hline Primer paint & $5.93 \mathrm{E}+00$ & $3.11 \mathrm{E}-02$ & $8.81 \mathrm{E}-07$ & $3.51 \mathrm{E}-02$ & $1.90 \mathrm{E}-02$ & $3.75 \mathrm{E}-03$ & $4.00 \mathrm{E}-04$ & $9.70 \mathrm{E}-04$ \\
\hline Polyurethane paint & $4.02 \mathrm{E}+00$ & $3.17 \mathrm{E}-02$ & $3.60 \mathrm{E}-05$ & $9.49 \mathrm{E}-03$ & $1.26 \mathrm{E}-02$ & $1.66 \mathrm{E}-03$ & $1.77 \mathrm{E}-04$ & $4.29 \mathrm{E}-04$ \\
\hline Enamel paint & $2.44 \mathrm{E}+00$ & 8.03E-03 & $7.14 \mathrm{E}-04$ & $7.60 \mathrm{E}-03$ & $1.26 \mathrm{E}-02$ & $5.40 \mathrm{E}-04$ & $5.76 \mathrm{E}-05$ & $1.40 \mathrm{E}-04$ \\
\hline Nylon & $5.53 \mathrm{E}+00$ & 4.68E-02 & 8.61E-03 & $1.87 \mathrm{E}-02$ & $1.66 \mathrm{E}-02$ & 7.33E-04 & $7.89 \mathrm{E}-05$ & $1.89 \mathrm{E}-04$ \\
\hline Lead & 3.92E-01 & 7.14E-04 & $1.18 \mathrm{E}-04$ & $1.17 \mathrm{E}-02$ & $1.31 \mathrm{E}-03$ & $5.18 \mathrm{E}-04$ & $3.40 \mathrm{E}-05$ & $7.15 \mathrm{E}-05$ \\
\hline Polyethylene & $1.91 \mathrm{E}+00$ & $1.12 \mathrm{E}-03$ & $1.98 \mathrm{E}-05$ & 5.92E-03 & $1.72 \mathrm{E}-02$ & $2.00 \mathrm{E}-07$ & $1.72 \mathrm{E}-08$ & $3.86 \mathrm{E}-08$ \\
\hline Poly-steel & $1.96 \mathrm{E}+00$ & 2.01E-03 & $6.06 \mathrm{E}-06$ & $5.68 \mathrm{E}-03$ & $2.67 \mathrm{E}-02$ & $7.63 \mathrm{E}-06$ & $8.05 \mathrm{E}-07$ & $1.91 \mathrm{E}-06$ \\
\hline Polypropylene & 7.91E-01 & $1.93 \mathrm{E}-03$ & 7.59E-06 & $2.37 \mathrm{E}-03$ & $2.58 \mathrm{E}-02$ & $1.10 \mathrm{E}-07$ & $1.39 \mathrm{E}-08$ & $3.43 \mathrm{E}-08$ \\
\hline Ammonia & $1.99 \mathrm{E}+00$ & $3.91 \mathrm{E}-03$ & $3.04 \mathrm{E}-05$ & $2.43 \mathrm{E}-03$ & 4.37E-03 & $5.54 \mathrm{E}-04$ & $6.13 \mathrm{E}-05$ & $1.47 \mathrm{E}-04$ \\
\hline Cardboard & 8.70E-01 & $1.77 \mathrm{E}-03$ & $6.25 \mathrm{E}-05$ & $2.47 \mathrm{E}-03$ & $1.29 \mathrm{E}-03$ & $2.69 \mathrm{E}-04$ & $3.16 \mathrm{E}-05$ & 7.75E-05 \\
\hline Plastic bag & $2.25 \mathrm{E}+00$ & $1.74 \mathrm{E}-02$ & $1.43 \mathrm{E}-05$ & 4.84E-03 & $6.57 \mathrm{E}-03$ & 3.04E-04 & 2.63E-05 & $5.90 \mathrm{E}-05$ \\
\hline Liner & 7.77E-01 & $1.46 \mathrm{E}-02$ & 7.92E-05 & $3.73 \mathrm{E}-03$ & $3.15 \mathrm{E}-03$ & $5.78 \mathrm{E}-04$ & $3.86 \mathrm{E}-05$ & $8.04 \mathrm{E}-05$ \\
\hline $\begin{array}{l}\text { Retractable } \\
\text { polyolefin }\end{array}$ & $2.25 \mathrm{E}+00$ & $1.74 \mathrm{E}-02$ & $1.43 \mathrm{E}-05$ & $4.84 \mathrm{E}-03$ & $6.57 \mathrm{E}-03$ & $3.04 \mathrm{E}-04$ & $2.63 \mathrm{E}-05$ & $5.89 \mathrm{E}-05$ \\
\hline Detergents & $8.21 \mathrm{E}-01$ & $3.30 \mathrm{E}-03$ & $6.12 \mathrm{E}-04$ & $3.57 \mathrm{E}-03$ & $2.20 \mathrm{E}-03$ & $2.69 \mathrm{E}-03$ & $2.49 \mathrm{E}-04$ & $5.78 \mathrm{E}-04$ \\
\hline Bleach & $8.38 \mathrm{E}-01$ & $1.47 \mathrm{E}-03$ & $2.30 \mathrm{E}-05$ & $1.84 \mathrm{E}-03$ & $2.59 \mathrm{E}-03$ & $2.34 \mathrm{E}-04$ & $1.89 \mathrm{E}-05$ & $4.31 \mathrm{E}-05$ \\
\hline Caustic soda & $1.04 \mathrm{E}+00$ & $1.78 \mathrm{E}-03$ & $3.22 \mathrm{E}-05$ & $1.94 \mathrm{E}-03$ & $3.52 \mathrm{E}-03$ & 2.93E-04 & $2.20 \mathrm{E}-05$ & $4.96 \mathrm{E}-05$ \\
\hline
\end{tabular}

${ }^{\mathrm{a}}$ Datasets available at: https://doi.org/10.6071/M3HW93. 
Table S36. Alternate emission factors of the ingredient materials used in the sensitivity analysis ${ }^{\text {a }}$

\begin{tabular}{lcccccccc}
\hline $\begin{array}{l}\text { Inventory Item } \\
(1 \mathrm{~kg})\end{array}$ & $\begin{array}{c}\mathrm{CO}_{2} \\
(\mathrm{~kg})\end{array}$ & $\begin{array}{c}\mathrm{CH}_{4} \\
(\mathrm{~kg})\end{array}$ & $\begin{array}{c}\mathrm{N}_{2} \mathrm{O} \\
(\mathrm{kg})\end{array}$ & $\begin{array}{c}\mathrm{NOx} \\
(\mathrm{kg})\end{array}$ & $\begin{array}{c}\mathrm{SOx} \\
(\mathrm{kg})\end{array}$ & $\begin{array}{c}\mathrm{PM} 2.5 \\
(\mathrm{~kg})\end{array}$ & $\begin{array}{c}\mathrm{BC} \\
(\mathrm{kg})\end{array}$ & $\begin{array}{c}\text { POC } \\
(\mathrm{kg})\end{array}$ \\
\hline $\begin{array}{l}\text { Wheat-mix } \\
\text { batter }\end{array}$ & $3.33 \mathrm{E}-01$ & $8.14 \mathrm{E}-04$ & $1.58 \mathrm{E}-04$ & $1.61 \mathrm{E}-03$ & $5.24 \mathrm{E}-04$ & & $7.00 \mathrm{E}-05$ & $5.73 \mathrm{E}-05$ \\
Tap water & $2.98 \mathrm{E}-04$ & $5.01 \mathrm{E}-07$ & $7.80 \mathrm{E}-09$ & $6.19 \mathrm{E}-07$ & $8.91 \mathrm{E}-07$ & $9.02 \mathrm{E}-08$ & $1.04 \mathrm{E}-08$ & $2.44 \mathrm{E}-08$ \\
Breadcrumbs & $3.26 \mathrm{E}-01$ & $8.31 \mathrm{E}-04$ & $1.87 \mathrm{E}-04$ & $1.56 \mathrm{E}-03$ & $1.13 \mathrm{E}-02$ & & $7.30 \mathrm{E}-04$ & $1.56 \mathrm{E}-03$ \\
Wheat starch & $9.76 \mathrm{E}-01$ & $3.44 \mathrm{E}-03$ & $3.17 \mathrm{E}-06$ & $2.95 \mathrm{E}-03$ & $9.92 \mathrm{E}-04$ & & $7.70 \mathrm{E}-05$ & $9.93 \mathrm{E}-05$ \\
Potato starch & $4.43 \mathrm{E}-01$ & $8.87 \mathrm{E}-04$ & $8.31 \mathrm{E}-04$ & $1.77 \mathrm{E}-03$ & $7.67 \mathrm{E}-04$ & & $5.06 \mathrm{E}-05$ & $5.90 \mathrm{E}-05$ \\
Sugar & $2.84 \mathrm{E}-01$ & $5.77 \mathrm{E}-04$ & $6.92 \mathrm{E}-04$ & $1.33 \mathrm{E}-03$ & $4.19 \mathrm{E}-04$ & $1.38 \mathrm{E}-04$ & $1.51 \mathrm{E}-05$ & $3.64 \mathrm{E}-05$ \\
Crab extract & $9.46 \mathrm{E}-01$ & $3.58 \mathrm{E}-03$ & $9.24 \mathrm{E}-04$ & $3.60 \mathrm{E}-03$ & $2.44 \mathrm{E}-03$ & $1.38 \mathrm{E}-03$ & $1.18 \mathrm{E}-04$ & $2.65 \mathrm{E}-04$ \\
Crab flavoring & $4.71 \mathrm{E}-01$ & $1.78 \mathrm{E}-03$ & $4.60 \mathrm{E}-04$ & $1.79 \mathrm{E}-03$ & $1.22 \mathrm{E}-03$ & $6.88 \mathrm{E}-04$ & $5.87 \mathrm{E}-05$ & $1.32 \mathrm{E}-04$ \\
Carrageenan & $5.89 \mathrm{E}-01$ & $2.23 \mathrm{E}-03$ & $5.75 \mathrm{E}-04$ & $2.24 \mathrm{E}-03$ & $1.52 \mathrm{E}-03$ & $8.60 \mathrm{E}-04$ & $7.33 \mathrm{E}-05$ & $1.65 \mathrm{E}-04$ \\
Kelp extract & $6.18 \mathrm{E}-01$ & $2.34 \mathrm{E}-03$ & $6.04 \mathrm{E}-04$ & $2.35 \mathrm{E}-03$ & $1.60 \mathrm{E}-03$ & $9.03 \mathrm{E}-04$ & $7.70 \mathrm{E}-05$ & $1.73 \mathrm{E}-04$ \\
Soybean oil & $7.66 \mathrm{E}-01$ & $1.05 \mathrm{E}-03$ & $3.47 \mathrm{E}-03$ & $6.80 \mathrm{E}-03$ & $3.02 \mathrm{E}-03$ & $3.77 \mathrm{E}-04$ & $2.64 \mathrm{E}-05$ & $3.49 \mathrm{E}-05$ \\
Phosphate & $1.35 \mathrm{E}+00$ & $2.05 \mathrm{E}-03$ & $2.33 \mathrm{E}-05$ & $3.76 \mathrm{E}-03$ & $3.09 \mathrm{E}-02$ & $7.53 \mathrm{E}-04$ & $5.77 \mathrm{E}-05$ & $1.04 \mathrm{E}-04$ \\
Seasoning mix & $4.71 \mathrm{E}-01$ & $1.78 \mathrm{E}-03$ & $4.60 \mathrm{E}-04$ & $1.79 \mathrm{E}-03$ & $1.22 \mathrm{E}-03$ & $6.88 \mathrm{E}-04$ & $5.87 \mathrm{E}-05$ & $1.32 \mathrm{E}-04$ \\
Red colorant & $5.89 \mathrm{E}-01$ & $2.23 \mathrm{E}-03$ & $5.75 \mathrm{E}-04$ & $2.24 \mathrm{E}-03$ & $1.52 \mathrm{E}-03$ & $8.60 \mathrm{E}-04$ & $7.33 \mathrm{E}-05$ & $1.65 \mathrm{E}-04$ \\
Sunflower oil & $9.40 \mathrm{E}-01$ & $1.38 \mathrm{E}-03$ & $5.22 \mathrm{E}-03$ & $6.31 \mathrm{E}-03$ & $2.10 \mathrm{E}-03$ & & $5.56 \mathrm{E}-04$ & $3.83 \mathrm{E}-05$ \\
\hline a Datasets available $9 . \mathrm{https} \cdot /$ doi.0rg $10.6071 / \mathrm{M} 3 \mathrm{HW} 93$ & & & & &
\end{tabular}

${ }^{\mathrm{a}}$ Datasets available at: https://doi.org/10.6071/M3HW93. 
Table S37. Alternate container-ship exhaust emissions used in the sensitivity analysis

\begin{tabular}{|c|c|c|c|c|c|c|c|}
\hline $\begin{array}{l}\text { Trip } \\
\text { segment }\end{array}$ & $\mathrm{CO}_{2}$ & $\mathrm{CH}_{4}$ & $\mathrm{~N}_{2} \mathrm{O}$ & $\mathrm{NOx}^{\mathrm{a}}$ & $\mathrm{SOx}^{\mathrm{b}}$ & $\mathrm{BC}$ & $\mathrm{OC}$ \\
\hline \multicolumn{8}{|l|}{$R S Z^{\mathrm{c}, \mathrm{d}}$} \\
\hline $\mathrm{HFO}^{\mathrm{e}, \mathrm{f}}$ & $3.97 \times 10^{-3}$ & $9.81 \times 10^{-8}$ & $1.86 \times 10^{-7}$ & $9.33 \times 10^{-5}$ & $6.75 \times 10^{-5}$ & $5.13 \times 10^{-7}$ & $6.00 \times 10^{-7}$ \\
\hline $\mathrm{MGO}^{\mathrm{f}, \mathrm{g}}$ & $3.97 \times 10^{-3}$ & $9.81 \times 10^{-8}$ & $1.86 \times 10^{-7}$ & $9.33 \times 10^{-5}$ & $3.01 \times 10^{-6}$ & $5.13 \times 10^{-7}$ & $6.00 \times 10^{-7}$ \\
\hline $\mathrm{HFO}^{\mathrm{e}, \mathrm{h}}$ & $5.23 \times 10^{-3}$ & $9.81 \times 10^{-8}$ & $2.53 \times 10^{-7}$ & $1.29 \times 10^{-4}$ & $8.90 \times 10^{-5}$ & $6.76 \times 10^{-7}$ & $7.92 \times 10^{-7}$ \\
\hline $\mathrm{MGO}^{\mathrm{g}, \mathrm{h}}$ & $5.23 \times 10^{-3}$ & $9.81 \times 10^{-8}$ & $2.53 \times 10^{-7}$ & $1.29 \times 10^{-4}$ & $3.86 \times 10^{-6}$ & $6.76 \times 10^{-7}$ & $7.92 \times 10^{-7}$ \\
\hline $\mathrm{HFO}^{\mathrm{i}, \mathrm{j}}$ & $4.47 \times 10^{-3}$ & $9.81 \times 10^{-8}$ & $2.13 \times 10^{-7}$ & $1.08 \times 10^{-4}$ & $1.38 \times 10^{-5}$ & $5.77 \times 10^{-7}$ & $6.76 \times 10^{-7}$ \\
\hline $\mathrm{HFO}^{\mathrm{j}, \mathrm{k}}$ & $4.47 \times 10^{-3}$ & $9.81 \times 10^{-8}$ & $2.13 \times 10^{-7}$ & $1.08 \times 10^{-4}$ & $3.58 \times 10^{-5}$ & $5.77 \times 10^{-7}$ & $6.76 \times 10^{-7}$ \\
\hline $\mathrm{HFO}^{\mathrm{j}, 1}$ & $4.47 \times 10^{-3}$ & $9.81 \times 10^{-8}$ & $2.13 \times 10^{-7}$ & $1.08 \times 10^{-4}$ & $9.64 \times 10^{-5}$ & $5.77 \times 10^{-7}$ & $6.76 \times 10^{-7}$ \\
\hline \multicolumn{8}{|l|}{ Cruise $^{\mathrm{d}}$} \\
\hline $\mathrm{HFO}^{\mathrm{e}, \mathrm{m}}$ & $9.67 \times 10^{-3}$ & $9.01 \times 10^{-8}$ & $4.78 \times 10^{-7}$ & $2.47 \times 10^{-4}$ & $1.65 \times 10^{-4}$ & $1.25 \times 10^{-6}$ & $1.46 \times 10^{-6}$ \\
\hline $\mathrm{MGO}^{\mathrm{g}, \mathrm{m}}$ & $9.67 \times 10^{-3}$ & $9.01 \times 10^{-8}$ & $4.78 \times 10^{-7}$ & $2.47 \times 10^{-4}$ & $6.97 \times 10^{-6}$ & $1.25 \times 10^{-6}$ & $1.46 \times 10^{-6}$ \\
\hline $\mathrm{HFO}^{\mathrm{e}, \mathrm{n}}$ & $1.29 \times 10^{-2}$ & $1.22 \times 10^{-7}$ & $6.41 \times 10^{-7}$ & $3.32 \times 10^{-4}$ & $2.20 \times 10^{-4}$ & $1.67 \times 10^{-6}$ & $1.95 \times 10^{-6}$ \\
\hline $\mathrm{MGO}^{\mathrm{g}, \mathrm{n}}$ & $1.29 \times 10^{-2}$ & $1.22 \times 10^{-7}$ & $6.41 \times 10^{-7}$ & $3.32 \times 10^{-4}$ & $9.27 \times 10^{-6}$ & $1.67 \times 10^{-6}$ & $1.95 \times 10^{-6}$ \\
\hline $\mathrm{HFO}^{\mathrm{i}, \mathrm{o}}$ & $1.11 \times 10^{-2}$ & $1.05 \times 10^{-7}$ & $5.52 \times 10^{-7}$ & $2.85 \times 10^{-4}$ & $3.43 \times 10^{-5}$ & $1.44 \times 10^{-6}$ & $1.69 \times 10^{-6}$ \\
\hline $\mathrm{HFO}^{\mathrm{j,o}}$ & $1.11 \times 10^{-2}$ & $1.05 \times 10^{-7}$ & $5.52 \times 10^{-7}$ & $2.85 \times 10^{-4}$ & $8.93 \times 10^{-5}$ & $1.44 \times 10^{-6}$ & $1.69 \times 10^{-6}$ \\
\hline $\mathrm{HFO}^{\mathrm{j}, \mathrm{o}}$ & $1.11 \times 10^{-2}$ & $1.05 \times 10^{-7}$ & $5.52 \times 10^{-7}$ & $2.85 \times 10^{-4}$ & $2.40 \times 10^{-4}$ & $1.44 \times 10^{-6}$ & $1.69 \times 10^{-6}$ \\
\hline \multicolumn{8}{|l|}{ Hotel $^{\mathrm{p}}$} \\
\hline $\mathrm{HFO}^{\mathrm{e}, \mathrm{q}}$ & $1.01 \times 10^{3}$ & $5.63 \times 10^{-3}$ & $4.36 \times 10^{-2}$ & $2.07 \times 10^{1}$ & $1.72 \times 10^{1}$ & $1.31 \times 10^{-1}$ & $1.53 \times 10^{-1}$ \\
\hline $\mathrm{MGO}^{\mathrm{g}, \mathrm{q}}$ & $1.01 \times 10^{3}$ & $5.63 \times 10^{-3}$ & $4.36 \times 10^{-2}$ & $2.07 \times 10^{1}$ & $8.30 \times 10^{-1}$ & $1.31 \times 10^{-1}$ & $1.53 \times 10^{-1}$ \\
\hline $\mathrm{HFO}^{\mathrm{e}, \mathrm{r}}$ & $1.37 \times 10^{3}$ & $7.62 \times 10^{-3}$ & $5.90 \times 10^{-2}$ & $2.80 \times 10^{1}$ & $2.33 \times 10^{1}$ & $1.77 \times 10^{-1}$ & $2.07 \times 10^{-1}$ \\
\hline $\mathrm{MGO}^{\mathrm{g}, \mathrm{r}}$ & $1.37 \times 10^{3}$ & $7.62 \times 10^{-3}$ & $5.90 \times 10^{-2}$ & $2.80 \times 10^{1}$ & 1.12 & $1.77 \times 10^{-1}$ & $2.07 \times 10^{-1}$ \\
\hline $\mathrm{HFO}^{\mathrm{i}, \mathrm{s}}$ & $1.19 \times 10^{3}$ & $6.62 \times 10^{-3}$ & $5.13 \times 10^{-2}$ & $2.43 \times 10^{1}$ & 6.09 & $1.54 \times 10^{-1}$ & $1.80 \times 10^{-1}$ \\
\hline $\mathrm{HFO}^{\mathrm{k}, \mathrm{s}}$ & $1.19 \times 10^{3}$ & $6.62 \times 10^{-3}$ & $5.13 \times 10^{-2}$ & $2.43 \times 10^{1}$ & $1.58 \times 10^{1}$ & $1.54 \times 10^{-1}$ & $1.80 \times 10^{-1}$ \\
\hline $\mathrm{HFO}^{1, \mathrm{~s}}$ & $1.19 \times 10^{3}$ & $6.62 \times 10^{-3}$ & $5.13 \times 10^{-2}$ & $2.43 \times 10^{1}$ & $4.26 \times 10^{1}$ & $1.54 \times 10^{-1}$ & $1.80 \times 10^{-1}$ \\
\hline
\end{tabular}

\footnotetext{
${ }^{\mathrm{a}} \mathrm{NOx}$ as nitrogen dioxide $\left(\mathrm{NO}_{2}\right)$.

${ }^{\mathrm{b}} \mathrm{SOx}$ as sulfur dioxide $\left(\mathrm{SO}_{2}\right)$.

${ }^{\mathrm{c}}$ Reduced speed zone (RSZ).

${ }^{\mathrm{d}}$ Emission factor given in units kilograms of pollutant per ton-kilometer.

${ }^{\mathrm{e}}$ Heavy fuel oil (HFO) with a fuel sulfur level of 2.4 (\% wt.).

${ }^{\mathrm{f}}$ Container ship speed $16.7 \mathrm{~km} \mathrm{~h}^{-1}$ (9 knots) and a load factor (LF) of 0.064 .

${ }^{\mathrm{g}}$ Marine gas oil (MGO) with a fuel sulfur level of 0.1 (\% wt.).

${ }^{\mathrm{h}}$ Container ship speed $22.2 \mathrm{~km} \mathrm{~h}^{-1}$ (12 knots) and a LF of 0.15 .

${ }^{\mathrm{i}} \mathrm{HFO}$ with a fuel sulfur level of 0.5 (\% wt.).

${ }^{\mathrm{j}}$ Container ship speed $19.4 \mathrm{~km} \mathrm{~h}^{-1}(10.5$ knots $)$ and a LF of 0.10 .

${ }^{\mathrm{k}} \mathrm{HFO}$ with a fuel sulfur level of 1.3 (\% wt.).

${ }^{1} \mathrm{HFO}$ with a fuel sulfur level of 3.5 ( $\%$ wt.).

${ }^{\mathrm{m}}$ Container ship speed $33.3 \mathrm{~km} \mathrm{~h}^{-1}$ (18 knots) and a LF of 0.51 .

${ }^{\mathrm{n}}$ Container ship speed $40.7 \mathrm{~km} \mathrm{~h}^{-1}$ (22 knots) and a LF of 0.81 .

${ }^{\circ}$ Container ship speed $36.1 \mathrm{~km} \mathrm{~h}^{-1}$ (19.5 knots) and a LF of 0.65 .

${ }^{\mathrm{p}}$ Emission factor given in units kilograms of pollutant per hour.

${ }^{\mathrm{q}}$ Auxiliary engine LF of 0.17 .

${ }^{\mathrm{r}}$ Auxiliary engine LF of 0.23 .

${ }^{\mathrm{s}}$ Auxiliary engine LF of 0.20 .
} 